\title{
AVALIAÇÃO CLÍNICA DA EFETIVIDADE DA REMOÇÃO MECÂNICA DE PLACA DENTÁRIA POR DIFERENTES \\ DISPOSITIVOS UTILIZADOS PARA HIGIENE BUCAL EM BEBÊS
}

ANA LUIZA FALAVINHA VIEIRA

\begin{abstract}
Dissertação apresentada à Faculdade de Odontologia de Bauru, da Universidade de São Paulo, como parte dos requisitos para obtenção do título de Mestre em Odontologia, área de Odontopediatria.
\end{abstract}

(Edição Revisada)

BAURU 


\section{AVALIAÇÃO CLÍNICA DA EFETIVIDADE DA REMOÇÃO MECÂNICA DE PLACA DENTÁRIA POR DIFERENTES DISPOSITIVOS UTILIZADOS PARA HIGIENE BUCAL EM BEBÊS}

ANA LUIZA FALAVINHA VIEIRA

Dissertação apresentada à Faculdade de Odontologia de Bauru, da Universidade de São Paulo, como parte dos requisitos para obtenção do título de Mestre em Odontologia, área Odontopediatria.

(Edição Revisada)

Orientadora: $\operatorname{Prof}^{\mathrm{a}} \mathrm{Dr}^{\mathrm{a}}$ Maria Aparecida de Andrade Moreira Machado 


\section{Vieira, Ana Luiza Falavinha}

V673a Avaliação clínica da efetividade de remoção mecânica de placa dentária por diferentes dispositivos utilizados para higiene bucal em bebês/ Ana Luiza Falavinha Vieira - Bauru, 2000.

110p.: $29,7 \mathrm{~cm}$.

Dissertação. (Mestrado) - Faculdade de Odontologia de Bauru. USP.

Orientador: $\operatorname{Prof}^{-a}$ Dr $^{-a}$ Maria Aparecida de Andrade Moreira Machado

Autorizo, exclusivamente para fins acadêmicos e científicos, a reprodução total ou parcial desta dissertação, por processos fotocopiadores e outros meios eletrônicos.

Assinatura do autor:

Data: $18 / 09 / 00$ 


\section{ANA LUIZA FALAVINHA VIEIRA}

18 de dezembro de 1975

Lençóis Paulista - SP

$1994-1997$

$1998-2000$

1999

Associações
Nascimento

Curso de Odontologia - Faculdade de Odontologia de Bauru - Bauru - SP

Curso de Pós-Graduação em Odontopediatria, em nível de Mestrado, na Faculdade de Odontologia de Bauru, USP.

Professora Assistente I da disciplina de Odontopediatria e Ortodontia, na Faculdade de Odontologia da Universidade Paulista, campus Bauru.

APCD - Associação Paulista de Cirurgiões Dentistas

CRO - Conselho Regional de Odontologia IADR - International Association for Dental Research

SBPqO - Sociedade Brasileira de Pesquisa Odontológica 


\section{SUMÁRIO}

LISTA DE ABREVIATURAS ................................................ iii

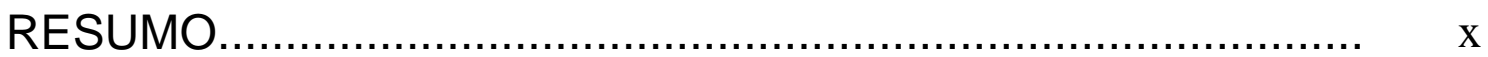

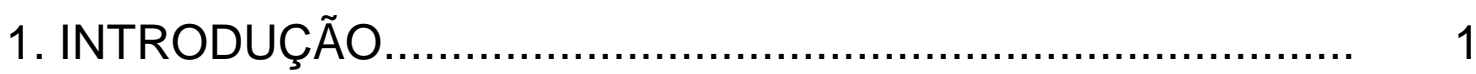

2. REVISÃO DE LITERATURA 6

2. 1-PLACA DENTÁRIA 7

2.1 - PLACA DENTÁRIA....

2.1.1 - Considerações gerais.

2.1.2 - Métodos de avaliação clínica da placa dentária.

2.2 - HIGIENE BUCAL

2.3 - ODONTOLOGIA EM BEBÊS.

2.3.1 - Papel da higiene bucal na prevenção da cárie em bebês.

2.3.2 - Métodos para higiene bucal em bebês.

3. PROPOSIÇÃO ................................................................ 40

4. MATERIAL E MÉTODOS................................................ 42

5. RESULTADOS ............................................................. 56

6. DISCUSSÃO ............................................................. 73

7. CONCLUSÕES........................................................ 85

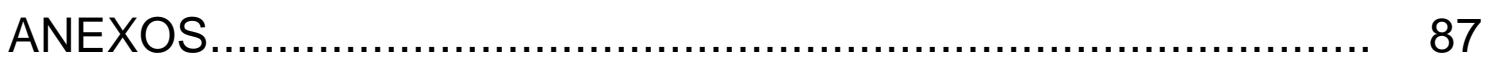

REFERÊNCIAS BIBLIOGRÁFICAS..................................... 94

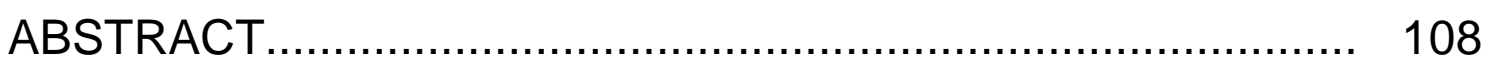




\section{LISTA DE ABREVIATURAS}

cm - Centímetros

d.p. - Desvio padrão

FOB - Faculdade de Odontologia de Bauru

s - Segundos

USP - Universidade de São Paulo 
Agradeço à DEUS, pelo dom da vida, por me presentear com a inteligência e o livre arbítrio, por colocar em minha vida pessoas tão especiais, por todas oportunidades concedidas, por renovar a cada dia minhas forças, para que eu possa transpor os obstáculos que se apresentam em meu caminho e suportar aqueles que são intransponíveis. 
À minha mãe, Lucimar, por sua dedicação, amor, compreensão e incentivo, pelo exemplo de dignidade e honestidade, pela sabedoria e confiança transmitidas, por tentar sempre me mostrar os caminhos certos e torná-los mais suaves, pelo apoio - imprescindível para que eu chegasse até aqui.

Ao meu pai, Jorge, pelo apoio em todos os momentos, pela dedicação e por todos esforços em me proporcionar uma vida feliz.

À minha filha, Laura, um presente de Deus que encheu de alegria minha vida, de quem roubei preciosos momentos de convivência durante a realização deste trabalho e que ainda não consegue compreender o porquê disto tudo, mas que é a razão principal de minhas realizações.

Às minhas irmãs, Carô e Ciça, pelo amor, carinho, compreensão e por cuidarem tão bem da Laura durante minha ausência.

Ao Eduardo, que durante todo este tempo foi muito mais que namorado, foi companheiro, amigo, conselheiro e acima de tudo teve muita paciência...Além de toda a ajuda durante a fase experimental e redação deste . 
Agradeço sinceramente à minha orientadora, Profa. Dra. Maria Aparecida de Andrade Moreira Machado, profissional de extrema competência, pela atenção, ajuda e paciência, fundamentais para a execução deste trabalho. Agradeço ainda pela amizade, pelo incentivo, pelos conhecimentos transmitidos e pela confiança em mim depositada. 


\section{AGRADEÇO ESPECIALMENTE}

À Profa. Dra. Maria Fidela de Lima Navarro, que me iniciou nos caminhos da pesquisa científica, pelas oportunidades concedidas, pela amizade e pelo exemplo de profissional e de ser humano a ser seguido.

Ao Prof. Dr. José Valdes Conti, pela oportunidade de ingresso na carreira docente e pela confiança.

Aos professores da disciplina de Odontopediatria da Faculdade de Odontologia de Bauru, Prof. Dr. Aymar Pavarini, Prof. Dr. Bernardo Gonzalez Vono, Prof. Dr. José Eduardo de Oliveira Lima, Profa. Dra. Maria Francisca Thereza Borro Bijela, Prof. Dr. Ruy César Camargo Abdo, Profa. Dra. Salete Moura Bonifácio da Silva, pela atenção, convívio e conhecimentos transmitidos.

Aos funcionários da disciplina de Odontopediatria da Faculdade de Odontologia de Bauru, Fátima, Kelle, D. Lia, Lilian, Maria Estela, Paulo e D. Wilma, pela amizade, carinho e colaboração em todos os momentos.

Aos funcionários do Berçário e Maternal Leite e Amor, pelo amor e carinho com que cuidaram da Laura, possibilitando que eu continuasse meus estudos. 
Aos amigos do curso de Mestrado, Adriano, Ana Carla, Cleide, Dani, Maria Fernanda, Marina, Lívia, Paloma e Paty. "Cada amigo representa um mundo em nós, que provavelmente não tinha nascido até ele chegar"- Anais Nin.

As colegas da disciplina de Odontopediatria e Ortodontia da UNIP, Ana Cláudia, Daniela, Nildinha e em especial à Lígia, pelas valiosas sugestões.

À Daniela Carmesini Lima Carvalho, que me acompanhou e ajudou muito durante a fase experimental deste trabalho.

Aos pacientes e seus responsáveis, pela colaboração e boa vontade, sem as quais este trabalho se tornaria inviável.

À Sra. Silvia Renata da Silva, diretora da Creche Comunitária "Monteiro Lobato" e à todos os funcionários, pela atenção e colaboração dispensados. 


\section{AGRADEÇO AINDA,}

À Faculdade de Odontologia de Bauru - FOB- da Universidade de São Paulo, através de seu diretor Prof. Dr. Aymar Pavarini e do presidente da comissão de Pós-Graduação Prof. Dr. Luiz Fernando Pegoraro.

Aos funcionários da Faculdade de Odontologia de Bauru, em especial aos da seção de Pós-Graduação, pela orientação, eficiência e atenção e aos da biblioteca, pela dedicação e paciência com que realizam seu trabalho e pela atenção que dispensam a todos os alunos.

Ao Prof. José Roberto Pereira Lauris, pelos ensinamentos e realização da análise estatística deste trabalho.

Ao Conselho Nacional de Desenvolvimento Científico e Tecnológico (CNPq), pela concessão de bolsa de estudos.

E à todos, que direta ou indiretamente contribuíram para realização deste trabalho. 
RESUMO 


\section{RESUMO}

Este trabalho avaliou a efetividade na remoção de placa dentária promovida por cinco dispositivos diferentes: fralda, gaze, escova dental monobloco Científica Baby, escova dental para uso no dedo Infa-Dent e escova dental convencional Dental Prev Baby, que foram testados em todas as crianças do estudo. No total, 63 crianças de 12 a 36 meses de idade participaram do estudo, divididas em 2 grupos, no primeiro grupo as crianças (36) tiveram seus dentes higienizados pelas próprias mães e no outro (27 crianças), um Odontopediatra é que realizava este procedimento. A avaliação foi feita por um único examinador, através dos índices de placa de Quigley; Hein (nas superfícies lisas) e de Mestrinho; Carvalho; Figueiredo (nas superfícies oclusais), realizados antes e após a higiene bucal, após aplicação de solução evidenciadora de placa Verde de Malaquita a $0,6 \%$. Todos os dentes com mais de metade da coroa presentes na cavidade bucal, foram avaliados. Para avaliação dos resultados, os grupos foram subdivididos em: sub-grupo anteriores (bebês apenas com dentes anteriores) e sub-grupo posteriores (bebês que já possuíssem pelo menos 2 dentes posteriores irrompidos). Avaliou-se também o comportamento dos bebês durante a realização da higienização. Os resultados mostraram, em ambos os grupos, que a escova convencional Dental Prev Baby foi o dispositivo mais efetivo na remoção de placa bacteriana. Para o sub-grupo anteriores, também observouse uma remoção semelhante a da escova convencional através da utilização da gaze e fralda. A menor quantidade de placa removida foi obtida quando da utilização da dedeira Infa-Dent. A higienização realizada pelo Odontopediatra 
se mostrou mais eficaz do que a realizada pelas mães. Quanto ao comportamento, não houve diferença estatisticamente significante entre os dispositivos utilizados, mas observou-se uma melhora no mesmo ao longo das sessões. A partir da metodologia empregada pode-se concluir que: apesar de métodos alternativos como a fralda e a gaze serem efetivos para bebês que possuam apenas dentes anteriores, a escova convencional se apresentou mais efetiva em ambos os grupos. 


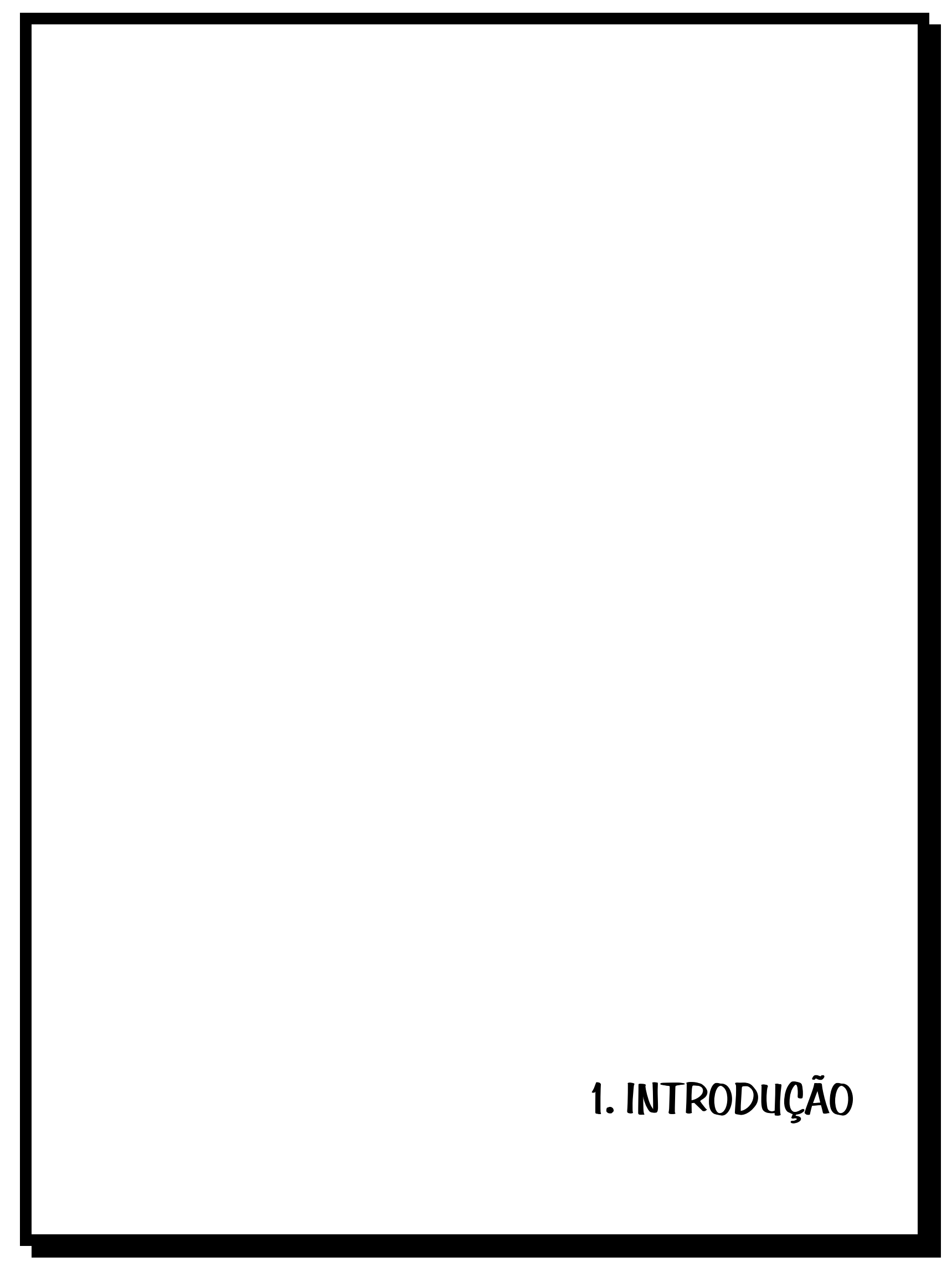




\section{INTRODUÇÃO}

A Odontologia atual se encontra na era da promoção de saúde. Segundo essa concepção de Odontologia, os cirurgiões dentistas tem como dever contribuir para a qualidade total de vida de seus pacientes, ou seja, garantir através de todos os meios existentes e disponíveis uma cavidade bucal saudável. E nada existe de mais simples, econômico e confortável para atingirmos tais objetivos do que a prevenção das doenças bucais, já que o mecanismo curativo envolve processos mais avançados, não adequadamente efetivos e em muito casos, facilitando a recorrência da doença ${ }^{55}$. Além destes fatores irreversíveis existe o fator financeiro, acentuadamente superior em condições curativas, que dificulta o acesso à maioria dos indivíduos, pelo menos ao que se refere à realidade brasileira.

Novos conhecimentos sobre o processo saúde-doença bucal, apoiados em estudos epidemiológicos ${ }^{11,44,52}$ demonstram claramente a necessidade de atuação odontológica precoce quando pretende-se trabalhar com a manutenção da saúde e a prevenção das doenças bucais. Tendo em vista a ocorrência da irrupção dos primeiros dentes, da colonização da cavidade bucal por bactérias, da instalação dos hábitos básicos no primeiro ano de vida, pode se dizer que esse período tem extrema importância para a saúde bucal futura dos indivíduos ${ }^{1}$. Dentro deste contexto, a Odontopediatria é uma especialidade privilegiada, pois nenhuma outra tem a possibilidade de exercer esse papel preventivo antes mesmo do paciente vir ao mundo, através da Odontologia 
Pré-Natal, que tem por objetivo orientar a gestante sobre a importância de receber o bebê com a cavidade bucal saudável, e ainda da Odontologia em Bebês, que inicia o trabalho preventivo educativo antes que o primeiro dente irrompa na cavidade bucal.

O impacto de ações bem sucedidas na primeira infância influenciarão positivamente o padrão de saúde bucal durante toda a vida do indivíduo, por outro lado, hábitos inadequados durante os primeiros anos de vida apresentarão grande dificuldade de modificação no futuro. Assim, tendo como base ações educativas e preventivas torna-se viável a modificação dos hábitos de saúde bucal no núcleo familiar a partir de ações voltadas para as necessidades específicas do bebê ${ }^{94}$.

Dentre as patologias que acometem a boca a cárie dentária ainda se mostra, no Brasil e em muitos outros países, a de maior prevalência. Apesar de todos esforços voltados à manutenção da saúde bucal em crianças, muitos ainda são acometidos por essa patologia. Definida como uma doença infecciosa e transmissível, que causa a destruição localizada dos tecidos dentais duros por ácidos produzidos por bactérias presentes nos depósitos aderidos ao dente ${ }^{84}$, é considerada como de etiologia multifatorial, decorrente da interação dos fatores hospedeiro, microbiota e substrato durante um determinado tempo ${ }^{54}$. Portanto a prevenção só é alcançada através do controle destes fatores.

A identificação do risco do desenvolvimento de cárie em crianças, baseia-se em informações sobre a combinação de fatores sociodemográficos, dieta, higiene bucal e contaminação por estreptococos do grupo mutans ${ }^{43}$. Já é clara a existência de uma relação direta entre hábitos alimentares inadequados 
e higiene bucal deficiente, resultando no aparecimento de lesões de cárie ${ }^{95}$, sendo que a presença de placa dentária visível nos incisivos é considerada um fator predictivo de cárie em bebês ${ }^{1,44}$. Portanto o controle adequado da placa dentária torna-se um recurso importante, talvez o mais poderoso, na prevenção da cárie dentária.

A remoção da placa pode ser feita através de meios químico e/ou mecânico, sendo este último mais utilizado para a manutenção da saúde dos dentes e gengivas ${ }^{7,41}$. Este tipo de controle é uma medida preventiva amplamente usada, podendo ser realizado tanto pelo paciente, quanto pelo profissional (profilaxia profissional) ${ }^{13,16,48}$.

O controle mecânico da placa realizado pelo próprio paciente, e no caso de crianças menores por seus responsáveis, é chamado de higiene bucal. Em bebês essa higiene é muito importante tendo em vista que se este hábito ocorrer precocemente (tão logo irrompa o primeiro dente), há um aumento na probabilidade da criança apresentar-se livre de cárie aos 3 anos de idade ${ }^{13}$. Desta forma, a informação e educação quanto à importância desse hábito e a motivação dos pais para que coloquem-no em prática o mais cedo possível se torna imprescindível.

As maneiras existentes de se realizar a higiene bucal nessa faixa etária são muitas e variam de acordo com as diferentes filosofias existentes. Cabe ao profissional, além de educar e treinar os responsáveis para o controle da placa, selecionar instrumentos a serem por eles utilizados para este fim. Atualmente, encontra-se disponível no mercado uma grande diversidade de produtos para higiene bucal especialmente desenvolvidos para estes pacientes e a seleção 
dos diferentes meios de limpeza deve sempre considerar as necessidades individuais de cada paciente ${ }^{13}$ e sobretudo sua eficácia.

Tendo em vista a importância do controle da placa bacteriana em idade precoce para a saúde bucal da criança, a variedade de produtos com esta finalidade e o pequeno número de trabalhos publicados na literatura a respeito de dispositivos específicos para higienização da cavidade bucal de bebês, nos pareceu pertinente avaliar alguns dos que rotineiramente são indicados por cirurgiões dentistas e mais especificamente por odontopediatras e assim disponibilizar dados que poderão ajudar tais profissionais e pais, na escolha do mais efetivo. 
2. REVISÃO DE LITERATURA 


\section{REVISÃO DE LITERATURA}

\section{1 - Placa dentária}

\subsubsection{Considerações gerais}

GIBBONS; VAN HOUTE $(1973)^{23}$ afirmaram que a placa dentária pode ser considerada como uma massa bacteriana densa, não-calcificada, tão firmemente aderida à superfície dentária que resiste ao fluxo salivar constante. A formação da placa em um dente limpo, inicialmente envolve a aderência de bactérias à película adquirida. Posteriormente novas bactérias vão se agregando as outras previamente aderidas ao dente, devido a existência de interações adesivas entre as bactérias que são mediadas por materiais da matriz da placa. E finalmente as bactérias se reproduzem.

Em 1976, THELAIDE; THELAIDE ${ }^{81}$ definiram placa como uma massa mole concentrada, constituída principalmente por uma grande variedade de bactérias unidas entre si em uma substância inter-microbiana. Os autores também consideram estar estabelecido que a placa é um pré-requisito para a cárie.

Em 1970, O'LEARY58 chamou a atenção para o fato de que, clinicamente, é raro haver ausência completa de placa em todas as superfícies dentárias após o uso de soluções reveladoras. Concluiu daí que é provável que todo indivíduo tenha um nível de placa compatível com a saúde clínica dos tecidos bucais, classificando este tipo de entidade como placa compatível. 
Em pesquisa sobre correlação entre higiene bucal e saúde dentária, RIPA et al. (1977) ${ }^{67}$ concluíram que a placa pode ser cariogênica ou não cariogênica. Tem sido reconhecido que o potencial cariogênico da placa é determinado pelos tipos de microorganismos que a compõe, assim como da disponibilidade de substratos bacterianos adequados.

MINAH; LOESHE $(1977)^{50}$, estudaram o metabolismo da sacarose por microorganismos da placa dentária cariogênica e não-cariogênica. Foi encontrado que o $S$. mutans, que se apresenta em altos níveis na placa cariogênica, utiliza a sacarose rapidamente, formando ácido láctico, polissacarídeo intracelular, glucano extracelular insolúvel. Já a espécie Actinmyces, abundante na placa não cariogênica, usa a sacarose mais lentamente, formando ácidos mais voláteis do que o $S$. mutans.

HOLMEN et al. (1985) ${ }^{34}$ estudaram durante períodos controlados, por 4 semanas, as reações do esmalte in vivo sem a remoção mecânica ou desorganização da placa dentária. Foi verificado que após 4 semanas com a placa intacta já é possível observar mudanças macroscópicas (sem a secagem com ar) no esmalte, ou seja presença de mancha branca. Dando continuidade ao estudo anterior, HOLMEN; THYLSTRUP; ARTUN (1987) ${ }^{35}$, desenvolveram um trabalho com os mesmos dentes, no qual estes foram submetidos à higiene bucal e ao atrito funcional durante até 3 semanas, e observaram que houve paralisação das lesões devido à desorganização e remoção dos depósitos bacterianos.

THYLSTRUP; BRUUN; HOLMEN $(1994)^{83}$ revisando os estudos in vivo sobre os mecanismos iniciais e de paralisação da cárie, relataram que a eliminação total ou parcial das forças mecânicas intra-bucais, que operam durante a mastigação e escovação, permitem a evolução da placa cariogênica, 
resultando em cárie incipiente localizada. Por outro lado, a re-exposição a essas forças mecânicas não apenas paralisam as lesões, mas também permitem sua regressão. Isto ocorre devido a remoção mecânica da placa cariogênica que fica fisicamente interrelacionada com a lesão no esmalte.

FEJERSKOV $(1997)^{20}$, afirmou que ninguém pode discordar do velho conceito "um dente limpo nunca se tornará cariado", pois estudos em humanos têm mostrado que os depósitos microbianos na superfície dos dentes causa lesão de cárie, e em uma velocidade rápida, quando a sacarose é metabolizada. Segundo o autor, a cárie é uma doença multifatorial, mas a placa dentária é sua única causa.

BLINKHORN $(1998)^{9}$, refletindo sobre educação em saúde bucal, concluiu ser a prevenção a chave para solucionar a maioria dos problemas bucais. Segundo o autor, tratamentos curativos são apenas paliativos, pois não resolvem o problema. Para ele precisamos nos lembrar que os dois principais problemas na Odontologia - cárie dentária e doença periodontal - são de origem bacteriana, ou seja, ocorrem em função da placa dentária, e são exacerbados pela dieta inadequada, remoção ineficaz da placa e flúor em quantidades não ideais. Com base nisso, a educação da população com o intuito de promoção de saúde bucal deve ser um dos instrumentos usado não só pelos cirurgiões-dentistas como também por outros profissionais de saúde, tais como médicos pediatras e obstetras. Para que resultados desta ação possam ser observados, caberá aos cirurgiões-dentistas monitorá-las junto à comunidade. 


\subsubsection{Métodos de avaliação clínica da placa dentária}

As pesquisas sobre placa dentária, geralmente empregam métodos quantitativos para sua avaliação através de diversos índices, que se traduzem em valores numéricos denominados escores.

GREENE; VERMILLION (1960) $)^{28}$ propuseram um método para avaliar a higiene bucal quantitativamente. Esse método seria útil para estudar a epidemiologia da doença periodontal, para avaliar a eficiência da escovação e a prática de hábitos bucais saudáveis por uma determinada população. Índice de Higiene Bucal (IHB) foi o nome atribuído à este método, que compreende o índice de placa e o índice de cálculo. Os dentes são avaliados em suas faces vestibular e lingual, sendo que os selecionados para tal são os seguintes: o dente superior mais posterior tanto do lado direito quanto do lado esquerdo, dente anterior superior, repetidos os mesmos dentes para o arco inferior. Só são considerados aqueles que estiverem totalmente irrompidos, isto é, quando a face oclusal ou incisal tiver alcançado o plano oclusal, e a avaliação é feita passando-se um explorador $n^{0} 5$ pela face em questão. Os escores utilizados para classificar o dente são (Fig. 1):

$$
\begin{aligned}
& 0 \text { - sem placa } \\
& 1 \text { - placa em até } 1 / 3 \\
& \text { da superfície } \\
& 2 \text { - placa em até } 2 / 3 \\
& \text { da superfície } \\
& 3 \text { - placa em mais de } \\
& \text { 2/3 da superfície }
\end{aligned}
$$

FIGURA 1 - Diagrama mostrando a variação da quantidade de placa de acordo com os escores 
Segundo os autores, este índice pareceu ser um método sensível e simples para acessar a higiene bucal.

Em estudo comparando a eficiência de limpeza de uma escova dentária manual e uma escova elétrica, QUIGLEY; HEIN (1962) ${ }^{65}$ propuseram um método para avaliar esta limpeza. Os sujeitos da amostra bochechavam com solução evidenciadora de placa e as superfícies vestibular e lingual de todos os dentes eram avaliadas segundo o esquema de escores a seguir (Fig. 2):

$$
\begin{aligned}
& 0 \text { - sem placa } \\
& 1 \text { - pequenos pontos de placa isolados na } \\
& \text { margem gengival } \\
& 2 \text { - linha definida de placa na margem } \\
& \text { gengival } \\
& 3 \text { - placa no terço gengival da superfície } \\
& 4 \text { - placa em até } 2 / 3 \text { da superfície } \\
& 5 \text { - placa em mais de } 2 / 3 \text { da superfície }
\end{aligned}
$$

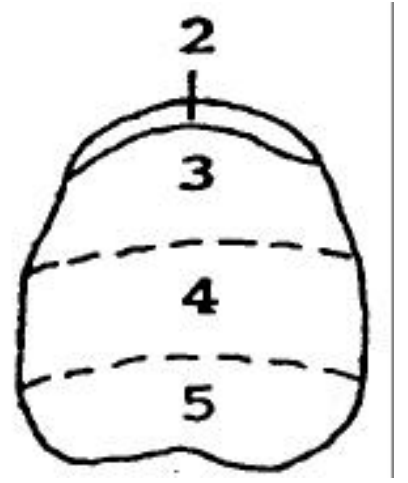

FIGURA 2 - Divisão do dente para a classificação em escores

Após a realização da escovação, as superfícies eram novamente avaliadas. O índice final era calculado pela soma dos escores de todas as superfícies, dividido pelo número de superfícies examinadas.

Em 1964, GRENNE; VERMILLION²9 tentando tornar mais rápido e simples o Índice de Higiene Bucal (IHB) criado pelos próprios autores em 1960, testaram o Índice de Higiene Bucal Simplificado (IHB-S). Este índice consistia em examinar 6 superfícies (superfície vestibular de 1 molar superiores esquerdo e direito, do incisivo central superior direito e do incisivo central inferior esquerdo e superfície lingual de 1 molar inferior esquerdo e direito) ao invés das 12 preconizadas anteriormente. Como conclusão, os autores descrevem este índice menos sensível que o antecessor, mas como um método rápido para avaliar a limpeza bucal da população. 
Avaliando a distribuição e características da placa dentária em gestantes, SILNESS; LÖE $(1964)^{76}$ utilizaram um índice que avaliava os seguintes dentes: $1^{\underline{0}}$ Molar direito, Incisivo lateral direito e $1^{\mathrm{O}}$ Pré-molar esquerdo na maxila e $1^{\circ}$ Molar esquerdo, Incisivo lateral esquerdo e $1^{\circ}$ Prémolar direito na mandíbula. Em cada dente, as faces vestibular, lingual, mesial e distal eram examinadas de acordo com os seguintes escores:

0 - sem placa

1 - filme de placa aderido a margem gengival, visto apenas após evidenciação ou através do uso de sonda exploradora

2 - moderado acúmulo de placa visível à olho nú na bolsa ou no dente e margem gengival

3 - abundância de placa na bolsa e/ou no dente e margem gengival

Os autores sugeriram que a higiene bucal é adequadamente expressa pela presença e quantidade de placa (Índice de placa).

PODSHADLEY; HALEY ${ }^{64}$ em 1968, desenvolveram o "Patient Hygiene Performance Index" (PHP) que consiste na realização do exame bucal com espelho clínico das superfícies selecionadas (face vestibular do $1^{0}$ molar superior direito, incisivo central superior direito, $1^{\circ}$ molar superior direito, incisivo central inferior esquerdo e face lingual do $1^{0}$ molar inferior direito e $1^{0}$ molar inferior esquerdo) após os dentes entrarem em contato com substância reveladora de placa. Para anotar o escore em cada superfície, o examinador divide o dente em 5 partes (Fig. 3). A coroa clínica é dividida longitudinalmente em terço mesial (D), mediano e distal (E), e o terço mediano é subdividido horizontalmente em terço gengival $(A)$, médio $(B)$ e oclusal $(C)$, gerando cinco áreas a serem consideradas. Para cada uma dessas áreas é atribuído o valor: 


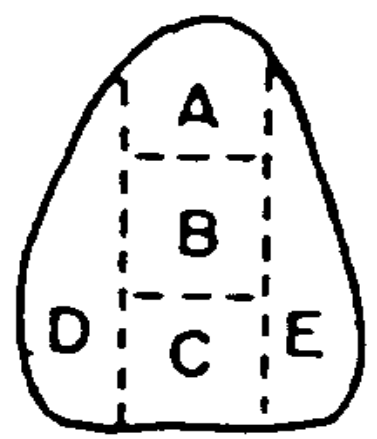

0 - se não há presença de placa

1 - quando a placa está presente.

FIGURA 3 - Divisão da face do dente em 5 áreas

O escore de cada dente é representado pela soma dos valores de cada uma das 5 áreas. Assim, o maior escore atribuído a um dente é 5, e o menor é 0. O grau de desempenho da higiene bucal do paciente é calculado pela soma dos escores dividida pelo número de superfícies examinadas.

O'LEARY, DRAKE; NAYLOR (1972) ${ }^{57}$ propuseram um método de avaliar a placa que permitia uma visão da sua presença nas superfícies individuais dos dentes. Nesse método todas as faces de todos os dentes presentes eram avaliadas quanto a ausência ou presença de placa e não quanto à sua quantidade. Para os autores, esse é um método que permite aos pacientes avaliar seu aprendizado em controlar a placa dentária através da escovação.

Com o intuito de conseguir um meio mais fiel e real da quantidade de placa depositada nos dentes, TOVO ${ }^{87}$ em 1968/1969, comparou o Índice de Higiene Bucal de Greene e Vermillion obtidos com e sem o uso de solução evidenciadora de placa, e concluiu face aos resultados encontrados, que o uso de corantes reveladores deve ser indicado, tanto para levantamento de índices de placa dentária, bem como para identificação de extensão dos mesmos a fim de serem removidos e também com a finalidade de educar os pacientes para uma boa higiene oral. 
RIPA et al. (1977) ${ }^{67}$ concluíram que métodos clínicos de avaliação de placa dentária, como é o caso dos diferentes índices existentes, determinam somente a presença ou distribuição da placa e não podem discriminar os efeitos clínicos dos diferentes tipos de placa, a qual pode ser altamente cariogênica ou não cariogênica.

Para avaliação da placa dentária em bebês, a maioria dos pesquisadores utiliza o método preconizado por ALALUUSUA; MALMIVIRTA ${ }^{1}$ em 1994, que consiste na inspeção visual, sem a utilização de substância evidenciadora, nas superfícies vestibulares dos incisivos maxilares. Este método classifica a placa apenas como ausente ou presente.

\section{2 - Higiene bucal}

Estudando vários aspectos da higiene bucal, SUOMI et al. (1972) ${ }^{80}$ afirmaram que a escovação é o procedimento comumente recomendado para remoção de placa dentária.

Estudando a relação entre idade e tempo gasto na realização de higiene bucal por crianças, PINKHAM $(1975)^{63}$, encontrou não haver relação entre o grau de limpeza e o tempo gasto para tal procedimento em qualquer idade.

Tendo como base a placa dentária ser um pré-requisito para 0 desenvolvimento da cárie, BELLINI, ARNEBERG; VON DER FEHR $(1981)^{5}$ resolveram revisar a relação entre higiene bucal e cárie e concluíram que para a prevenção da mesma a qualidade da limpeza dental é mais importante do que sua prática diária.

KOLMAKOW; NYYSSONEN; HONKALA (1984) ${ }^{39}$ avaliaram o efeito da escovação e do consumo de doces na ocorrência de desmineralização localizada do esmalte dental (mancha branca). Para isso foram examinados 
1.125 dentes de 41 crianças de 14 anos. O diagnóstico foi feito através de transiluminação por fibra ótica (FOTI) e utilização do corante azul de metileno a 2\%. Dados referentes ao consumo de açúcar e freqüência de escovação foram colhidos através de um questionário. A presença de desmineralização localizada foi encontrada em $90 \%$ da crianças e em $33 \%$ dos dentes avaliados, havendo uma maior prevalência entre os meninos. As meninas apresentaram maior freqüência de escovação. A ocorrência da desmineralização localizada diminuiu com o aumento da freqüência de escovação e também com a diminuição da freqüência do consumo de doces. A associação entre a desmineralização focal e a freqüência de escovação sugere que seja este o motivo pelo qual os meninos apresentam maior quantidade de lesões de mancha branca.

STECKSÉN-BLICKS; GUSTAFSSON $(1986)^{78}$ estudaram o impacto de higiene bucal e o uso de flúor no incremento de cárie em 171 crianças de 8 e 13 anos de idade, durante 1 ano. As crianças com um baixo incremento de cárie (0-2 superfícies), mostraram ter menor número de refeições diárias, menor número de $S$. mutans na saliva, menor consumo de sacarose, maior freqüência de higiene bucal e do uso de flúor. Os resultados do trabalho sustentam a importância de uma boa higiene bucal na prevenção da cárie.

SANTOS et al. (1990) ${ }^{72}$ verificaram em crianças de 4 a 6 anos, somente com dentes decíduos e sem uma técnica de escovação determinada, que um tempo de escovação de 3 minutos foi insuficiente para esta faixa etária. Já num tempo de 5 minutos, $70 \%$ da placa dentária foi removida, sem provocar qualquer dano ao tecido gengival. Com os tempos de 8 e 10 minutos, houve 
hiperemia, sangramento ou descamação epitelial, sem diferença estatisticamente significante na efetividade da escovação.

Tentando estabelecer parâmetros para um guia sobre higiene bucal em crianças pré-escolares (0 a 6 anos de idade), OGASAWARA; WATANABE; KASAHARA (1992) ${ }^{56}$ avaliaram a habilidade destas em aprender a escovar seus dentes. Eles classificaram as crianças abaixo de 1 ano e 6 meses de idade no nível "não podem escovar", neste estágio, as crianças não podem compreender o que significa escovar os dentes. As crianças entre 1 ano e 6 meses e 3 anos e 6 meses de idade se tornam hábeis a aprender técnicas de escovação, mas somente aos 6 anos de idade é que a criança têm habilidade para escovar todas as regiões da boca.

Para KWON; GUEDES-PINTO (1995) ${ }^{42}$, as funções e efeitos básicos da escovação dentária são:

- Remover os depósitos de restos alimentares nos dentes, o acúmulo de microorganismos e recentes indultos supragengivais não calcificados.

- Suave massagem gengival, para promover melhor circulação sangüínea e adequada queratinização do epitélio.

- Não irritar ou dilacerar o tecido gengival.

Segundo DUARTE; LOTUFO (1997) ${ }^{17}$, as características físico-químicas da placa fazem com que haja grande dificuldade na remoção mecânica da mesma, no entanto, trabalhos experimentais mostram que esta é a maneira mais eficiente de prevenção tanto das doenças periodontais quanto da cárie dentária. Segundo os mesmos, não há na atualidade, recurso mais seguro para controle da placa dentária do que a escova e o fio dental.

Com o objetivo de analisar 16 escovas encontradas no mercado, MESTRINHO; CARVALHO; FIGUEIREDO $(1994)^{48}$ realizaram um estudo com 8 crianças de 4 a 6 anos de idade, com índice ceos igual a zero. 48 horas antes 
do experimento, os pais eram instruídos a não realizar escovação nos dentes de seus filhos. O registro da placa era feito antes e depois da escovação profissional, com o auxílio de uma solução evidenciadora. A escovação era realizada durante 2 minutos, pelo método de Bass modificado, sem o uso de dentifrício. Em cada sessão eram testadas 4 escovas diferentes por criança, 1 em cada hemi-arco dentário. Ao fim de 4 sessões semanais todas as escovas foram testadas em todas as crianças. Os resultados mostraram não haver diferença significativa entre os diversos tipos de escova testados quanto à remoção de placa bacteriana e que mesmo a escovação profissional não removeu toda a placa das superfícies dentárias.

Em 1996, CLAYDON; ADDY ${ }^{14}$ compararam a remoção de placa por 4 diferentes escovas dentais. 36 voluntários participaram do estudo, e todos eles testaram as 4 escovas. A remoção de placa pelas diferentes escovas não mostraram diferença estatisticamente significantes. O autor conclui que não existem dados que demonstrem inequivocamente que uma escova manual seja superior a qualquer outra no que diz respeito a remoção de placa.

Segundo CURTIS et al. $(1957)^{15}$ até aquele momento a escova dentária tinha sido apontada como o método mais eficiente para controlar a placa bacteriana e para a manutenção da saúde gengival, porém não havia definição sobre qual a técnica mais eficiente.

STARKLEY $(1961)^{77}$ relatou que a técnica de escovação para crianças muito pequenas deveria ser a horizontal e executada pelos pais. Também recomendou a escovação logo após as refeições.

McCLURE ${ }^{45}$, em 1966, pesquisou a melhor técnica de escovação para crianças de 3 a 5 anos de idade. Foram testadas as técnicas Circular e Horizontal, realizadas pelas próprias crianças e pelos seus pais. O método de 
avaliação foi a evidenciação da placa remanescente após a escovação e anotação dos sítios com placa. Com a avaliação dos resultados o autor pode concluir que as crianças dessa faixa etária são completamente incapazes de realizar a escovação dental e que a técnica da esfregadura horizontal foi a mais efetiva, tanto quando os pais como quando as crianças escovavam.

Com o objetivo de comparar o efeito da remoção de placa pela escovação dental controlada através das técnicas Circular e Horizontal, SANGNES; ZACHRISSON; GJERMO (1972) ${ }^{70}$ avaliaram 41 crianças de 5 anos, com a dentição decídua completa, que tiveram seus dentes escovados por higienistas. Os resultados indicaram que a técnica Horizontal foi mais eficiente do que a técnica dos círculos. Segundo os autores, uma das possíveis explicações para esse fato seria que a técnica de círculos requer mais tempo para a mudança da escova de lugar e a técnica horizontal mantém a escova em atividade o tempo todo.

JANNIS (1974) ${ }^{37}$ estudou clinicamente duas técnicas de escovação, a de Stilman modificada e a Horizontal, concluindo não haver diferenças estatisticamente significantes entre ambas, com relação à remoção da placa bacteriana. As duas técnicas parecem ser mais eficientes na região ânterosuperior do que nas regiões posteriores, também pareceu ser mais eficiente nas faces vestibulares do que nas faces linguais.

\section{3 - Odontologia em bebês}

Apesar de PEREIRA, 1929 e BARROS, $1934^{22}$ no início do século mostrarem preocupação com a saúde bucal do bebê, durante muitas décadas a atenção odontológica ao bebê limitou-se à resolução de situações emergenciais associadas a traumatismos dentários ou danos causados pela 
cárie, especialmente a cárie de mamadeira, hoje chamada de cárie precoce da infância (TINANOFF, 1998) ${ }^{85}$. Felizmente, atualmente o enfoque da odontologia está voltado à prevenção das doenças bucais, e esta abordagem fez com que a atenção odontológica ao bebê seja uma condição fundamental para a prática de uma odontologia que visa a promoção de saúde bucal.

Uma prova disso é o relato de WALTER; NAKAMA (1992) ${ }^{95}$ que mostra que em 1985, quando se iniciou o atendimento na Bebê-Clínica da Universidade Estadual de Londrina, $78 \%$ das crianças eram trazidas para receber tratamento curativo e somente $22 \%$ para receber tratamento educativo e preventivo. Já em 1990, com a evolução do conceito de atenção precoce e conscientização da população, apenas $15 \%$ dos bebês eram trazidos à procura de tratamento enquanto $85 \%$ estavam à procura de orientação e prevenção.

A experiência de GOEPFERED $(1987)^{25}$ também foi relatada como muito positiva. Segundo o autor, que foi o mentor do programa de saúde bucal infantil da Universidade de lowa iniciado em 1984, tal programa foi implementado devido aos seguintes fatores: existência da cárie de mamadeira, estabelecimento de hábitos básicos muito precocemente (alimentares, de higiene), sucesso de dentistas em promover crianças sem cáries quando a decisão preventiva é precoce, falta do conhecimento público dos benefícios da prevenção precoce, disponibilidade de fortes evidencias empíricas dos benefícios da atenção odontológica precoce. As visitas eram baseadas em aconselhamento sobre alimentação infantil correta, limpeza bucal e uso do flúor. O bebê também era examinado e a limpeza bucal realizada pelos profissionais que orientavam quanto à técnica e posição a serem adotadas em casa. Posteriormente os pais eram convidados a repetir o procedimento sob supervisão do dentista que oferecia ajuda e sugestões quando necessário. 
Com a avaliação do programa, notou-se que nos primeiros 6 meses de funcionamento havia uma demanda maior de crianças entre 18 e 30 meses mas que logo foi substituída por uma grande quantidade de crianças de 8 a 15 meses de idade. Após o acompanhamento de 18 meses deste trabalho, o autor conclui ser de extrema importância para a prevenção das doenças bucais que os cirurgiões dentistas incentivem a primeira visita odontológica entre os 6 e 12 meses e disponibilizem este serviço preventivo à esses pacientes.

Acreditando na importância do desenvolvimento de hábitos bucais saudáveis precocemente na infância, BLINKHORN (1980) ${ }^{10}$ estudou os fatores que influenciam a transmissão de hábito de higiene bucal pelas mães à suas crianças em idade pré-escolar. Os resultados mostraram que apenas $20 \%$ das mães tinham conhecimento de como cuidar dos dentes de seus filhos e que diferenças sociais não são barreiras para educação efetiva sobre saúde bucal. Segundo o autor, os dentistas têm papel fundamental quando o assunto é aumentar o conhecimento das mães nesse sentido.

Em 1991, $\mathrm{KAMP}^{38}$ apresentou os dados relativos ao primeiro exame de 379 pacientes de até quatro anos de idade que estavam iniciando sua participação em um programa de atenção odontológica precoce. A atividade de cárie encontrada para esta população foi de 8,9\% e o ceod foi de 0,25. Cárie de mamadeira foi encontrada em $5,3 \%$ da população e representou $58,8 \%$ de todas as cárie reportadas. Segundo o autor, estes dados fortalecem a visão de que o aconselhamento sobre saúde bucal deve começar entre 6 meses (ao irromper o primeiro dente) e no máximo 1 ano de idade, pois assim é possível focar a atenção dos pais na futura saúde bucal de seus filhos.

Segundo NAVIA $(1994)^{53}$, a prevenção de cáries em bebês e crianças pequenas não só reduz a doença na dentição decídua, mas também 
estabelece condições, práticas e conhecimentos de saúde bucal que podem garantir que a dentição subsequente se torne realmente a dentição permanente. Para que isso realmente aconteça devemos encarar a cárie como uma doença multifatorial placa-dependente e criar programas preventivos baseados em modificação comportamental, higiene bucal, redução da exposição ao açúcar e uso de flúor.

Discutindo a intervenção bucal precoce, NOWAK; CASAMASSIMO $(1995)^{55}$ consideram que a realização desse procedimento, com bebês e seus pais de uma maneira individualizada, possa ser a próxima fronteira na redução da cárie dental. Além de prevenir cáries, o dentista tem condições de identificar problemas gerais do desenvolvimento, doenças hereditárias e alterações de fala e de linguagem.

MILANEZ; WALTER $(1997)^{49}$ buscaram correlacionar a presença de placa nos incisivos superiores, cárie dentária e atenção odontológica precoce. A amostra envolveu 70 crianças entre 18 e 40 meses, das quais um grupo recebia atenção odontológica precoce e outro não. Os resultados demonstraram diferença estatisticamente significante entre os dois grupos tanto para a presença de placa quanto para a presença de cárie. No grupo que recebia atenção odontológica, 25,7\% das crianças apresentavam placa visível e 2,85\% lesões de cárie. No outro grupo ,sem atenção odontológica, estes percentuais subiam para $68,57 \%$ e $25,71 \%$ respectivamente. Os autores concluíram que a ausência de atendimento odontológico precoce esteve associada com a presença de placa e cárie, o que pareceu demonstrar que a placa visível é um indicativo de risco à cárie. Foi ressaltada a importância do atendimento precoce, principalmente por meio da educação dos pais sobre hábitos de higiene dental no sentido de promover a saúde bucal da criança. 
GARBOZA; WALTER (1997) ${ }^{22}$ estudaram a prevalência de cárie em uma população de 0 - 5 anos atendida precocemente pela Bebê-Clínica da Universidade Estadual de Londrina. Antes da primeira consulta, foi constatado que a população encontrava-se com grande risco de desenvolver cárie, pois $88,81 \%$ tinham o hábito de aleitamento noturno e $81 \%$ não realizavam higiene dental. Após a primeira consulta, na qual foram dadas aos pais as devidas orientações sobre o hábito de aleitamento noturno e higiene bucal, a prevalência de cárie para a população estudada foi baixa, tanto para cárie de mamadeira $(0 \%)$ quanto para cárie simples $(2 \%)$. Tais resultados permitiram aos autores concluir que o atendimento precoce, a educação e conscientização dos pais são eficazes para promoção de saúde bucal nessa faixa etária.

WANDERA (1998) ${ }^{96}$ acredita que todos os dentistas deveriam oferecer programas de saúde bucal para bebês. Segundo ela, o atendimento odontológico preventivo regular é um fator protetor significante contra cáries e melhora consideravelmente o comportamento e a saúde bucal.

FRITSCHER; ARAUJO; FIGUEIREDO (1998) $)^{21}$ avaliando comparativamente os índices de cárie, placa visível e sangramento gengival de 50 pares mãe-filho, encontraram que $50 \%$ das crianças não recebiam nenhum tipo de higienização bucal e que $32 \%$ das mães utilizavam a mesma escova dental tanto para a própria higiene quanto para a do filho. Os autores concluíram que a Odontologia deve voltar-se para a educação e os cuidados preventivos, principalmente para gestantes e bebês.

BLEN; NARENDRAN; JONES (1999) ${ }^{8}$ estudando o índice de cárie em crianças abaixo de 3 anos, atendidas na clínica odontológica na Universidade do Texas, constataram que aproximadamente 2/3 da população entre 25-36 meses, necessitavam de tratamento restaurador, e que essa alta porcentagem 
podia ser atribuída ao uso prolongado da mamadeira, dieta inadequada e higiene bucal deficiente, ou seja, havia falta de educação sobre saúde bucal. Consequentemente, os autores concluíram que a principal responsabilidade do cirurgião-dentista é a prevenção, que começa ao irromper do primeiro dente. Para os autores, uma forma de promover o conhecimento sobre saúde bucal é dar orientações não somente aos pais e responsáveis, mas também aos colegas pediatras e médicos de outras especialidades.

A AMERICAN ACADEMY OF PEDIATRIC DENTISTRY (1999) ${ }^{2}$, recomenda que o cuidado com a saúde bucal do bebê deve começar idealmente com o aconselhamento pré-natal aos pais. O atendimento precoce deve ser visto como uma base para o resto da vida, onde será construída e assegurada uma perfeita saúde bucal. A consulta para avaliação inicial do bebê deve acontecer por volta dos 6 meses de vida, época da erupção do primeiro dente, e no mais tardar aos 12 meses.

\subsection{1 - Papel da higiene bucal na prevenção de cárie em bebês}

SCHÖDER; GRANATH $(1983)^{73}$, pesquisaram os hábitos dietéticos e o padrão de higiene bucal de 143 crianças com idade média de 37 meses. Os autores utilizaram um questionário de freqüência alimentar para estabelecer o grau de consumo de alimentos cariogênicos e, através de exame clínico, definiram a prevalência de cárie e o padrão de higiene bucal baseado na condição gengival. Entre as crianças que apresentavam alto consumo de alimentos cariogênicos e um padrão ruim de higiene bucal, $89 \%$ possuíam lesões de cárie, enquanto que no grupo onde as crianças apresentavam um baixo consumo de alimentos cariogênicos e uma boa higiene bucal apenas $8 \%$ apresentavam lesões. As diversas combinações entre o padrão de higiene 
bucal e os hábitos dietéticos, demonstraram que a higiene bucal boa é mais efetiva para prevenir a cárie do que hábitos dietéticos adequados. Os autores concluíram que crianças com dentes limpos, independentes dos hábitos dietéticos, poderiam ser consideradas como sem risco à cárie.

PERSSON et al. $(1985)^{62}$ em estudo longitudinal com 312 crianças suíças aos 12 e aos 36 meses, constatou que as crianças que tinham seus dentes escovados ocasionalmente apresentavam lesões cariosas com maior freqüência (29\% tinham cárie) do que aquelas que os tinham escovados regularmente (13\% com cárie).

Em 1985 GORDON; REDDY ${ }^{27}$, a partir de uma amostra envolvendo 100 mães, constataram que $94 \%$ delas não haviam recebido conselhos de como cuidar dos dentes de seus filhos, $74 \%$ não os limpavam e, para a maioria delas a limpeza deveria começar entre 12 e 36 meses de idade, sendo que a escovação dental era o único método empregado. O ceod encontrado foi de 2,37 dentes. Os autores concluíram que as mães tinham um pequeno conhecimento sobre higiene oral e seus métodos.

Tento em vista que o contato bebê/pediatra acontece precocemente em relação ao contato bebê/odontopediatra, HERRMANN; ROBERTS (1987) ${ }^{33}$ escreveram um roteiro para os pediatras sobre os principais tópicos relacionados à saúde bucal em crianças, onde destacam o papel do médico em contribuir com o dentista na prevenção das doenças bucais. Sobre remoção de placa dentária, os autores orientam que ela deve ser realizada a partir da erupção do primeiro dente com o uso de uma fralda de tecido, de compressa de gaze ou escova dental pequena.

WINTER $(1988)^{99}$ revisando fatores predictivos do alto risco à cárie, dieta, higiene e medicamentos, relatou existirem muitos estudos que 
demostraram correlação positiva entre hábitos de higiene bucal em crianças jovens e a prevenção de cáries. Para o autor, as medidas preventivas adequadas devem ser instituídas precocemente.

RIPA (1988) ${ }^{68}$, em revisão sobre o assunto cárie de mamadeira em seus vários aspectos, inclusive sua prevenção, descreveu como quesito importante nos programas de educação para prevenção deste tipo de cárie a informação aos pais sobre a necessidade da limpeza dos dentes de seus filhos após cada alimentação.

ERONAT; EDEN ${ }^{19}$, em 1992, estudando alguns fatores que influem na cárie rampante ou de mamadeira em pré-escolares, compararam um grupo de 71 crianças que apresentavam cárie rampante com um grupo controle constituído de 224 crianças. Todas as crianças tinham entre 2 e 6 anos de idade. Foi verificado que no grupo controle a maioria das crianças tinha dieta balanceada, com uma quantidade normal de açúcar e que a higiene bucal foi mais regular do que no grupo com cárie rampante.

MEDEIROS $(1993)^{46}$ realizou um estudo objetivando elucidar os principais pontos a serem abordados na Odontologia preventiva para gestantes e bebês. Para o autor o aconselhamento pré-natal permite a instalação de um ambiente doméstico favorável ao desenvolvimento de hábitos corretos, que contribuirão para a saúde bucal da criança durante toda sua vida. O autor salientou a importância do conhecimento dos pais sobre a cariogenicidade do leite e que a higiene bucal do bebê deve começar tão logo os primeiros dentes irrompam na cavidade bucal, pois em muitos casos a falta dessas informações faz com que eles permitam o adormecer de seus filhos logo após, ou até mesmo durante o aleitamento. 
PAUNIO et al. $(1993)^{60}$ estudaram 1443 mães primíparas Finlandesas através de questionários aplicados durante a gestação, quando os filhos completaram 1 ano e meio e aos 3 anos de idade. Os resultados indicaram que os filhos das mães que relataram preferir iniciar os cuidados aos 3 anos ou mais tardiamente apresentavam uma higiene dental mais irregular, indicaram ainda, que as mães mais jovens possuíam mais freqüentemente filhos com escovação dental negligenciada e que a freqüência de higiene bucal esteve associada com o nível educacional e ocupacional das mães.

REISINE; LITT; TINANOFF $(1994)^{68}$ estudaram um modelo biopsicosocial de prever cáries em crianças pré-escolares. Os resultados mostraram que a contagem de $S$. mutans, o índice de cárie inicial e a freqüência de higiene bucal são fatores que predizem o risco de cárie significativamente.

ALALUUSUA; MALMIVIRTA (1994) ${ }^{1}$ estudaram crianças de 19 meses de idade buscando pesquisar alguns fatores associados ao aparecimento futuro de lesões de cárie aos 36 meses de idade. A presença de placa visível nas superfícies vestibulares dos incisivos superiores e o uso de mamadeira estiveram fortemente associados com o desenvolvimento de cárie nas crianças. Os resultados sugerem que a presença de placa visível na superfície vestibular dos incisivos superiores em crianças de pouca idade é um sinal de risco à cárie.

WENDT et al. (1994) ${ }^{98}$ realizaram estudo longitudinal em crianças de 1 e 3 anos de idade na Suécia, buscando descrever a relação entre hábitos de higiene bucal e a prevalência de cárie dentária. As crianças eram acompanhadas por um programa odontológico preventivo que previa orientações aos pais ao nascimento, 6 e 18 meses de idade da criança, sendo 
estimulados à iniciar a escovação dental com dentifrício fluoretado em seus filhos a partir de 1 ano de idade. As crianças foram examinadas com relação à cárie dentária, gengivite e presença de placa visível nas superfícies vestibulares dos incisivos superiores e outras informações foram coletadas a partir de entrevista realizada com os pais. Os resultados indicaram que quando o hábito de higiene bucal foi estabelecido com 1 ano de idade a probabilidade da criança estar livre de cárie aos 3 anos foi maior. As crianças com cárie aos 3 anos apresentavam maior prevalência de placa visível nos incisivos superiores e tiveram seus dentes escovados com menos freqüência aos 1 e 2 anos de idade. As crianças que tiveram seus dentes escovados com pasta fluoretada aos 2 anos de idade apresentaram uma menor prevalência de cárie aos 3 anos de idade. Os autores concluíram que o uso de flúor e os hábitos de higiene bucal são essenciais para a manutenção da saúde bucal durante os primeiros anos de vida.

KOROLUK et al. (1994) ${ }^{40}$ estudaram a distribuição de placa dentária e a prevalência de cárie em 138 crianças de 3 a 5 anos de idade no Canadá. Eles observaram que a presença de placa foi maior nos dentes posteriores do que nos anteriores e nas superfícies vestibulares quando comparadas às linguais. O índice total de placa associou-se com a prevalência de cárie dentária.

TSUBOUCHI et al. (1994) ${ }^{88}$ investigaram 683 crianças japonesas aos 18 meses. Os pais responderam à um questionário sobre os hábitos das crianças relacionados aos fatores de risco à cárie dentária. As crianças se submeteram a um exame dental, sendo que 13,7\% delas apresentavam lesões de cárie e o ceod foi de 0,27 dentes. Os resultados indicaram que a prevalência de cárie esteve associada ao desmame tardio (após 18 meses de idade), ao padrão de higienização bucal deficiente e à ingestão de lanches de forma irregular. 
Através de exame clínico e radiográfico, STECKSÉN-BLICKS; HOLM $(1995)^{79}$ determinaram a prevalência de cárie em um grupo de 249 crianças com 4 anos de idade na Suécia. Quando as crianças tinham 1 ou 2 anos de idade $80 \%$ dos pais receberam orientações sobre saúde bucal. Os pais participaram de uma entrevista sobre hábitos de higiene bucal, uso de dentifrício fluoretado e pastilhas com flúor e responderam a um questionário de freqüência de consumo de nove diferentes alimentos doces. O consumo de doce foi ponderado de acordo com sua freqüência semanal e um valor foi atribuído. Os resultados indicaram que as crianças com alto consumo de alimentos doces apresentaram uma prevalência de cárie maior, quando comparadas com crianças com menor consumo destes produtos. A higiene bucal regular realizada com a ajuda dos pais teve um impacto positivo sobre a prevalência de cárie, sendo o índice ceod no grupo que não realizava higiene bucal regularmente ou não contava com a ajuda dos pais foi de 3,7 dentes, enquanto que no grupo que recebia auxílio dos pais e escovavam os dentes com freqüência de 1 ou 2 vezes ao dia a experiência de cárie foi de 1,6 e 1,3 dentes respectivamente. $O$ efeito positivo da higiene bucal ocorreu com maior impacto no grupo onde a freqüência de consumo de doces era alta. No grupo onde o consumo de alimentos doces foi considerado alto e a higiene bucal irregular, todas as crianças apresentavam lesões de cárie e o ceod foi 5,7 dentes. Já no grupo com higiene regular e consumo de açúcar menor, aproximadamente $60 \%$ das crianças eram livres de cárie e o ceod foi de 1,4 dentes. Os autores concluíram que a higiene bucal irregular potencializa o impacto negativo do consumo freqüente de alimentos doces e que a freqüência de higiene bucal é um bom indicador de outros hábitos relacionados à saúde 
bucal . A importância de dar orientações aos pais de como limpar o dente de seus filhos desde cedo também foi salientada.

ROETERS et al. (1995) ${ }^{69}$ estudaram longitudinalmente os determinantes da cárie dentária em crianças de 2 a 5 anos de idade na Holanda. A amostra constou de193 crianças com a idade entre 1,9 a 2,8 anos (média de 2,3 anos) foram avaliadas durante 3 anos através de exame bucal da criança, entrevistas com os pais e ao final do estudo radiografias interproximais. As visitas eram a cada 6 meses e os pais eram aconselhados quanto a dieta, uso de flúor e higiene bucal. Os hábitos alimentares, de higiene bucal e do uso de flúor eram inquiridos a cada visita e o grau de instrução da mãe foi usado como parâmetro do nível social. Os resultados apontaram uma correlação negativa entre o nível de instrução da mãe e ceod. Quanto à ingestão de açúcar a correlação com o ceod foi baixa. Não foi encontrada correlação entre uso de flúor e freqüência de escovação com o ceod. Os autores explicam que a alta correlação do nível de instrução da mãe x ceod possivelmente ocorre porque indivíduos com mais alto grau de escolaridade apresentam um comportamento mais favorável a saúde bucal, eles comem menos doce, escovam seus dentes mais freqüentemente e visitam o dentista mais regularmente. Por outro lado a baixa correlação entre hábitos dietéticos e freqüência de higiene $\mathrm{x}$ ceod pode ser devido a baixa confiabilidade dos dados obtidos dos pais e também pelo fato da prevalência de cárie na população estudada ser baixa.

GRINDEFJORD et al. $(1995)^{30}$ estudaram a eficácia de fatores como hábitos alimentares, contagem de mutans, higiene bucal, avaliados em crianças de 1 ano de idade, em prever o risco do desenvolvimento de cáries. Quando a criança tinha 1 ano de idade foi realizado um exame clínico e microbiológico (para detectar a presença de $S$. mutans), além do 
preenchimento de um questionário pelo responsável sobre a saúde geral da criança, hábitos alimentares, de higiene e exposição ao flúor. Aos 3,5 anos a criança era submetida à outro exame clínico. Contrapondo os dados iniciais fornecidos pelos pais e a atividade de cárie das crianças aos 3,5 anos, os autores concluíram que fatores sociodemográficos, hábitos alimentares, ocorrência de $S$. mutans e higiene bucal devem ser avaliados quando se quer prever o risco à cárie de um bebê.

THOMAS (1997) ${ }^{82}$ em um protocolo racional para o cuidado da saúde bucal infantil, reforça a importância de os pais receberem instruções apropriadas sobre higiene bucal e remoção da placa dentária, pois a presença de placa visível na superfície vestibular dos incisivos superiores é um forte fator para se estabelecer o risco da criança em desenvolver a doença cárie.

ISMAIL $(1998)^{36}$ em revista da literatura, face às evidências de que o acúmulo de placa dentária na superfície vestibular dos incisivos superiores em bebês é um bom predictor do desenvolvimento de cárie, concluiu que o estabelecimento do hábito de higiene bucal precocemente deve ser amplamente estimulado. Ainda, segundo o mesmo autor, a condição de alto risco à cárie pode ser estabelecido através da experiência prévia de cárie, pela identificação de sinais precoces de cárie dental (mancha branca), pela evidência de pobre higiene oral e por hábitos dietéticos inapropriados.

Discutindo sobre aspectos da cárie precoce da infância WEINSTEIN $(1998)^{97}$ acredita que as clínicas odontológicas públicas também devem se dedicar a prevenção e controle desta através de repetidas abordagens da mãe e da criança durante as visitas médicas pré e pós-natais. Segundo o autor, os pais devem ser estimulados a praticar medidas que reduzam o risco à cárie: substituição da mamadeira pelo copo, não permitir que a criança durma com a 
mamadeira na boca (exceto quando o conteúdo for água), reduzir o número de lanches e bebidas doces, realizar limpeza bucal diária (mesmo que o bebê proteste) e visitas regulares ao dentista a fim de identificar sinais precoces de cárie.

No Brasil, MATTOS-GRANER et al. $(1998)^{44}$ estudaram a associação entre cárie dentária e variáveis clínicas, microbiológicas e dietéticas em crianças de 1 a 2,5 anos de idade. A amostra foi composta de 142 crianças freqüentadoras de creches públicas que foram submetidas a exame de cárie (ceos), observação da presença de placa dentária visível na superfície vestibular dos incisivos superiores e exame de contagem de $S$. mutans na saliva. As mães dessas crianças foram entrevistadas sobre os hábitos de aleitamento, conteúdo da mamadeira e início da introdução de alimentos salgados. Os resultados indicaram que as variáveis mais fortemente relacionadas com a cárie em crianças dessa idade foram os níveis de $S$. mutans e o acúmulo de placa nos incisivos superiores.

Para GIBSON; WILLIAMS (1999) ${ }^{24}$ em um estudo sobre cárie em crianças pré-escolares britânicas, onde foi estudada sua associação com classe social, hábito de escovação dental e consumo de açúcares, a escovação dentária diária duas vezes ao dia pode ter maior impacto contra cárie nestas crianças jovens, do que a restrição de alimentos açucarados.

UDIN ${ }^{89}$ em 1999, revisando novas maneiras de prevenir cárie dentária em crianças, relatou que o tratamento restaurador da cárie precoce da infância é muito dispendioso. Para o autor, visando a prevenção da doença cárie, a primeira intervenção a ser feita é controlar o substrato das bactéria e instituir medidas de higiene bucal agressivas. A limpeza bucal deve começar tão logo o 
primeiro dente apareça na cavidade bucal, e isto deve ser bastante enfatizado com os pais.

Em estudo sobre prevalência de cárie em aborígenes australianos urbanos de 1 a 3,5 anos de idade, SEOW et al. $(1999)^{74}$ constataram que os altos índices de cárie encontrados estavam associados ao alto índice de placa, à alta contagem de $S$. mutans e ao consumo de leite durante o sono. Além disso, moderados a altos índices de placa em mais de metade das crianças, indicativo de uma higiene ineficaz ou inexistente, foi um significante fator de risco à cárie na população estudada.

\subsection{2 - Métodos para higiene bucal em bebês}

Em 1929, PEREIRA ${ }^{61}$ apud GARBOZA; WALTER $(1997)^{22}$ ressaltava que os dentes dos bebês, em função da dificuldade de sua escovação, necessitavam de limpeza com gaze, envolvida no dedo, e embebida em solução de bicarbonato de sódio.

GUEDES-PINTO; CRUZ; PARREIRA $(1972)^{31}$, escreveram sobre os aspectos gerais e as técnicas de escovação dental aplicadas à crianças, com o intuito de mostrar aos odontopediatras e clínicos em geral como melhor orientar seus clientes. Segundo eles, o início da escovação dental deve ocorrer o mais cedo possível, e sempre realizada pelos pais ou responsáveis.

GOEPFERD $(1986)^{26}$ em um protocolo sobre atenção odontológica precoce, destinou um tópico para falar sobre a limpeza bucal em bebês. Segundo o autor esta limpeza deve ficar a cargo de um adulto (pais, responsável por seu cuidado), pois as crianças são incapazes de realizar boa higiene bucal até a idade de 8 anos. A higiene deve ser feita com gaze ou fralda quando da erupção dos primeiros dentes e trocada por uma escova de 
dentes quando eles se sintam confortáveis com a mudança. Este procedimento deve ser realizado pelo menos uma vez ao dia, entretanto ela é recomendada após toda refeição.

MEDEIROS $(1993)^{46}$ recomenda que a higiene bucal deve ser realizada pelo menos uma vez ao dia com o uso de uma fralda ou gaze enrolada no dedo indicador da pessoa responsável pela limpeza, preferencialmente após a última mamada. Na medida em que o bebê se habitua à rotina diária de higienização, também podem ser utilizadas escovas dentais pequenas e com cerdas macias ou dedeiras com cerdas de látex.

DEAN; HUGHES $(1995)^{16}$, relataram instruções específicas para a higiene bucal praticada no lar relacionada à idade. Segundo os autores, o processo de limpeza bucal para crianças de até 1 ano de idade deve ser realizado com uma compressa de gaze, chumaço de algodão ou ponta de fralda úmidos, que são envolvidos nos dedos dos pais e passados em torno dos dentes e dos tecidos gengivais. A partir de 1 ano de idade, deve ser iniciado o uso da escova dentária, mas os pais continuam responsáveis pela higiene.

Segundo WALTER; FERELLE; ISSÁO (1996) ${ }^{94}$, a limpeza bucal começa com a erupção dos primeiros dentes, principalmente à noite após a última mamada. Essa limpeza deve ser realizada com uma fralda embebida em uma solução de água oxigenada 10 volumes e água filtrada (1:3) e deve seguir até 18 meses e/ou quando da completa erupção dos primeiros molares decíduos. A partir daí, deve-se iniciar a escovação, principalmente para limpeza das superfícies oclusais desses dentes.

Para OPPENHEIM $(1996)^{59}$ é uma responsabilidade dos dentistas assistir pacientes de tenra idade e, educar seus pais sobre a saúde bucal de 
seus filhos. Os fatores a serem abordados são: cárie, dieta, limpeza bucal, uso do flúor e hábitos não nutritivos. Quanto à higiene, ele relata que os pais são muito conscientes sobre a limpeza geral do corpo, mas é surpreendente quão pouco sabem sobre a necessidade de fazer o mesmo na cavidade bucal. Os pais devem ser orientados de que inicialmente uma gaze é o suficiente para realização desta limpeza e posteriormente uma escova pequena o é.

KRAMER; FELDENS; ROMANO $(1997)^{41}$ enfatizam a importância do controle de placa em bebês de 12-24 meses, pois nessa fase, surgem na cavidade bucal as superfícies oclusais dos molares decíduos. A técnica a ser utilizada é aquela que melhor se adapta a cada caso, mas sobretudo há a necessidade que um adulto assuma a responsabilidade da higienização bucal em pacientes dessa idade.

De acordo com SERINO; GOLD $(1997)^{75}$, a higiene bucal deve ser realizada inicialmente com uma gaze ou fralda enrolada no dedo cuidadosamente esfregada sobre os rodetes gengivais pelo menos uma vez ao dia, para acostumar a criança ao processo. Depois que os primeiros dentes irromperem ela deve continuar a ser realizada da mesma forma e, posteriormente, assim que a criança cresce, a gaze ou fralda pode ser substituída por uma escova de dente pequena e macia.

Em 1997, MELO; WALTER ${ }^{47}$, estudaram o comportamento de bebês de 0 a 30 meses de idade em relação ao ato da higiene bucal, através de questionário respondido pelas mães de bebês pacientes da Bebê-Clínica da UEL e prontuários da própria clínica. Os resultados mostraram haver mudanças no comportamento infantil, a primeira acontece quando se inicia a erupção dos dentes e ela se torna arredia à higienização e outra quando se introduz a escova dental com dentifrício, e sua conduta se altera positivamente. Nas 
crianças sem dentes, prevaleceu a conduta positiva (54\%), com o aparecimento de dentes $55 \%$ das crianças apresentaram conduta negativa ou indefinida perante a higienização com gaze embebida em $\mathrm{H}_{2} \mathrm{O}_{2}$ e com a introdução da escova dental com dentifrício a maioria $(59,9 \%)$ apresentou melhora no comportamento, o que os levou a concluir que as crianças preferem o uso da escova e creme dental à limpeza com gaze embebida em $\mathrm{H}_{2} \mathrm{O}_{2}$. Também foi abordado nesse questionário qual escova dental era utilizada pelas mães e, 56\% delas responderam que utilizavam qualquer escova, 32,6\% que usavam escova própria para bebês e 11,4\% escovas fornecidas pelo dentista.

Avaliando a prática da higiene bucal em crianças de 1 a 7 anos de idade em creches e escolas públicas e privadas, VILLENA et al. $(1997)^{90}$ encontraram que a escova dental ainda é o método mais utilizado. Mas métodos alternativos (fralda, gaze e cotonete) também foram reportados por $38 \%$ e $3 \%$ para 0 primeiros e segundo ano de vida respectivamente em instituições privadas e 47,8\% e 13,9\% em instituições públicas.

Em 1997, VILLENA; BORGES; RODRIGUES ${ }^{92,93}$ testaram a efetividade na remoção da placa dentária promovida por diferentes métodos indicados para higiene bucal em bebês: escova dental (G.U.M - 100, ButlerÒ), dedeira de silicone (FarlinÒ) e ponta de fralda. A amostra constou de 30 crianças de 11 a 27 meses, freqüentadoras de uma creche de São Paulo, divididas em 3 grupos de 10 crianças. As crianças tiveram seus dentes higienizados por duas funcionárias da creche, sem treinamento prévio e em cada grupo foi usado um tipo de dispositivo diferente para a limpeza. A amostra constou de 30 crianças freqüentadoras de uma creche de São Paulo, divididas em 3 grupos de 10 crianças. A avaliação clínica foi realizada por um único examinador, com a criança deitada joelho-a-joelho , sem o uso de evidenciador de placa, sob luz 
natural e prévia secagem dos dentes com pêra de ar. Os dentes considerados na avaliação foram os anteriores superiores e inferiores, utilizando-se o índice PHP. A título de comparação entre os métodos foram utilizados os coeficientes de redução (índice final subtraído do índice inicial) dos mesmos. Os resultados mostraram uma redução média de placa de $29,6 \%, 47,7 \%$ e $62,9 \%$, quando a dedeira, a fralda de tecido e a escova foram respectivamente utilizadas, havendo diferença estatisticamente significante entre os grupos da dedeira e escova. Os autores concluíram que a escova foi mais eficiente na remoção de placa bacteriana do que os métodos alternativos.

Em publicação que revisa e discute as orientações sobre saúde bucal em bebês, WANDERA $(1998)^{98}$ relata que os procedimentos de higiene bucal devem começar com a irrupção do primeiro dente, preferencialmente com uma escova macia e de cabeça pequena. Ela salienta a importância da limpeza após a última mamada, antes do bebê ir para a cama.

MARTINS; TESSLER; CORRÊA $(1998)^{43}$ recomendam o início da higienização bucal, tão logo os primeiros dentes irrompam. Essa higiene deve ser feita com escova dental pelos responsáveis. A escova a ser utilizada para crianças com até 3 anos de idade deve apresentar cabeça pequena, cerdas extramacias com extremidades arredondadas, ser estreita e oferecer boa empunhadura.

Ressaltando a importância de educar pais/responsáveis quanto à introdução mais precoce possível do hábito de higiene bucal, TOLLARA; SALIM; CORRÊA $(1998)^{86}$ relatam os diversos métodos de higiene bucal e posições de escovação para a primeira infância. Os métodos de higiene bucal citados foram: dedeiras especiais, compressa de gaze ou algodão, fralda limpa embebidas em água ou solução de água oxigenada diluída em água fervida 
(1:4) para as mucosas e língua, e tão logo os primeiros dentes irrompam se torna necessário o uso da escova dental infantil, de cerdas macias. Em relação a posição, os autores sugerem: criança no colo do responsável, joelho/joelho, criança no colo do responsável entre suas pernas e criança sem contenção (deitada, sentada ou em pé).

SANTOS; GUEDES-PINTO (1998) ${ }^{71}$, relataram que os procedimentos de remoção de placa geralmente devem começar quando da erupção dos primeiros dentes decíduos. Esta limpeza deve ser feita pelas pais com o uso de compressa de gaze ou a ponta de uma fralda, úmida, envolvidas no dedo dos pais. Por volta dos 2 anos, pode ser utilizada a escova dentária.

Em 1999, BORGES et al. ${ }^{12}$ compararam a efetividade de remoção de placa de uma escova convencional (Oral B 20) e de uma escova alternativa desenvolvida especialmente para bebês (Científica Baby). A amostra foi composta por 24 crianças com idade entre 10 e 33 meses de uma creche de São Paulo. A higiene foi realizada por uma funcionária da creche, e as 2 escovas foram testadas em todas as crianças. A avaliação clínica foi conduzida por um único examinador, através da realização do índice de placa (PHP) antes e depois da escovação com auxílio de solução evidenciadora fosforescente sob fonte de luz polimerizadora e os dentes avaliados foram os anteriores superiores e inferiores. A redução de placa da escova convencional e da experimental foi de $45,94 \%$ e $46,13 \%$ respectivamente. A diferença entre as duas não foi estatisticamente significante.

EDUARDO; LONG; CHELOTTI (1999) ${ }^{18}$ avaliaram as posições adotadas pelos adultos durante a escovação em crianças durante a primeira infância. $O$ estudo foi realizado com 30 crianças ente 3 e 4 anos e 3 cirurgiãs-dentistas. A higienização foi feita com escova dental Oral B 25 utilizando-se a técnica de 
Fones durante 2 minutos. As posições assumidas foram as seguintes: 1 pessoa que vai executar a escovação fica em pé por trás da criança e esta apoia sua cabeça no corpo da profissional (conhecida como posição de Starkey); 2 - pessoa que executa a escovação fica em frente à criança, esta encosta na parede apoiando sua cabeça; 3 - a pessoa que executa a escovação senta-se em uma cadeira e a criança fica deitada com a cabeça apoiada em seu colo. Para a avaliação das posições, após a escovação a criança mastigava pastilha evidenciadora de placa e eram anotadas as superfícies que ainda apresentavam placa. Os resultados permitiram aos autores concluir que a posição 2 foi a menos satisfatória apresentando um percentual de placa de 0,54 e as posições 1 e 3 mostraram eficácia equivalente, sendo que a posição 3 apresentou um percentual de 0,31.

Ao avaliarem a eficácia de métodos de higiene bucal em bebês, MOURA et al. (2000) ${ }^{52}$ também observaram a reação dos bebês frente às técnicas utilizadas e conscientizaram os pais da necessidade de iniciarem precocemente a higiene bucal em seus filhos. A amostra constou de 43 bebês cadastrados no "Programa Preventivo Para Gestantes e Bebês" da Universidade Federal do Piauí, que apresentavam os 8 incisivos presentes na cavidade bucal. Foram testadas 3 técnicas: 1 - Fralda $(10 \times 10 \mathrm{~cm})$ envolvida no dedo indicador e embebida em água filtrada. 2 - Escova Infantil (Kollynos) com creme dental infantil (Tandy). 3 - Pedaço de fralda $(10 \times 10 \mathrm{~cm})$ envolvido no dedo indicador embebido em solução de água oxigenada 10 volumes e água filtrada (1:3). Durante a realização do experimento o bebê ficava na posição joelho/joelho e a seguinte rotina foi adotada: motivação dos pais, evidenciação da placa com a Solução de Verde de Malaquita 10\% e remoção da placa das superfícies dentárias de acordo com a técnica proposta (sempre a mesma 
técnica em todas as sessões) e aplicação de flúor gel por 1 minuto. Essa seqüência foi repetida em 3 sessões a cada 3 meses. Em toda sessão o comportamento dos bebês era avaliado em: bom, regular ou colaborador. Os resultados mostraram que das 3 técnicas avaliadas, a da escova foi a mais eficiente na remoção da placa, seguida pela fralda com água filtrada e por último pela fralda com solução de água oxigenada. Quanto a aceitação das técnicas pelos bebês, esta foi maior quando utilizou-se a técnica 1, mas para todas as técnicas houve uma melhora geral de comportamento ao longo das sessões. 
3. PROPOSIÇÃO 


\section{PROPOSIÇÃO}

Este estudo teve como objetivo avaliar clinicamente, em bebês de 12 a 36 meses:

3.1 - o índice de placa dentária antes e após a higiene bucal realizada por mães e por um Odontopediatra, utilizando cinco diferentes dispositivos utilizados para higiene bucal em bebês:

- Fralda de tecido,

- Compressa de gaze,

- Escova dental "Científica Baby",

- Escova dental para uso no dedo "Infa-Dent",

- Escova dental "Dental Prev Baby",

3.2 - a eficácia desses dispositivos em remover placa dentária em duas condições:

- em pacientes apenas com dentes anteriores,

- em pacientes com a presença de pelo menos 2 dentes posteriores, além dos anteriores.

3.3 - o comportamento dos pacientes frente à utilização dos diferentes métodos;

3.4 - a preferência das mães pelos diferentes métodos. 
4. MATERIAL E MÉTODOS 


\section{MATERIAL E MÉTODOS}

\section{1 - Seleção da amostra}

Para constituir a amostra foram selecionados bebês com idade entre 12 e 36 meses, que possuíssem no mínimo 4 dentes decíduos na boca, com pelo menos 1/2 da coroa exposta e livres de cárie. As idades consideradas foram aquelas que as crianças apresentavam ao início da fase experimental da pesquisa. Para triagem dos pacientes foram utilizados os prontuários da Clínica de Bebês da disciplina de Odontopediatria da Faculdade de Odontologia de Bauru. Inicialmente foram chamadas 88 crianças, no dia marcado compareceram apenas 49 sendo que, permaneceram até o final do estudo 36 participantes. Com o intuito de aumentar a amostra foram selecionados crianças freqüentadoras da creche comunitária "Monteiro Lobato". Essa seleção foi feita através de exame clínico bucal na própria creche após autorização dos pais ou responsável legal pela criança.

O número total final da amostra (Tabela 1) foi de 63 bebês de ambos os sexos, sendo 36 pacientes da Clínica de Bebês da disciplina de Odontopediatria da Faculdade de Odontologia de Bauru e 27 crianças freqüentadoras da creche comunitária "Monteiro Lobato".

As crianças foram separadas em grupos de acordo com sua procedência em:

Grupo A - crianças pacientes da Clínica de Bebês

Grupo B - crianças da creche Monteiro Lobato 
Depois foram divididas novamente, de acordo com a presença ou não de dentes posteriores, em dois sub-grupos:

Sub-grupo Anteriores - subgrupo de crianças com presença apenas de dentes anteriores irrompidos, não importando o número

Sub-grupo Posteriores - subgrupo de crianças com a presença de pelo menos 2 dentes posteriores irrompidos, além dos anteriores.

A subdivisão foi feita devido à variação quanto a indicação dos métodos de higiene bucal de um grupo para outro.

Tabela 1 - Distribuição das crianças incluídas na pesquisa, por grupo, subgrupo.

\begin{tabular}{lcccc}
\hline & \multicolumn{2}{c}{ GRUPO A } & \multicolumn{2}{c}{ GRUPO B } \\
\cline { 2 - 5 } IDADE & $12-24$ & $25-36$ & $12-24$ & $25-36$ \\
SUB-GRUPO & 13 & - & 7 & 3 \\
ANTERIORES & 7 & 16 & 3 & 14 \\
POSTERIORES & 20 & 16 & 10 & 17 \\
TOTAL & & &
\end{tabular}

Cumprindo o regimento do Comitê de Ética em Pesquisa da Faculdade de Odontologia de Bauru - USP (de acordo com a Resolução n 196/96 do Conselho Nacional do Ministério da Saúde) que aprovou a realização deste estudo (anexo 1), os pacientes só passaram a fazer parte da amostra mediante assinatura de seus pais ou responsável legal no termo de autorização (anexo 2), após explicação minuciosa e detalhada sobre os objetivos do estudo e os procedimentos a serem realizados durante o mesmo, informações essas presentes na carta de informação ao paciente (anexo 3) entregues à eles no mesmo momento. 


\section{2 - Material utilizado}

Foram testados cinco diferentes dispositivos para a realização da higienização dentária em bebês disponíveis no mercado brasileiro, que se encontram listados na tabela abaixo (Tabela 2).

Tabela 2 - Dispositivos para higiene bucal de bebês testados , nome comercial, empresa/ fabricante e custo unitário (reais)*.

\begin{tabular}{|c|c|c|c|c|}
\hline Dispositivo & Nome Comercial & Fabricante & Procedência & $\begin{array}{c}\text { Preço } \\
\text { /un. }\end{array}$ \\
\hline Fralda de tecido & $\begin{array}{l}\text { Fralda Cremer } \\
\text { Especial - } \\
\text { Tecido Duplo }\end{array}$ & Cremer S. A. & Brasil & 1,07 \\
\hline $\begin{array}{l}\text { Compressa de } \\
\text { Gaze Hidrófila }\end{array}$ & $\begin{array}{l}\text { Compressas de } \\
\text { Gaze Íris }\end{array}$ & Cremer S.A. & Brasil & 0,015 \\
\hline Escova Dental & Científica Baby & $\begin{array}{l}\text { Dental Line Ind. e } \\
\text { Com. de Prod. } \\
\text { Odontológicos }\end{array}$ & Brasil & 3,00 \\
\hline $\begin{array}{l}\text { Escova Dental } \\
\text { para uso no dedo }\end{array}$ & Infa - Dent & $\begin{array}{l}\text { Laclede } \\
\text { Professional } \\
\text { Products }\end{array}$ & E. U. A. & 5,00 \\
\hline Escova Dental & $\begin{array}{l}\text { Dental Prev } \\
\text { Baby }\end{array}$ & $\begin{array}{l}\text { Ind. Com. e } \\
\text { Representações } \\
\text { Poli Products Ltda }\end{array}$ & Brasil & 2,19 \\
\hline
\end{tabular}

A limpeza com a fralda (Fig. 4) foi realizada com um quadrado de $15 \mathrm{~cm} \times 15 \mathrm{~cm}$ do tecido, enrolado no dedo indicador da pessoa que realizaria a higiene, método este amplamente indicado na literatura ${ }^{16,26,46,71,75,86,94}$, para a

\footnotetext{
* Valores referentes à cotação feita em 01/06/2000.
} 
higiene bucal em bebês a partir da irrupção do primeiro dente até o início da erupção dos dentes posteriores .

A compressa de gaze também foi utilizada da mesma maneira que a fralda de tecido, como mostra a Fig. 5. Na literatura este método também tem a mesma indicação da fralda ${ }^{16,26,46,61,71,75,86}$.

A escova dental Científica Baby (Fig. 6), segundo a bula que a acompanha, é a única a ser desenvolvida especificamente para a delicada boca dos bebês e foi criada por Bignelli e colaboradores ${ }^{6}$, com o intuito de facilitar a higienização bucal em bebês em substituição à gaze ou ponta de fralda, consideradas por ele como precárias. Confeccionadas pelo sistema monobloco ela possui um limitador de segurança que delimita a parte ativa da escova, a qual penetrará na cavidade bucal. Ela é recomendada pelo fabricante a partir dos 4 meses até os 3 anos. Esta escova é vendida somente em um kit contendo 2 unidades, uma com cabo maior, indicada para a mãe realizar a escovação no bebê e outra com cabo de tamanho reduzido, mas com as mesmas características da outra, feita para o próprio bebê imitar a escovação realizada pela mãe.

A escova dental para uso no dedo e massageador de gengivas Infa-Dent (Fig. 7), mais conhecida pela população leiga como dedeira de borracha, segundo o próprio fabricante é indicada para crianças de 3 meses a 2 anos, sendo um recurso para limpar dentes pequenos e massagear as gengivas, de uma forma mais fácil para mãe e para o bebê.

A escova Dental Prev Baby (Fig. 8) possui cerdas de nylon extra macias arredondadas e polidas que segundo o fabricante não ferem as gengivas do bebê. Sua cabeça é pequena e arredondada e o cabo é mais comprido e 
anatômico, permitindo uma perfeita empunhadura. O fabricante recomenda seu uso a partir do aparecimento dos primeiros dentes.

Vários autores ${ }^{1,44,49,92,93}$ relatam como parâmetro de presença de placa sobre a superfície dentária o que se denomina de "placa clinicamente visível", contudo, no estudo piloto realizado previamente a este experimento, foi encontrada dificuldade em mostrar a placa para as mães e até mesmo o profissional por vezes, não conseguia visualizá-la mesmo estando presente, fato este constatado quando foi utilizado um evidenciador de placa dentária.

Como um dos propósitos deste trabalho foi avaliar a eficácia dos dispositivos na remoção da placa dentária, optou-se pelo uso de uma substância corante para evidenciá-la, no caso, o Verde de Malaquita a 0,6\% (de acordo com orientação da disciplina de Periodontia da FOB-USP). Uma vez que na composição desta solução encontra-se o álcool etílico, para que este não viesse a causar desconforto ou lesões à mucosa bucal do bebê, este foi substituído por álcool de cereais, substância menos agressiva usada em fórmulas homeopáticas de boa aceitação pelas crianças.

\section{3 - Fase experimental}

Para que as condições de higiene bucal estivessem padronizadas, cada bebê recebeu uma profilaxia profissional com taça de borracha e escova de Robinson (quando havia presença de dentes posteriores) e pasta dental sem flúor First Teeth', 7 dias do início do experimento. Antes da realização desta limpeza, realizou-se evidenciação da placa e tomada do índice de placa inicial. As mães ou responsáveis foram instruídas a não higienizar os dentes desses

\footnotetext{
${ }^{1}$ Laclede Professional Products, Inc
} 
bebês durante as 48 horas antecedentes à próxima sessão. Durante a realização dos procedimentos as crianças, de ambos os grupos, foram acomodadas em uma maca odontopediátrica Easy Baby ${ }^{2}$ (Fig. 9). O estudo foi realizado de uma forma cruzada ou seja, todos os indivíduos da amostra tiveram seus dentes higienizados com todos os dispositivos.

\subsection{1 - Primeira Sessão}

Os dentes eram corados com um cotonete embebido na solução de Verde de Malaquita a 0,6\% (Fig.10) e o índice de placa inicial era registrado.

Neste estudo o índice de higiene bucal escolhido foi o proposto por QUIGLEY; HEIN ${ }^{5}$ em 1962, exatamente porque este foi proposto para avaliar a eficiência de diferentes tipos de escovas dentais. Tal escolha alicerça-se ainda pela grande utilização do mesmo em trabalhos anteriores, além da fácil aplicação, o que se torna imprescindível quando se trabalha com bebês.

De acordo com este índice todos os dentes presentes na cavidade bucal devem ser avaliados, mas como nesse caso os pacientes se encontravam em fase de irrupção dentária, foram avaliados apenas os dentes com mais de $1 / 2$ da coroa na cavidade bucal, durante o $1^{\circ}$ exame.

Em cada dente foram avaliadas as faces vestibular e lingual, as quais foram divididas em 3 partes iguais, e de acordo com a quantidade de placa, eram dados os seguintes escores como mostra a Fig. 11:

\footnotetext{
${ }^{2}$ Easy Baby Comércio Varejista de Móveis Médicos - Odontológicos
} 


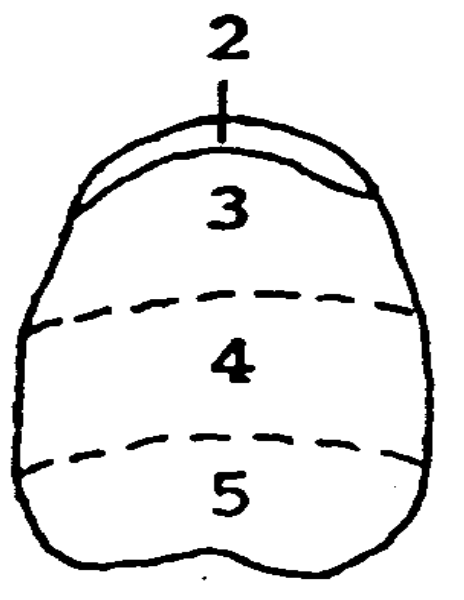

0. Sem placa

1. Pequenos pontos isolados de placa na margem gengival

2. Linha definida de placa na margem gengival

3. Placa em até $1 / 3$ da superfície

4. Placa em até $2 / 3$ da superfície

5. Placa em mais de $2 / 3$ da superfície

FIGURA 11 - Escores para avaliar a quantidade de placa presente, segundo o Índice de Quigley; Hein ${ }^{65}$.

No caso das crianças do subgrupo 2, que já apresentavam dentes posteriores na cavidade bucal, foram avaliadas também as superfícies oclusais e para tal foi utilizado um índice preconizado por MESTRINHO; CARVALHO; FIGUEIREDO ${ }^{48}$ que utiliza os seguintes escores:

0. Sem placa

1. Placa fina restrita ao sistema sulco-fossa

2. Placa espessa restrita ao sistema sulco-fossa

3. Placa espessa cobrindo a superfície oclusal parcial ou totalmente.

Os exames foram realizados por um único profissional, Odontopediatra e os dados foram anotados em fichas apropriadas (anexo 4). O índice total da boca foi calculado pela soma de todos os escores dividido pelo número de superfícies examinadas em cada paciente.

No grupo $A$, a realização da higiene dentária da criança foi feita pela própria mãe ou pelo responsável pelos cuidados da criança, sendo que em todas as sessões subsequentes a mesma pessoa deveria estar presente para a realização da mesma. No grupo $B$, a limpeza dentária foi realizada por um 
Odontopediatra, sendo que as mães não estavam presentes nas sessões e as crianças eram acompanhadas por uma das pessoas responsáveis por seu cuidado na creche. Tanto as mães, quanto o Odontopediatra se encontravam na mesma posição durante a realização dos procedimentos de higienização em todas as sessões: posicionados atrás da cabeça da criança (Fig. 12).

As mães ou responsáveis que realizavam a higiene foram orientados a proceder de maneira habitual ou seja, repetir o que faziam em casa, sendo que todas elas já haviam recebido instruções à respeito desse assunto anteriormente, quando das visitas mensais à Clínica de Bebês. Nenhuma técnica em especial foi recomendada. Quanto à duração da limpeza, não foi estipulado tempo, as mães foram instruídas a continuarem limpando até que considerassem os dentes totalmente limpos e o tempo de duração da higienização foi cronometrado.

Quanto a higienização realizada pelo Odontopediatra, esta teve seu tempo estipulado em 60 segundos em pacientes com apenas 4 ou 6 incisivos, 90 segundos naqueles com 8 incisivos. Para os pacientes do subgrupo 20 tempo foi de 180 segundos para os que já apresentavam os $41^{\text {os }}$ molares e 240 segundos para àqueles que possuíam dentição decídua completa. A técnica utilizada para higienização foi a dos movimentos horizontais, seguindo sempre uma mesma seqüência (Fig. 13), começando pela face vestibular dos dentes do quadrante superior esquerdo seguindo até o quadrante inferior esquerdo, passando posteriormente para as faces linguais do arco inferior esquerdo e terminando no arco superior esquerdo. Finalmente eram limpas as faces oclusais. 
Após a conclusão da higienização tanto do grupo A quanto do grupo B, os dentes eram corados novamente e o índice de placa final era registrado.

Durante a realização da higienização o comportamento da criança foi avaliado, conforme descrito anteriormente. Durante os procedimentos realizados em cada sessão a criança que se mostrasse não colaboradora era contida afim de permitir a realização dos mesmos. Ao fim de cada sessão foi realizada nova profilaxia profissional, da mesma maneira daquela realizada na primeira sessão. Novamente as mães eram informadas da necessidade de não realizar a limpeza dos dentes dos bebês por 48 horas antes da próxima sessão, sessão esta que era marcada semanalmente. Desse modo cada período experimental compreendeu 2 dias de acúmulo de placa, 1 dia para realização do experimento seguido de 4 dias de descanso, nos quais as mães retomavam a rotina de higiene habitual.

O método utilizado para limpeza dentária variava a cada sessão e era escolhido de maneira aleatória, sendo que em cada sessão cada dispositivo era utilizado em aproximadamente $20 \%$ da amostra. Todos os dispositivos foram usados sem creme dental, apenas embebidos em água potável.

\subsection{2 - Demais Sessões $\left(2^{a}-5^{a}\right)$}

Foi seguida a mesma rotina da segunda sessão. Na última sessão inquiriu-se às mães qual era o método de sua preferência para realizar a higiene bucal em seus filhos. 


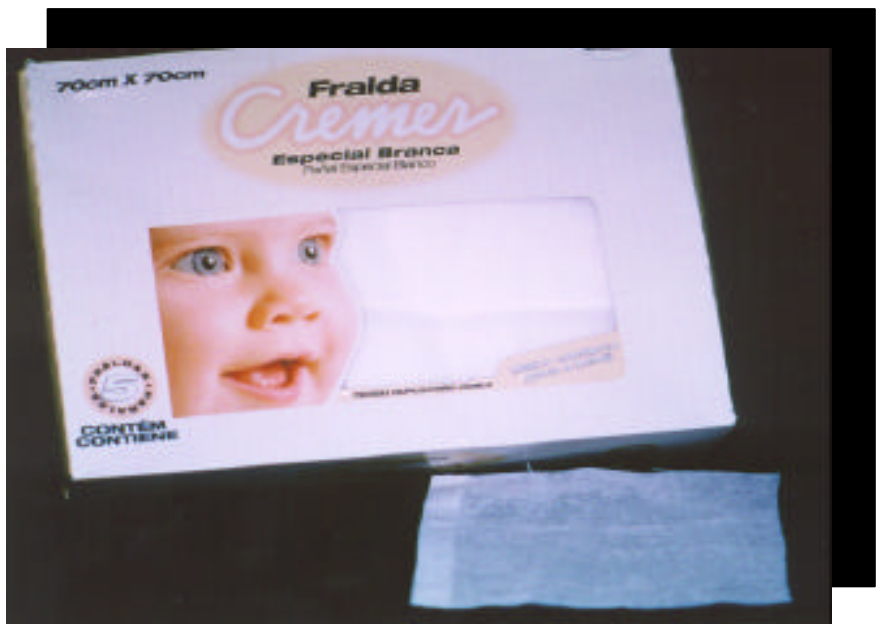

FIGURA 4 - Fralda Cremer Especial - Tecido Duplo, pedaço utilizado $15 \times 15 \mathrm{~cm}$.

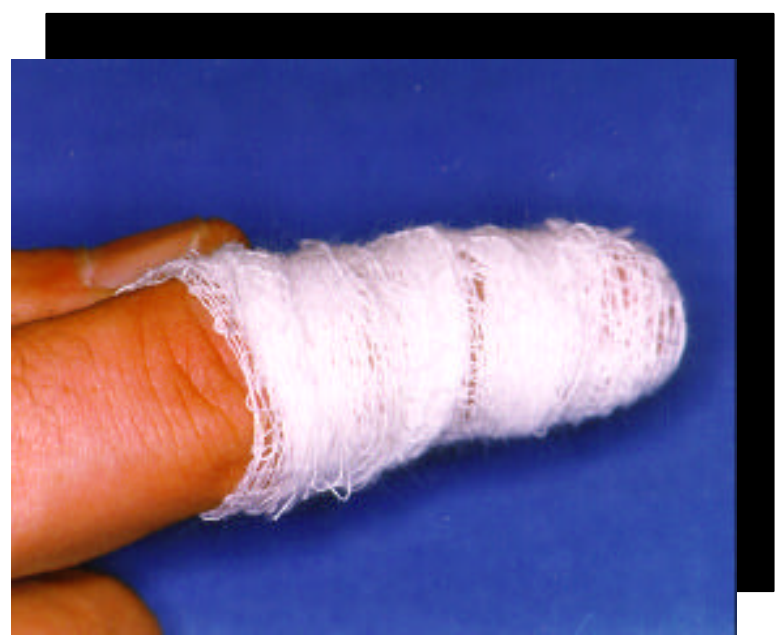

FIGURA 5 - Gaze enrolada no dedo do responsável pela higiene,

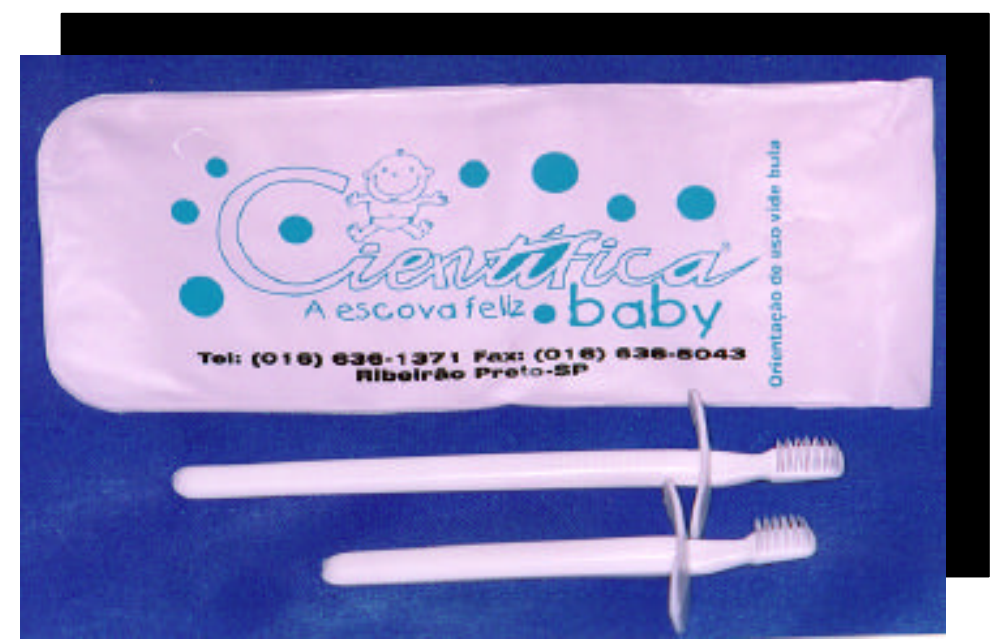
pronta para uso.

FIGURA 6 - Escova dental monobloco Científica Baby.
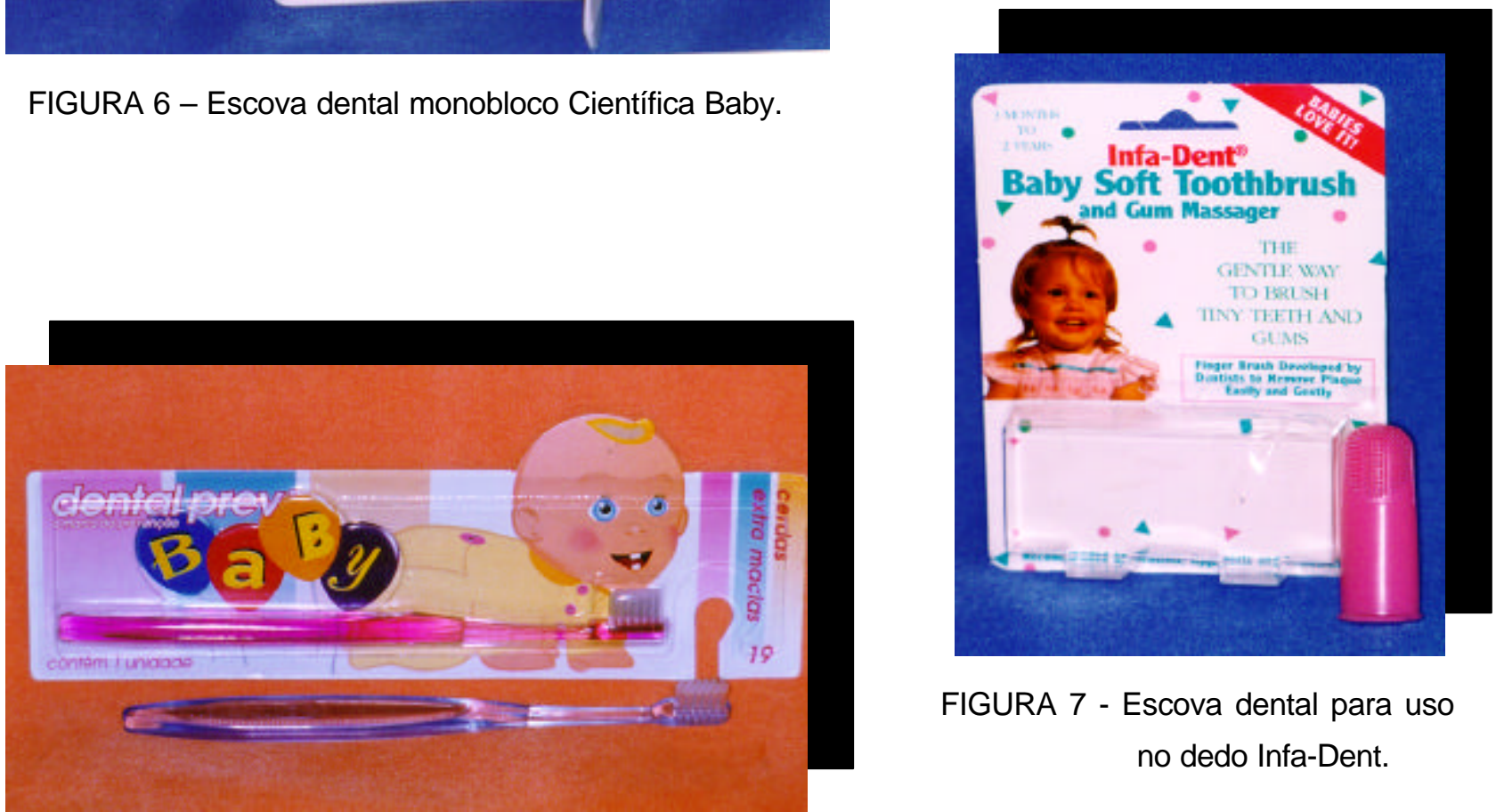

FIGURA 7 - Escova dental para uso no dedo Infa-Dent.

FIGURA 8 - Escova dental Dental Prev Baby. 


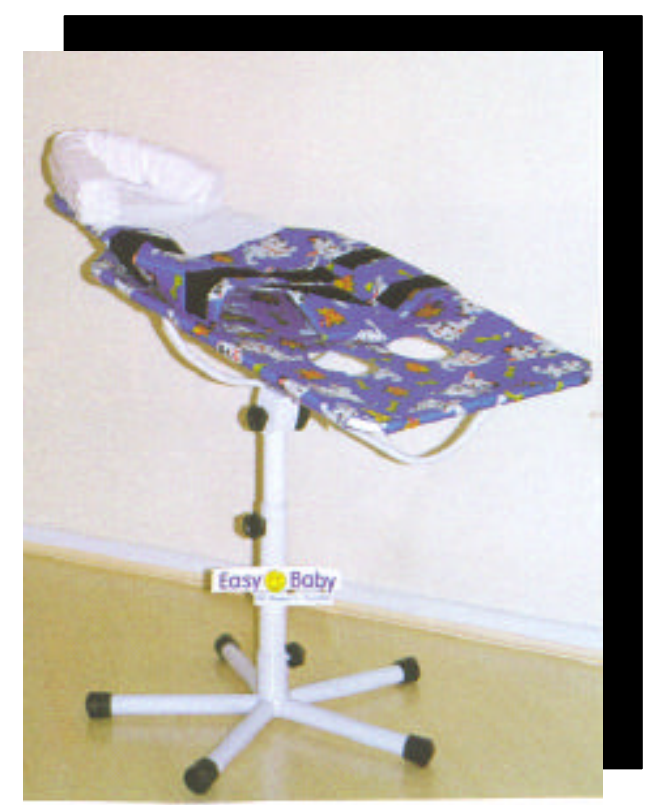

FIGURA 9 - Maca odontopediátrica Easy Baby.

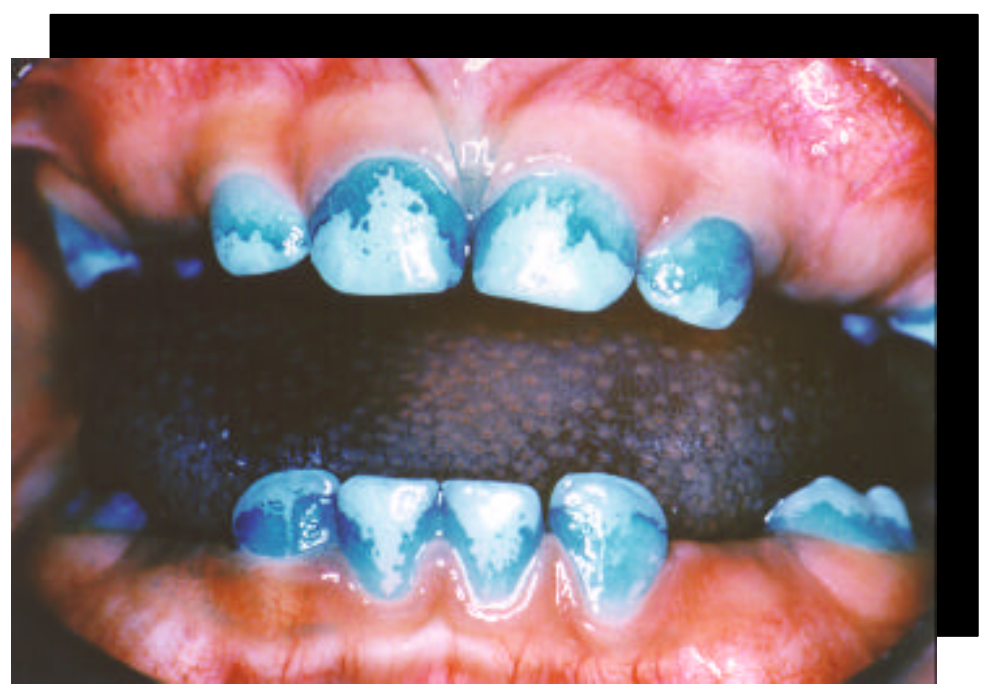

FIGURA 10 - Placa bacteriana corada pela solução evidenciadora Verde de Malaquita 0,6\%.

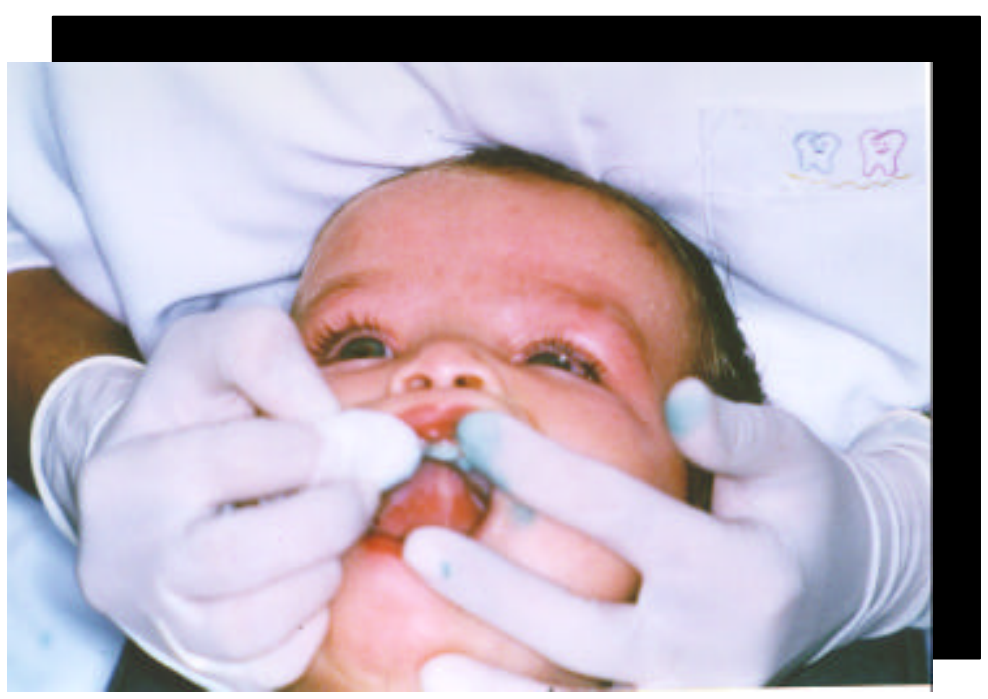

FIGURA 12 - Higiene sendo realizada pelo Odontopediatra, posicionado atrás da cabeça da criança

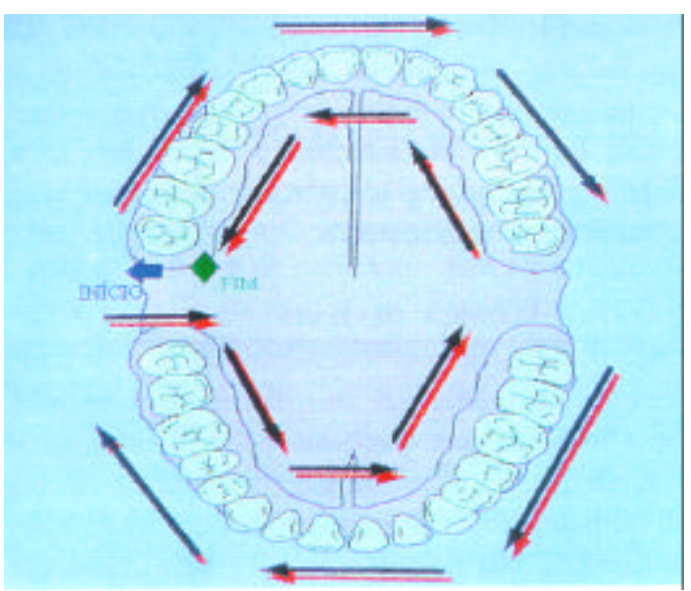

FIGURA 13 - Seqüência seguida durante a realização da higiene bucal. 


\subsection{3 - Avaliação comportamental do bebê}

Durante a realização da higienização bucal com todos os métodos testados, o bebê teve seu comportamento avaliado de acordo com a seguinte escala:

Paciente não colaborador (NC): recusa ao tratamento, resiste , é hostil. Apresenta extremo pavor, birra, choro, tentativa de fuga.

Paciente parcialmente colaborador (PC): aceita parcialmente 0 tratamento, choro de pouca intensidade, usando táticas protelatórias ou de envolvimento mas com alguma vontade de cooperar.

Paciente colaborador (C): sem nenhum problema de aceitação do tratamento, comportando-se bem e atendendo às orientações do profissional.

Ao longo das sessões, observou-se a evolução da conduta da criança. Foi anotado evolução positiva quando constatou-se uma melhora no comportamento da criança, conduta inalterada quando o comportamento continuou o mesmo e evolução negativa quando da piora do comportamento da criança.

\section{4. - ANÁLISE ESTATÍSTICA DOS DADOS}

Para comparação dos grupos, devido à natureza dos dados (escores: não é uma escala com proporcionalidade), não se pode empregar os testes tradicionais. Foram utilizados os seguintes testes não paramétricos:

- Análise de variância de Friedman e Método de Dunn: para comparação dos diferentes tipos de tratamento para um mesmo grupo (amostra dependente). 
- Análise de variância de Friedman e Método de Student-NewmanKeuls: somente para comparar a redução de placa na face oclusal entre os diversos tratamentos testados, pois por haver uma quantidade grande de números 0 não foi possível a utilização do método de Dunn.

- Teste de Mann-Whitney: para comparação entre as situações independentes.

- Teste do Qui-quadrado: para comparar a evolução da conduta dos bebês nos dois grupos.

- Teste de Correlação de Spearman: para verificar a correlação entre a eficiência da escovação e o tempo gasto para tal.

A metodologia estatística incluiu também uma análise descritiva dos dados e as mesmas restrições são aplicadas a estatística descritiva quanto à caracterização dos dados por meio de uma medida de tendência central. Nesses casos o mais recomendado é que se utilize a mediana do conjunto descrito. Entretanto, como a média aritmética é uma medida mais usual e mais familiar portanto à maioria dos leitores, decidimos apresentá-la com o intuito de facilitar a compreensão dos resultados, embora aquela medida não seja adequada para resumir conjuntos de dados de natureza ordinal.

O nível de significância mínimo adotado foi de 5\% para todos os testes. 
5. RESULTADOS 


\section{RESULTADOS}

Os resultados deste trabalho encontram-se nas Tabelas 3 a 15 e nas figuras 14 a 17.

Conforme descrito anteriormente, denominamos anteriores o sub-grupo composto por bebês com apenas dentes anteriores presentes na cavidade bucal e posteriores, aquele composto de crianças com pelo menos 2 dentes posteriores presente, além dos dentes anteriores.

Com relação aos Índices de placa, devemos considerar que nas superfícies lisas foi utilizado aquele proposto por Quigley; Hein, e nas superfícies oclusais o de Mestrinho; Carvalho; Figueiredo, ambos descritos anteriormente.

TABELA 3 - Índice de placa médio ( \pm d.p.) das superfícies lisas (Índice de Quigley; Hein) observado ao primeiro exame dos pacientes (antes da primeira profilaxia), de acordo com o grupo e subgrupo.

\begin{tabular}{lcc}
\hline Subgrupo & $\begin{array}{c}\text { GRUPO A } \\
\text { PACIENTES DA CLÍNICA DE } \\
\text { BEBÊS }\end{array}$ & $\begin{array}{c}\text { GRUPO B } \\
\text { PACIENTES DA CRECHE MONTEIRO } \\
\text { LOBATO }\end{array}$ \\
\hline ANTERIORES & $4,25( \pm 0,87)$ & $4,12( \pm 0,46)$ \\
POSTERIORES & $3,95( \pm 1,02)$ & $3,78( \pm 0,52)$ \\
\hline
\end{tabular}

A análise estatística demonstrou não haver diferença significativa entre os grupos. 
TABELA 4 - Índice de placa médio inicial ( \pm d.p.) e final ( \pm d.p.), redução média no índice de placa ( \pm d.p.), porcentagem média de redução no índice de placa, quando a fralda foi utilizada para a higienização, tanto para o grupo das mães quanto para o grupo onde o cirurgião dentista realizou a higiene bucal.

\begin{tabular}{|c|c|c|c|c|c|c|}
\hline & GRUPO & $\begin{array}{c}\text { ÍNDICE DE } \\
\text { PLACA MÉDIO } \\
\text { INICIAL } \\
( \pm \text { d.p. }) \\
\end{array}$ & $\begin{array}{c}\text { ÍNDICE DE } \\
\text { PLACA MÉDIO } \\
\text { FINAL } \\
( \pm \text { d. p. }) \\
\end{array}$ & $\begin{array}{c}\text { REDUÇÃO } \\
\text { MÉDIA NO } \\
\text { ÍNDICE DE } \\
\text { PLACA } \\
( \pm \text { d. p.) }\end{array}$ & $\begin{array}{c}\text { \% MÉDIA DE } \\
\text { REDUÇÃO NO } \\
\text { ÍNDICE DE } \\
\text { PLACA }\end{array}$ & $\mathrm{N}$ \\
\hline $\begin{array}{l}\text { m } \\
\text { O } \\
\stackrel{1}{1} \\
\dot{\omega}\end{array}$ & Anteriores & $\begin{array}{c}3,75 \\
( \pm 0,51)\end{array}$ & $\begin{array}{c}3,19 \\
( \pm 0,58)\end{array}$ & $\begin{array}{c}0,56 \\
( \pm 0,44)\end{array}$ & 14,85 & 13 \\
\hline $\begin{array}{l}\text { 岀 } \\
\text { 岁 } \\
\underline{0} \\
\underline{0}\end{array}$ & $\begin{array}{c}\text { Faces } \\
\text { livres } \\
\text { Posteriores }\end{array}$ & $\begin{array}{c}3,43 \\
( \pm 0,37)\end{array}$ & $\begin{array}{c}3,13 \\
( \pm 0,42)\end{array}$ & $\begin{array}{c}0,29 \\
( \pm 0,20)\end{array}$ & 8,58 & 23 \\
\hline 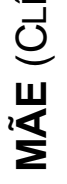 & $\begin{array}{c}\text { Face } \\
\text { Oclusal } \\
\text { Posteriores }\end{array}$ & $\begin{array}{c}2,38 \\
( \pm 0,46)\end{array}$ & $\begin{array}{c}2,34 \\
( \pm 0,47)\end{array}$ & $\begin{array}{c}0,04 \\
( \pm 0,15)\end{array}$ & 1,47 & 23 \\
\hline $\begin{array}{l}\widehat{0} \\
\frac{1}{1} \\
0 \\
\text { ô }\end{array}$ & Anteriores & $\begin{array}{c}3,77 \\
( \pm 0,65)\end{array}$ & $\begin{array}{c}2,18 \\
( \pm 0,70)\end{array}$ & $\begin{array}{c}0,95 \\
( \pm 0,28)\end{array}$ & 26,00 & 10 \\
\hline 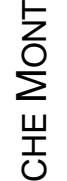 & $\begin{array}{c}\text { Faces } \\
\text { livres } \\
\text { Posteriores }\end{array}$ & $\begin{array}{c}3,40 \\
( \pm 0,63)\end{array}$ & $\begin{array}{c}2,71 \\
( \pm 0,66)\end{array}$ & $\begin{array}{c}0,68 \\
( \pm 0,23)\end{array}$ & 20,65 & 17 \\
\hline 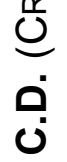 & $\begin{array}{c}\text { Face } \\
\text { Oclusal } \\
\text { Posteriores }\end{array}$ & $\begin{array}{c}2,33 \\
( \pm 0,52)\end{array}$ & $\begin{array}{c}2,31 \\
( \pm 0,50)\end{array}$ & $\begin{array}{c}0,02 \\
( \pm 0,04)\end{array}$ & 0,44 & 17 \\
\hline
\end{tabular}


TABELA 5 - Índice de placa médio inicial ( \pm d.p.) e final ( \pm d.p.), redução média no índice de placa ( \pm d.p.), porcentagem média de redução no índice de placa, quando a gaze foi utilizada para a higienização, tanto para o grupo das mães quanto para o grupo onde o cirurgião dentista realizou a higiene bucal.

\begin{tabular}{|c|c|c|c|c|c|c|}
\hline & GRUPO & $\begin{array}{c}\text { ÍNDICE DE } \\
\text { PLACA MÉDIO } \\
\text { INICIAL } \\
( \pm \text { d. p. }) \\
\end{array}$ & $\begin{array}{c}\text { ÍNDICE DE } \\
\text { PLACA MÉDIO } \\
\text { FINAL } \\
( \pm \text { d. p. })\end{array}$ & $\begin{array}{c}\text { REDUÇÃO } \\
\text { MÉDIA NO } \\
\text { ÍNDICE DE } \\
\text { PLACA } \\
( \pm \text { d. p.) }\end{array}$ & $\begin{array}{c}\text { \% MÉDIA DE } \\
\text { REDUÇÃO NO } \\
\text { ÍNDICE DE } \\
\text { PLACA }\end{array}$ & $\mathrm{N}$ \\
\hline $\begin{array}{l}\text { m } \\
\text { O } \\
\stackrel{1}{1} \\
\dot{\omega}\end{array}$ & Anteriores & $\begin{array}{c}3,58 \\
( \pm 0,82)\end{array}$ & $\begin{array}{c}3,19 \\
( \pm 0,89)\end{array}$ & $\begin{array}{c}0,40 \\
( \pm 0,22)\end{array}$ & 12,59 & 13 \\
\hline $\begin{array}{l}\text { 岀 } \\
\text { 岁 } \\
\underline{0} \\
\underline{0}\end{array}$ & $\begin{array}{c}\text { Faces } \\
\text { livres } \\
\text { Posteriores }\end{array}$ & $\begin{array}{c}3,37 \\
( \pm 0,36)\end{array}$ & $\begin{array}{c}3,16 \\
( \pm 0,34)\end{array}$ & $\begin{array}{c}0,21 \\
( \pm 0,16)\end{array}$ & 5,84 & 23 \\
\hline 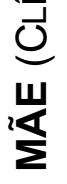 & $\begin{array}{c}\text { Face } \\
\text { Oclusal } \\
\text { Posteriores }\end{array}$ & $\begin{array}{c}2,47 \\
( \pm 0,58)\end{array}$ & $\begin{array}{c}2,44 \\
( \pm 0,56)\end{array}$ & $\begin{array}{c}0,03 \\
( \pm 0,10)\end{array}$ & 0,76 & 23 \\
\hline 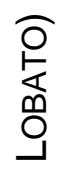 & Anteriores & $\begin{array}{c}3,58 \\
( \pm 0,77)\end{array}$ & $\begin{array}{c}2,83 \\
( \pm 0,80)\end{array}$ & $\begin{array}{c}0,76 \\
( \pm 0,24)\end{array}$ & 22,12 & 10 \\
\hline 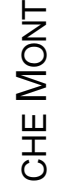 & $\begin{array}{c}\text { Faces } \\
\text { livres } \\
\text { Posteriores }\end{array}$ & $\begin{array}{c}3,09 \\
( \pm 0,57)\end{array}$ & $\begin{array}{c}2,52 \\
( \pm 0,56)\end{array}$ & $\begin{array}{c}0,55 \\
( \pm 0,19)\end{array}$ & 18,21 & 17 \\
\hline 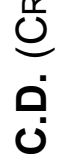 & $\begin{array}{c}\text { Face } \\
\text { Oclusal } \\
\text { Posteriores }\end{array}$ & $\begin{array}{c}2,18 \\
( \pm 0,38)\end{array}$ & $\begin{array}{c}2,17 \\
( \pm 0,38)\end{array}$ & $\begin{array}{c}0,01 \\
( \pm 0,03)\end{array}$ & 0,27 & 17 \\
\hline
\end{tabular}


TABELA 6 - Índice de placa médio inicial $( \pm$ d. p.) e final $( \pm$ d. p.), redução média no índice de placa $( \pm$ d. p.), porcentagem média de redução no índice de placa, quando a escova dental Científica Baby foi utilizada para a higienização, tanto para o grupo das mães quanto para o grupo onde o cirurgião dentista realizou a higiene bucal.

\begin{tabular}{|c|c|c|c|c|c|c|}
\hline & GRUPO & $\begin{array}{c}\text { ÍNDICE DE } \\
\text { PLACA MÉDIO } \\
\text { INICIAL } \\
( \pm \text { d. p. }) \\
\end{array}$ & $\begin{array}{c}\text { ÍNDICE DE } \\
\text { PLACA MÉDIO } \\
\text { FINAL } \\
( \pm \text { d. p. })\end{array}$ & $\begin{array}{c}\text { REDUÇÃO } \\
\text { MÉDIA NO } \\
\text { ÍNDICE DE } \\
\text { PLACA } \\
( \pm \text { d. p.) }\end{array}$ & $\begin{array}{c}\text { \% MÉDIA DE } \\
\text { REDUÇÃO NO } \\
\text { ÍNDICE DE } \\
\text { PLACA }\end{array}$ & $N$ \\
\hline 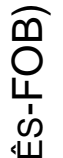 & Anteriores & $\begin{array}{c}3,59 \\
( \pm 0,73)\end{array}$ & $\begin{array}{c}3,22 \\
( \pm 0,67)\end{array}$ & $\begin{array}{c}0,37 \\
( \pm 0,27)\end{array}$ & 11,76 & 13 \\
\hline 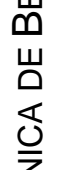 & $\begin{array}{c}\text { Faces } \\
\text { livres } \\
\text { Posteriores }\end{array}$ & $\begin{array}{c}3,38 \\
( \pm 0,46)\end{array}$ & $\begin{array}{c}3,11 \\
( \pm 0,41)\end{array}$ & $\begin{array}{c}0,28 \\
( \pm 0,20)\end{array}$ & 8,28 & 23 \\
\hline 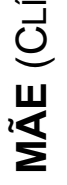 & $\begin{array}{c}\text { Face } \\
\text { Oclusal } \\
\text { Posteriores }\end{array}$ & $\begin{array}{c}2,50 \\
( \pm 0,48)\end{array}$ & $\begin{array}{c}2,29 \\
( \pm 0,48)\end{array}$ & $\begin{array}{c}0,21 \\
( \pm 0,30)\end{array}$ & 7,51 & 23 \\
\hline 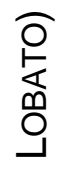 & Anteriores & $\begin{array}{c}3,76 \\
( \pm 0,77)\end{array}$ & $\begin{array}{c}3,15 \\
( \pm 0,88)\end{array}$ & $\begin{array}{c}0,61 \\
( \pm 0,37)\end{array}$ & 17,48 & 10 \\
\hline 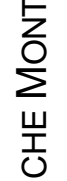 & $\begin{array}{c}\text { Faces } \\
\text { livres } \\
\text { Posteriores }\end{array}$ & $\begin{array}{c}3,42 \\
( \pm 0,53)\end{array}$ & $\begin{array}{c}2,89 \\
( \pm 0,52)\end{array}$ & $\begin{array}{c}0,54 \\
( \pm 0,15)\end{array}$ & 16,42 & 17 \\
\hline$\frac{\text { Un }}{0}$ & $\begin{array}{c}\text { Face } \\
\text { Oclusal } \\
\text { Posteriores }\end{array}$ & $\begin{array}{c}2,25 \\
( \pm 0,37)\end{array}$ & $\begin{array}{c}2,08 \\
( \pm 0,40)\end{array}$ & $\begin{array}{c}0,18 \\
( \pm 0,15)\end{array}$ & 7,92 & 17 \\
\hline
\end{tabular}


TABELA 7 - Índice de placa médio inicial $( \pm$ d. p.) e final $( \pm$ d. p.), redução média no índice de placa $( \pm$ d. p.), porcentagem média de redução no índice de placa, quando a escova dental de dedo InfaDent foi utilizada para a higienização, tanto para o grupo das mães quanto para o grupo onde o cirurgião dentista realizou a higiene bucal.

\begin{tabular}{|c|c|c|c|c|c|c|}
\hline & GRUPO & $\begin{array}{c}\text { ÍNDICE DE } \\
\text { PLACA MÉDIO } \\
\text { INICIAL } \\
( \pm \text { d. p. }) \\
\end{array}$ & $\begin{array}{l}\text { ÍNDICE DE } \\
\text { PLACA MÉDIO } \\
\text { FINAL } \\
( \pm \text { d. p. }) \\
\end{array}$ & $\begin{array}{c}\text { REDUÇÃO } \\
\text { MÉDIA NO } \\
\text { ÍNDICE DE } \\
\text { PLACA } \\
( \pm \text { d. p.) }\end{array}$ & $\begin{array}{c}\text { \% MÉDIA DE } \\
\text { REDUÇÃO NO } \\
\text { ÍNDICE DE } \\
\text { PLACA }\end{array}$ & $\mathrm{N}$ \\
\hline $\begin{array}{l}\widetilde{m} \\
\text { Oे } \\
\stackrel{1}{\dot{1}} \\
\dot{山}\end{array}$ & Anteriores & $\begin{array}{c}3,48 \\
( \pm 0,60)\end{array}$ & $\begin{array}{c}3,20 \\
( \pm 0,61)\end{array}$ & $\begin{array}{c}0,28 \\
( \pm 0,24)\end{array}$ & 8,10 & 13 \\
\hline 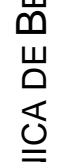 & $\begin{array}{c}\text { Faces } \\
\text { livres } \\
\text { Posteriores }\end{array}$ & $\begin{array}{c}3,43 \\
( \pm 0,45)\end{array}$ & $\begin{array}{c}3,24 \\
( \pm 0,47)\end{array}$ & $\begin{array}{c}0,18 \\
( \pm 0,12)\end{array}$ & 6,09 & 23 \\
\hline 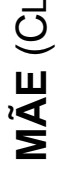 & $\begin{array}{c}\text { Face } \\
\text { Oclusal } \\
\text { Posteriores }\end{array}$ & $\begin{array}{c}2,53 \\
( \pm 0,65)\end{array}$ & $\begin{array}{c}2,48 \\
( \pm 0,71)\end{array}$ & $\begin{array}{c}0,05 \\
( \pm 0,17)\end{array}$ & 2,92 & 23 \\
\hline 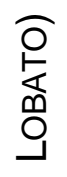 & Anteriores & $\begin{array}{c}3,92 \\
( \pm 0,54)\end{array}$ & $\begin{array}{c}3,85 \\
( \pm 0,55)\end{array}$ & $\begin{array}{c}0,08 \\
( \pm 0,14)\end{array}$ & 3,81 & 10 \\
\hline 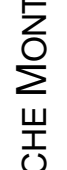 & $\begin{array}{c}\text { Faces } \\
\text { livres } \\
\text { Posteriores }\end{array}$ & $\begin{array}{c}3,22 \\
( \pm 0,63)\end{array}$ & $\begin{array}{c}3,13 \\
( \pm 0,63)\end{array}$ & $\begin{array}{c}0,08 \\
( \pm 0,07)\end{array}$ & 2,56 & 17 \\
\hline 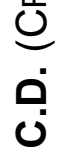 & $\begin{array}{c}\text { Face } \\
\text { Oclusal } \\
\text { Posteriores }\end{array}$ & $\begin{array}{c}2,15 \\
( \pm 0,51)\end{array}$ & $\begin{array}{c}2,15 \\
( \pm 0,51)\end{array}$ & $\begin{array}{c}0,00 \\
( \pm 0,00)\end{array}$ & 0,00 & 17 \\
\hline
\end{tabular}


TABELA 8 - Índice de placa médio inicial $( \pm$ d. p.) e final $( \pm$ d. p.), redução média no índice de placa $( \pm$ d. p.), porcentagem média de redução no índice de placa, quando a escova dental Dental Prev Baby foi utilizada para a higienização, tanto para o grupo das mães quanto para o grupo onde o cirurgião dentista realizou a higiene bucal.

\begin{tabular}{|c|c|c|c|c|c|c|}
\hline & GRUPO & $\begin{array}{l}\text { ÍNDICE DE } \\
\text { PLACA MÉDIO } \\
\text { INICIAL } \\
( \pm \text { d. p. }) \\
\end{array}$ & $\begin{array}{c}\text { ÍNDICE DE } \\
\text { PLACA MÉDIO } \\
\text { FINAL } \\
( \pm \text { d. p. }) \\
\end{array}$ & $\begin{array}{c}\text { REDUÇÃO } \\
\text { MÉDIA NO } \\
\text { ÍNDICE DE } \\
\text { PLACA } \\
( \pm \text { d. p.) }\end{array}$ & $\begin{array}{c}\text { \% MÉDIA DE } \\
\text { REDUÇÃO NO } \\
\text { ÍNDICE DE } \\
\text { PLACA }\end{array}$ & $\mathrm{N}$ \\
\hline 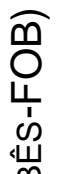 & Anteriores & $\begin{array}{c}3,64 \\
( \pm 0,65)\end{array}$ & $\begin{array}{c}2,96 \\
( \pm 0,69)\end{array}$ & $\begin{array}{c}0,68 \\
( \pm 0,28)\end{array}$ & 19,25 & 13 \\
\hline $\begin{array}{l}\text { 岗 } \\
\text { 岁 } \\
\mathbb{0} \\
\frac{0}{7}\end{array}$ & $\begin{array}{c}\text { Faces } \\
\text { livres } \\
\text { Posteriores }\end{array}$ & $\begin{array}{c}3,37 \\
( \pm 0,52)\end{array}$ & $\begin{array}{c}2,76 \\
( \pm 0,67)\end{array}$ & $\begin{array}{c}0,59 \\
( \pm 0,30)\end{array}$ & 18,39 & 23 \\
\hline 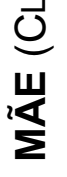 & $\begin{array}{c}\text { Face } \\
\text { Oclusal } \\
\text { Posteriores }\end{array}$ & $\begin{array}{c}2,53 \\
( \pm 0,53)\end{array}$ & $\begin{array}{c}2,06 \\
( \pm 0,67)\end{array}$ & $\begin{array}{c}0,45 \\
( \pm 0,43)\end{array}$ & 18,82 & 23 \\
\hline $\begin{array}{l}\text { o } \\
\text { eq } \\
\text { ô } \\
\text { a }\end{array}$ & Anteriores & $\begin{array}{c}3,75 \\
( \pm 0,58)\end{array}$ & $\begin{array}{c}2,08 \\
( \pm 0,41)\end{array}$ & $\begin{array}{c}1,68 \\
( \pm 0,35)\end{array}$ & 44,65 & 10 \\
\hline$\sum_{\substack{W \\
\text { บั }}}^{Z}$ & $\begin{array}{c}\text { Faces } \\
\text { livres } \\
\text { Posteriores }\end{array}$ & $\begin{array}{c}3,52 \\
( \pm 0,61)\end{array}$ & $\begin{array}{c}2,31 \\
( \pm 0,57)\end{array}$ & $\begin{array}{c}1,20 \\
( \pm 0,32)\end{array}$ & 34,66 & 17 \\
\hline 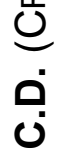 & $\begin{array}{c}\text { Face } \\
\text { Oclusal } \\
\text { Posteriores }\end{array}$ & $\begin{array}{c}2,32 \\
( \pm 0,36)\end{array}$ & $\begin{array}{c}1,70 \\
( \pm 0,59)\end{array}$ & $\begin{array}{c}0,62 \\
( \pm 0,31)\end{array}$ & 28,81 & 17 \\
\hline
\end{tabular}


TABELA 9 - Porcentagem média ( \pm d. p.) da redução do índice de placa para os diferentes tipos de higienização bucal realizadas pelas mães.

\begin{tabular}{|c|c|c|c|c|c|}
\hline $\begin{array}{l}\text { Dispositivos } \\
\text { SUB-GRUPO }\end{array}$ & FRALDA & GAZE & $\begin{array}{c}\text { ESCOVA } \\
\text { DENTAL } \\
\text { CIENTÍFICA } \\
\text { BABY } \\
\end{array}$ & $\begin{array}{c}\text { ESCOVA } \\
\text { DENTAL DE } \\
\text { DEDO } \\
\text { INFA-DENT } \\
\end{array}$ & $\begin{array}{c}\text { ESCOVA } \\
\text { DENTAL } \\
\text { DENTAL } \\
\text { PREV BABY } \\
\end{array}$ \\
\hline Anteriores & $\begin{array}{c}14,85 \\
( \pm 10,57)\end{array}$ & $\begin{array}{c}12,58 \\
( \pm 9,64)\end{array}$ & $\begin{array}{c}11,76 \\
( \pm 8,34)\end{array}$ & $\begin{array}{c}8,11 \\
(6,67)\end{array}$ & $\begin{array}{c}19,25 \\
( \pm 8,32)\end{array}$ \\
\hline $\begin{array}{l}\text { Posteriores } \\
\text { Faces livres }\end{array}$ & $\begin{array}{c}8,58 \\
( \pm 5,88)\end{array}$ & $\begin{array}{c}5,84 \\
( \pm 4,33)\end{array}$ & $\begin{array}{c}8,28 \\
( \pm 5,36)\end{array}$ & $\begin{array}{c}6,09 \\
( \pm 4,65)\end{array}$ & $\begin{array}{c}18,39 \\
( \pm 10,97)\end{array}$ \\
\hline $\begin{array}{l}\text { Posteriores } \\
\text { Face oclusal }\end{array}$ & $\begin{array}{c}1,47 \\
( \pm 5,79)\end{array}$ & $\begin{array}{c}0,76 \\
( \pm 2,51)\end{array}$ & $\begin{array}{c}7,51 \\
( \pm 11,90)\end{array}$ & $\begin{array}{c}2,92 \\
( \pm 9,20)\end{array}$ & $\begin{array}{c}18,82 \\
( \pm 19,72)\end{array}$ \\
\hline
\end{tabular}

Para o grupo de bebês que apresentavam apenas dentes anteriores, houve diferença estatisticamente significante somente entre a higienização feita com a escova dental Dental Prev Baby e a escova Científica Baby e entre a Dental Prev Baby e a escova Infa-Dent $(p<0,05)$, de modo que a escova convencional Dental Prev Baby foi superior às outras duas citadas e a escova Infa-Dent apresentou o pior desempenho.

Para o grupo com a presença de dentes posteriores, houve diferença estatisticamente significante entre a escova dental Dental Prev Baby e todos os outros tratamentos $(p<0,05)$, sendo que esta apresentou o melhor desempenho. Com relação à superfície oclusal a mesma situação descrita acima foi observada.

Quando comparada a eficácia dos diferentes métodos entre os 2 subgrupos (anteriores e posteriores), foi observada diferença significativa somente quando a fralda e a gaze foram utilizadas $(p<0,05)$, sendo que ambas 
apresentaram desempenho semelhante ao da escova Dental Prev Baby no sub-grupo anteriores.

As porcentagens de redução no índice de placa conseguidas pelas mães, de acordo com os dispositivos utilizados, podem ser melhor visualizadas no gráfico abaixo (Fig.14).

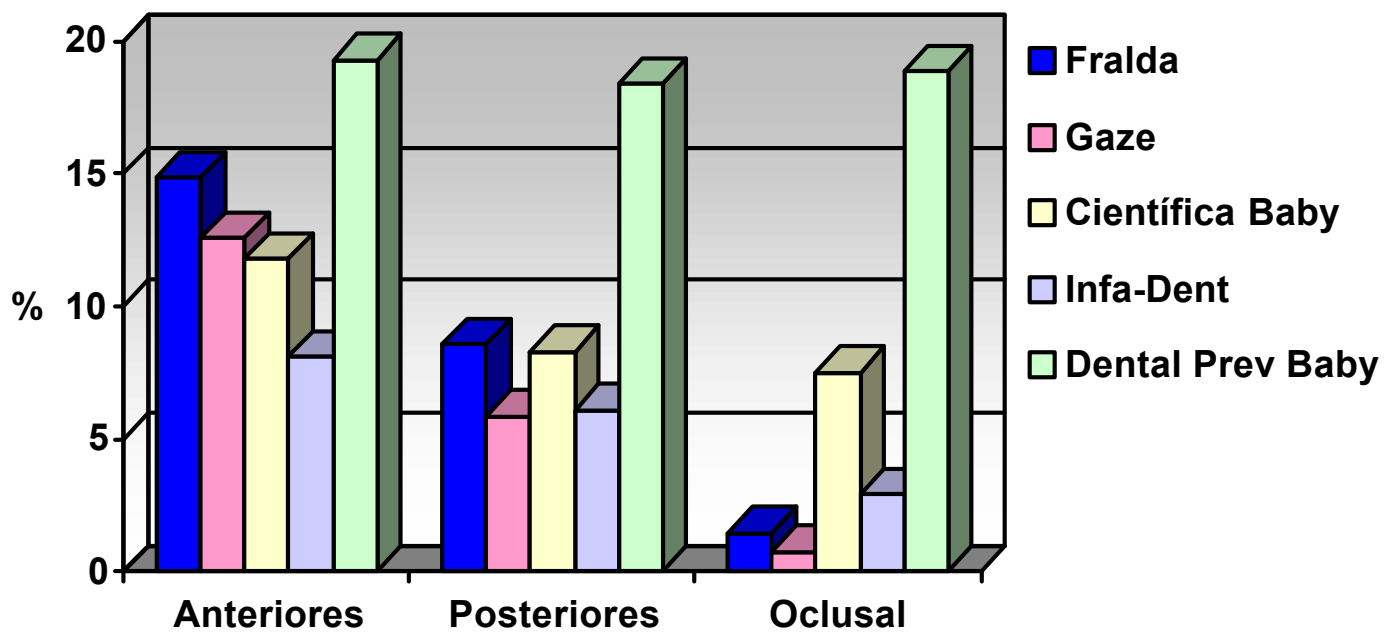

FIGURA 14 - Gráfico que representa a porcentagem média da redução do índice de placa para os diferentes tipos de higienização bucal realizadas pelas mães. 
TABELA 10 - Porcentagem média ( \pm d. p.) da redução do índice de placa para os diferentes tipos de higienização bucal realizadas pelo Odontopediatra.

\begin{tabular}{cccccc}
\hline DisposItIVOS & FRALDA & GAZE & $\begin{array}{c}\text { ESCOVA } \\
\text { DENTAL } \\
\text { CIENTÍFICA } \\
\text { BABY }\end{array}$ & $\begin{array}{c}\text { ESCOVA } \\
\text { DENTAL DE } \\
\text { DEDO } \\
\text { INFA-DENT }\end{array}$ & $\begin{array}{c}\text { ESCOVA } \\
\text { DENTAL } \\
\text { DENTAL } \\
\text { PREV BABY }\end{array}$ \\
\hline Anteriores & $\begin{array}{c}25,95 \\
( \pm 9,08)\end{array}$ & $\begin{array}{c}22,12 \\
( \pm 7,94)\end{array}$ & $\begin{array}{c}17,48 \\
( \pm 12,10)\end{array}$ & $\begin{array}{c}1,98 \\
( \pm 3,80)\end{array}$ & $\begin{array}{c}44,65 \\
( \pm 7,08)\end{array}$ \\
Posteriores & 20,65 & 18,22 & 16,42 & 2,56 & 34,67 \\
Faces livres & $( \pm 7,61)$ & $( \pm 6,13)$ & $( \pm 5,01)$ & $( \pm 2,23)$ & $( \pm 9,23)$ \\
Posteriores & 0,44 & 0,26 & 7,91 & 0,00 & 28,80 \\
Face oclusal & $( \pm 1,25)$ & $( \pm 1,10)$ & $( \pm 7,39)$ & $( \pm 0,00)$ & $( \pm 14,81)$ \\
\hline
\end{tabular}

A análise estatística mostrou diferença significante no grupo de bebês com apenas dentes anteriores, entre a Dental Prev Baby e os outros dispositivos e entre a Infa-Dent e os outros dispositivos.

Para o grupo que já apresentava dentes posteriores houve diferença estatisticamente significante entre a Dental Prev Baby e os outros dispositivos e entre a fralda e a Infa-Dent, sendo que o melhor desempenho foi apresentado pela escova Dental Prev Baby, seguido pela fralda. A escova Infa-Dent apresentou o pior desempenho.

Quanto à face oclusal, também foi observada diferença estatisticamente significante entre a Dental Prev Baby e os outros dispositivos e entre a Científica Baby e os outros dispositivos, sendo que mais uma vez o melhor desempenho foi mostrado pela escova Dental Prev Baby, seguida da escova Científica Baby. 
Quando comparada a eficácia dos diferentes métodos nos 2 grupos (anteriores e posteriores), foi observada diferença significativa somente quando a fralda e a gaze foram utilizadas $(p<0,05)$.

As porcentagens de redução no índice de placa através da higienização promovida pelo Odontopediatra, de acordo com os dispositivos utilizados, podem ser melhor visualizadas no gráfico abaixo (Fig.15).

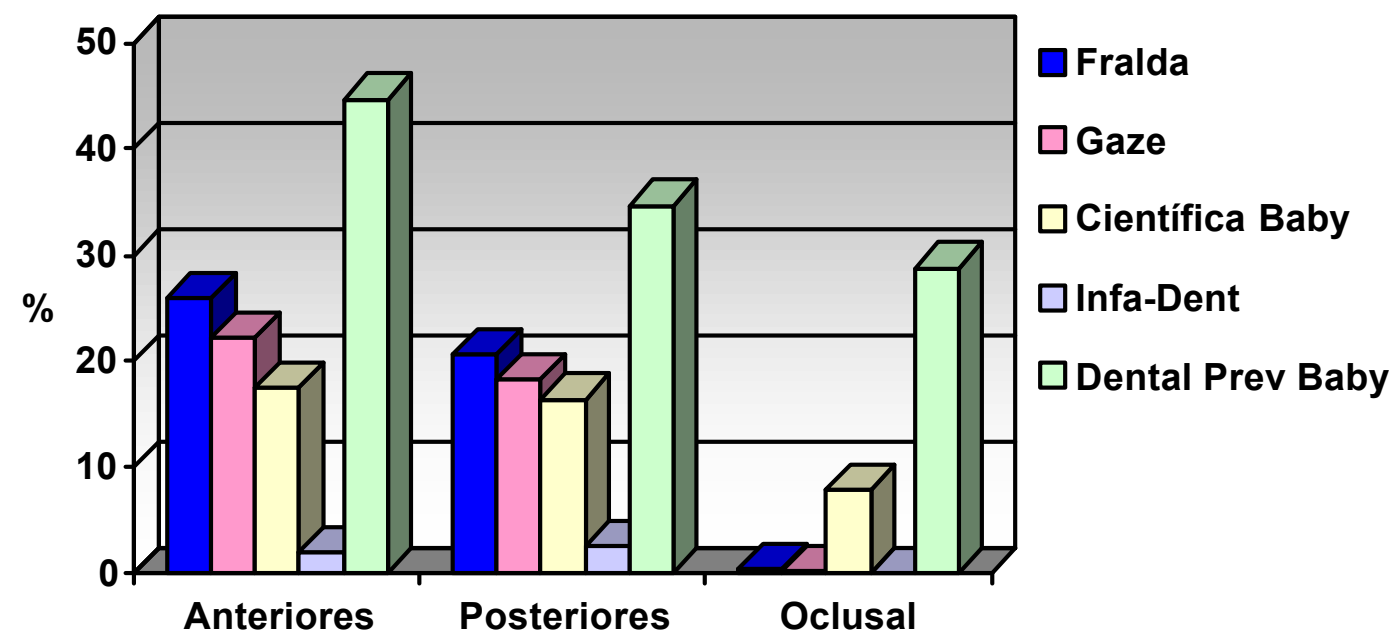

FIGURA 15 - Gráfico que representa a porcentagem média da redução do índice de placa para os diferentes tipos de higienização bucal realizadas pelo Odontopediatra 
TABELA 11 - Porcentagem média ( \pm d. p.) da redução do índice de placa durante a higiene bucal realizada pelas mães e pelo Odontopediatra (média da redução conseguida com o uso de todos os métodos).

\begin{tabular}{lcl}
\hline Subgrupo & MÃES & C.D. \\
\hline ANTERIORES & $13,06( \pm 8,72)$ & $22,44( \pm 7,85)$ \\
POSTERIORES & $9,43( \pm 6,23)$ & $18,50( \pm 6,04)$ \\
\hline
\end{tabular}

Quando comparadas as porcentagens médias de redução no índice de placa obtidos através da higienização realizada pelas mães e pelo Odontopediatras, a análise estatística demonstrou haver diferença significativa entre os dois grupos, sendo que a higiene bucal realizada pelo Odontopediatra conseguiu maior porcentagem de redução. Esta diferença pode ser melhor visualizada no gráfico a seguir (Fig. 16).

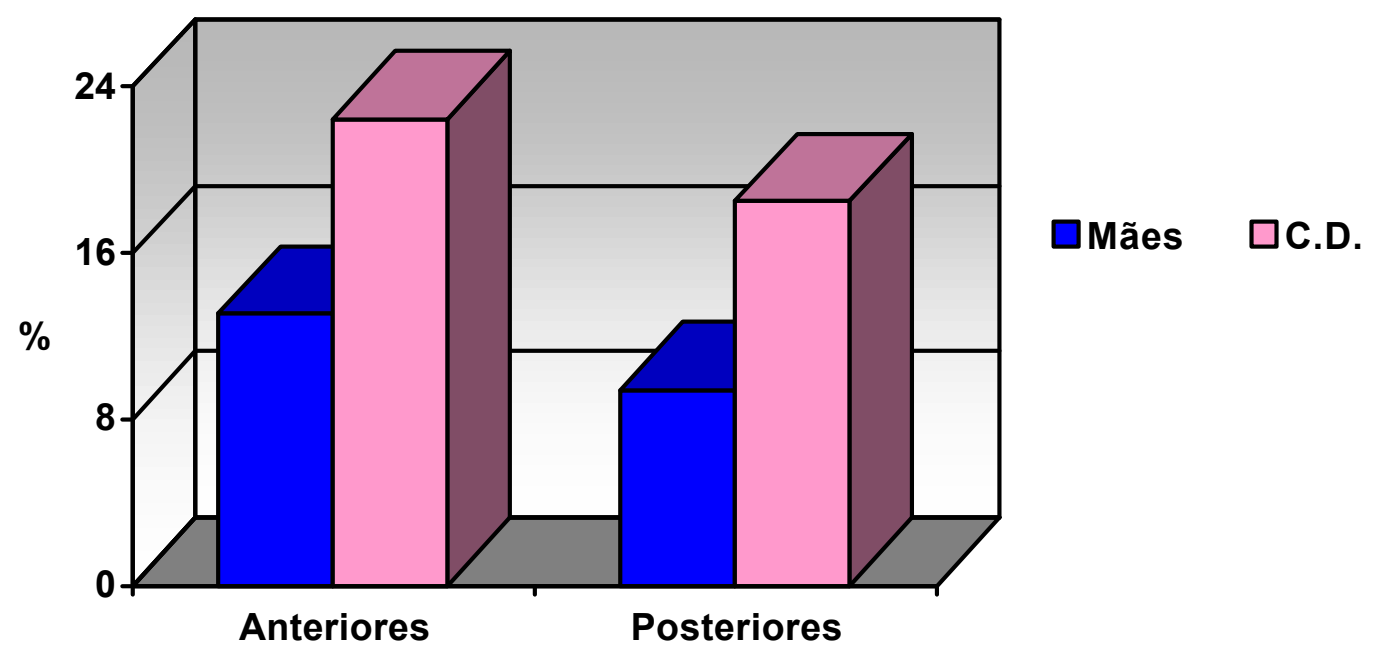

FIGURA 16 - Gráfico comparativo da redução do índice de placa (\%) durante a higiene bucal realizada pelas mães e pelo Odontopediatra (média da redução conseguida com o uso de todos os métodos). 
TABELA 12 - Tempo (em segundos) médio ( \pm d. p.) gasto pelas mães para realização da higiene bucal nos bebês, conforme o dispositivo utilizado.

\begin{tabular}{cccccc}
\hline DISPOSITIVOS & GRALDA & GAZE & $\begin{array}{c}\text { ESCOVA } \\
\text { DENTAL } \\
\text { CIENTÍFICA } \\
\text { BABY }\end{array}$ & $\begin{array}{c}\text { ESCOVA } \\
\text { DENTAL DE } \\
\text { DEDO } \\
\text { INFA-DENT }\end{array}$ & $\begin{array}{c}\text { ESCOVA } \\
\text { DENTAL } \\
\text { DENTAL } \\
\text { PREV BABY }\end{array}$ \\
\hline Anteriores & $\begin{array}{c}64,0 \\
( \pm 22,3)\end{array}$ & $\begin{array}{c}69,3 \\
( \pm 29,5)\end{array}$ & $\begin{array}{c}81,4 \\
( \pm 38,9)\end{array}$ & $\begin{array}{c}76,2 \\
( \pm 44,2)\end{array}$ & $\begin{array}{c}86,3 \\
( \pm 39,9)\end{array}$ \\
Posteriores & 111,5 & $\begin{array}{c}95,5 \\
( \pm 62,2)\end{array}$ & $\begin{array}{c}138,8 \\
( \pm 53,4)\end{array}$ & $\begin{array}{c}( \pm 68,8) \\
( \pm 54,4)\end{array}$ & $\begin{array}{c}129,0 \\
( \pm 73,3)\end{array}$ \\
\hline
\end{tabular}

A análise estatística não mostrou diferença significativa entre os tempos utilizados de acordo com os dispositivos, para os bebês com dentes anteriores. Para o grupo com dentes posteriores, houve diferença significativa entre os tempos utilizados com gaze e Infa-Dent e com gaze e Científica Baby. 
Para avaliar se a efetividade da remoção de placa pela higiene bucal está relacionada com o tempo gasto para tal, aplicou-se um teste estatístico de correlação. O teste analisou separadamente o grupo de bebês com dentes anteriores e o grupo com posteriores, e verificou existir uma fraca correlação entre tempo de escovação e efetividade da remoção de placa, em ambos os grupos. Os dados utilizados para este teste foram a média das porcentagens de redução do índice de placa conseguida por todos os dispositivos e a média dos tempos gasto na higiene com todos os dispositivos.

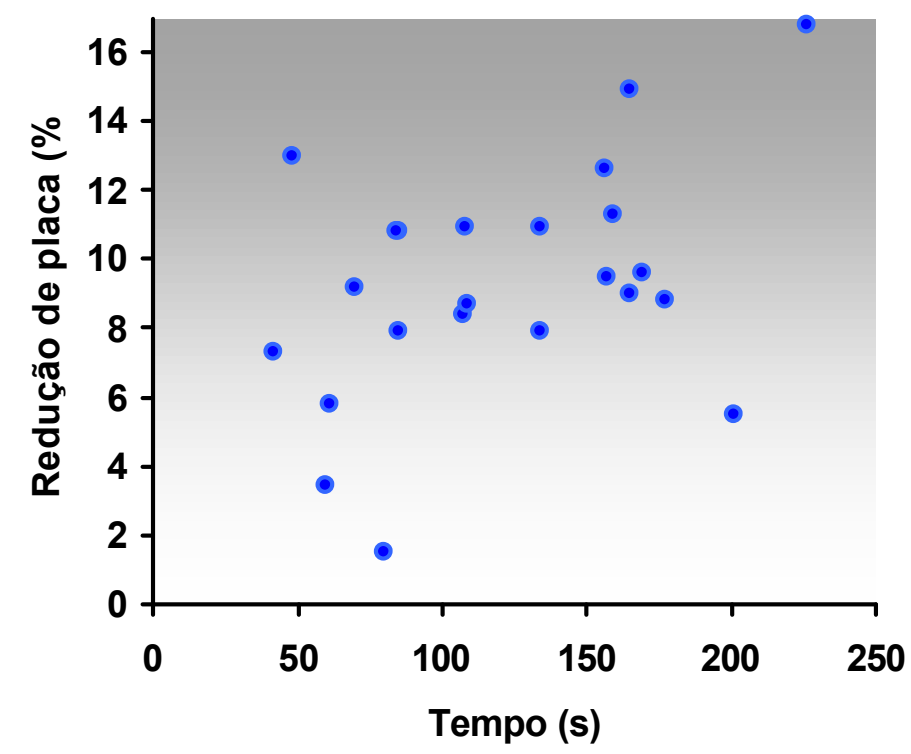

FIGURA 17 - Gráfico da correlação entre a média de redução do índice de placa e o tempo gasto para realização da higiene pelas mães, no grupo de bebês com dentes posteriores. 
TABELA 13 - Preferência das mães em relação aos dispositivos por elas utilizados para realização da higiene bucal nos bebês.

\begin{tabular}{|c|c|c|c|c|c|c|}
\hline & FRALDA & GAZE & $\begin{array}{c}\text { ESCOVA } \\
\text { DENTAL } \\
\text { CIENTÍFICA } \\
\text { BABY } \\
\end{array}$ & $\begin{array}{c}\text { ESCOVA } \\
\text { DENTAL DE } \\
\text { DEDO } \\
\text { INFA-DENT }\end{array}$ & $\begin{array}{c}\text { ESCOVA } \\
\text { DENTAL } \\
\text { PREV BABY }\end{array}$ & $\begin{array}{c}\text { TOTAL } \\
\text { DE MÃES }\end{array}$ \\
\hline SUB-GRUPO & $N(\%)$ & $N(\%)$ & N (\%) & N (\%) & N (\%) & \\
\hline Anteriores & 0 & 0 & $1(7,7)$ & $7(53,8)$ & $5(38,5)$ & 13 \\
\hline Posteriores & $1(4,3)$ & 0 & 0 & $6(26,1)$ & $16(69,6)$ & 23 \\
\hline
\end{tabular}


TABELA 14 - Comportamento dos bebês durante a realização da higiene bucal de acordo com os diferentes métodos testados.

\begin{tabular}{|c|c|c|c|c|c|c|c|c|c|c|c|c|c|c|c|}
\hline \multirow{2}{*}{$\begin{array}{l}\text { MÉTODOS } \\
\\
\\
\text { SUB- } \\
\text { GRUPO }\end{array}$} & \multirow[b]{2}{*}{$\begin{array}{l}\overline{0} \\
\frac{0}{0} \\
\overline{0} \\
\frac{0}{\pi} \\
\frac{\pi}{0} \\
0\end{array}$} & \multicolumn{2}{|c|}{ FRALDA } & \multirow[b]{2}{*}{$\begin{array}{l}\frac{1}{0} \\
\frac{0}{0} \\
\frac{0}{0} \\
\frac{0}{0} \\
\frac{0}{0}\end{array}$} & \multirow{2}{*}{$\begin{array}{l}\text { GAZE } \\
\frac{\dot{0}}{\frac{\pi}{0}} \\
\dot{0} \\
\dot{\bar{\pi}} \\
\square\end{array}$} & \multirow[b]{2}{*}{$\begin{array}{l}\frac{0}{0} \\
\frac{\pi}{0} \\
0 \\
0 \\
\text { 元 }\end{array}$} & \multicolumn{3}{|c|}{$\begin{array}{l}\text { ESCOVA DENTAL } \\
\text { CIENTÍFICA BABY }\end{array}$} & \multicolumn{3}{|c|}{$\begin{array}{c}\text { ESCOVA DENTAL DE DEDO } \\
\text { INFA-DENT }\end{array}$} & \multicolumn{3}{|c|}{$\begin{array}{c}\text { ESCOVA DENTAL PREV } \\
\text { BABY }\end{array}$} \\
\hline & & $\begin{array}{l}\frac{0}{\pi} \\
\frac{\pi}{0} \\
0 \\
\dot{\pi} \\
0\end{array}$ & $\begin{array}{l}\frac{0}{\pi} \\
\frac{\pi}{0} \\
0 \\
0 \\
0 \\
Z\end{array}$ & & & & $\begin{array}{l}\frac{1}{0} \\
\frac{0}{0} \\
\frac{0}{0} \\
\frac{0}{0} \\
0 \\
0\end{array}$ & $\begin{array}{l}\frac{\dot{\theta}}{0} \\
\frac{0}{0} \\
\dot{U} \\
\dot{\pi}\end{array}$ & $\begin{array}{l}\frac{0}{\pi} \\
\frac{\pi}{0} \\
0 \\
0 \\
\frac{10}{Z}\end{array}$ & $\begin{array}{l}\overline{0} \\
\frac{0}{0} \\
\overline{0} \\
\frac{0}{0} \\
0 \\
0\end{array}$ & $\begin{array}{l}\frac{0}{\bar{\sigma}} \\
\frac{0}{0} \\
\dot{0} \\
\dot{\sigma}\end{array}$ & $\begin{array}{l}\frac{0}{\pi} \\
\frac{\pi}{0} \\
0 \\
\text { O⿱一兀 }\end{array}$ & $\begin{array}{l}\frac{1}{0} \\
\frac{0}{0} \\
\overline{0} \\
\frac{0}{0} \\
0\end{array}$ & $\begin{array}{l}\frac{0}{\pi} \\
\frac{\pi}{0} \\
\dot{0} \\
\dot{\sigma}\end{array}$ & $\begin{array}{l}\frac{0}{\pi} \\
\frac{\pi}{0} \\
0 \\
0 \\
\frac{1 \pi}{Z}\end{array}$ \\
\hline & $\begin{array}{l}\% \\
\mathrm{~N}\end{array}$ & $\begin{array}{l}\% \\
\mathrm{~N} \\
\end{array}$ & $\begin{array}{l}\% \\
\mathrm{~N}\end{array}$ & $\begin{array}{l}\% \\
\mathrm{~N} \\
\end{array}$ & $\begin{array}{l}\% \\
\mathrm{~N} \\
\end{array}$ & $\begin{array}{l}\% \\
\mathrm{~N}\end{array}$ & $\begin{array}{l}\% \\
\mathrm{~N} \\
\end{array}$ & $\%$ & $\begin{array}{l}\% \\
\mathrm{~N}\end{array}$ & $\begin{array}{l}\% \\
\mathrm{~N} \\
\end{array}$ & $\begin{array}{l}\% \\
\mathrm{~N} \\
\end{array}$ & $\begin{array}{l}\% \\
\mathrm{~N} \\
\end{array}$ & $\begin{array}{l}\% \\
\mathrm{~N} \\
\end{array}$ & $\begin{array}{l}\% \\
\mathrm{~N} \\
\end{array}$ & $\begin{array}{l}\% \\
\mathrm{~N}\end{array}$ \\
\hline Anteriores & $\begin{array}{c}43,5 \\
10\end{array}$ & $\begin{array}{c}4,3 \\
1\end{array}$ & $\begin{array}{c}52,2 \\
12\end{array}$ & $\begin{array}{c}30,4 \\
7\end{array}$ & $\begin{array}{c}17,4 \\
4\end{array}$ & $\begin{array}{c}52,2 \\
12\end{array}$ & $\begin{array}{c}43,5 \\
10\end{array}$ & $\begin{array}{c}8,7 \\
2\end{array}$ & $\begin{array}{c}47,8 \\
11\end{array}$ & $\begin{array}{c}39,1 \\
9\end{array}$ & $\begin{array}{c}21,7 \\
5\end{array}$ & $\begin{array}{c}39,2 \\
9\end{array}$ & $\begin{array}{c}43,5 \\
10\end{array}$ & $\begin{array}{c}21,7 \\
5\end{array}$ & $\begin{array}{c}34,8 \\
8\end{array}$ \\
\hline Posteriores & $\begin{array}{c}80,0 \\
32\end{array}$ & $\begin{array}{c}12,5 \\
5\end{array}$ & $\begin{array}{c}7,5 \\
3\end{array}$ & $\begin{array}{c}82,5 \\
33\end{array}$ & $\begin{array}{c}12,5 \\
5\end{array}$ & $\begin{array}{c}5,0 \\
2\end{array}$ & $\begin{array}{c}87,5 \\
35\end{array}$ & $\begin{array}{c}5,0 \\
2\end{array}$ & $\begin{array}{c}7,5 \\
3\end{array}$ & $\begin{array}{c}90,0 \\
36\end{array}$ & $\begin{array}{c}7,5 \\
3\end{array}$ & $\begin{array}{c}2,5 \\
1\end{array}$ & $\begin{array}{c}80,0 \\
32\end{array}$ & $\begin{array}{c}15,0 \\
6\end{array}$ & $\begin{array}{c}5,0 \\
2\end{array}$ \\
\hline
\end{tabular}


O teste estatístico não mostrou diferença significativa para o comportamento dos bebês mediante os diferentes métodos de higiene bucal testados $(p<0,05)$, mas quando comparou-se o comportamento das crianças que apresentavam apenas dentes anteriores com aquelas que já possuíam dentes posteriores, houve diferença estatisticamente significante $(p<0,05)$ em todos os métodos realizados, sendo que as crianças do subgrupo posteriores se comportaram melhor do que as do subgrupo anteriores.

TABELA 15 - Evolução do comportamento dos bebês ao longo das 5 sessões.

\begin{tabular}{|c|c|c|}
\hline $\begin{array}{l}\text { EVOLUÇÃO DO } \\
\text { COMPORTAMENTO }\end{array}$ & ANTERIORES & POSTERIORES \\
\hline & $\% \quad \mathrm{~N}$ & $\%$ \\
\hline Positiva & $30,4 \quad 7$ & $87,5 \quad 35$ \\
\hline Inalterada & $69,6 \quad 16$ & 12,5 \\
\hline Negativa & - & - \\
\hline
\end{tabular}

A análise estatística mostrou diferenças significativas entre os grupos anterior e posterior $(p<0,01)$, no grupo anteriores a maioria dos bebês manteve um comportamento inalterado e no grupo posteriores a grande maioria mostrou uma melhora no comportamento. Não foi observado em ambos os grupos nenhuma evolução negativa do comportamento, ou seja, piora no comportamento dos bebês. 
6.DISCUSSÃO 


\section{DISCUSSÃO}

Seguindo a tendência mundial de prevenção presente em todos os setores, a Odontologia atual está totalmente voltada para esta filosofia e nada mais lógico do que promover o início dessa prevenção o mais precoce possível. Assim, a Odontologia em Bebês, incorpora a filosofia de atenção odontológica precoce e tem se desenvolvido muito nos últimos anos. A importância da mesma, vem sendo muito salientada na literatura $2,8,21,22,53,55,49,96$ e seus principais benefícios são: diminuição no número de crianças com cárie $^{22,49,95,96}$, estabelecimento de hábitos de higiene ${ }^{10,49}$ e alimentação $\operatorname{corretos}^{25,38,96}$, diminuição da prevalência de cárie na dentição permanente ${ }^{53}$ e identificação de problemas gerais de desenvolvimento ${ }^{55}$. Vários autores $22,25,49,95$ relatam com sucesso a experiência com este tipo de atendimento e aconselham que o primeiro contato com o cirurgião-dentista deva ocorrer durante a gestação ${ }^{2,2146}$, quando os pais recebem todas as informações importantes para assegurar uma cavidade bucal saudável para o futuro bebê, ou na época de erupção do primeiro dente e no mais tardar quando a criança completar 1 ano de idade $22,25,38$. As principais orientações dadas aos pais devem ser sobre: hábitos alimentares corretos ${ }^{8,25,53}$, aleitamento noturno ${ }^{8,22,46}$, uso do flúor ${ }^{26,53}$ e limpeza bucal $\left.\right|^{8,22,26,46,49,53}$.

Como se pode constatar nas considerações sobre a placa dentária, ela se adere firmemente à superfície dos dentes, e não sendo removida pelo fluxo 
salivar $^{23}$, exige uma ação mecânica mais intensa para ter sua formação e desenvolvimento controlados ${ }^{41,80}$.

Apesar das observações de O'LEARY ${ }^{58}$ e RIPA et al. ${ }^{67}$ relatando que os depósitos microbianos característicos da placa podem ou não estar relacionados diretamente com a cárie dentária, consideramos plenamente justificável o emprego de métodos que possibilitem remoção e controle dos diferentes tipos de placa, pois já está provado que a placa sem sofrer desorganização mecânica durante $3-4$ semanas causa cárie incipiente ${ }^{34,35,83}$ e por outro lado, sabe-se que o dente sem placa não desenvolve a lesão ${ }^{20}$. Em bebês, um dos fatores a ser avaliado quando queremos prever a probabilidade do aparecimento de cárie, é a presença de placa dentária visível na superfície vestibular dos incisivos superiores ${ }^{1,36,44,74,82}$.

Dentre os métodos para controle e remoção da placa, a escovação é o procedimento mais comumente recomendado para remoção da placa dentária $^{80}$, além de ser um procedimento muito seguro ${ }^{17}$. Estudos demonstraram que existe uma correlação negativa entre higiene bucal e cárie $^{39,78}$, mas a qualidade da limpeza proporcionada por esta higiene, muito mais do que sua freqüência, é fundamental para o sucesso na prevenção desta doença ${ }^{5}$. Além do quesito limpeza, a escovação dentária também proporciona massagem gengival, que promove melhor circulação sangüínea e adequada queratinização do epitélio ${ }^{42}$.

Mediante aos benefícios trazidos pela escovação e a introdução no mercado de consumo de novos modelos, muitos estudos foram conduzidos com intuito de pesquisar e comparar ${ }^{14,48,80,91}$ diferentes escovas dentárias. Os 
resultados de vários deles ${ }^{80,91}$, mostraram haver diferenças na efetividade de remover placa entre diferentes tipos de escovas.

Em bebês, muitos estudos correlacionaram a prática da higiene bucal com a prevenção de cárie ${ }^{19,24,30,60,62,73,79,88,98,99}$, por isso o início da higiene bucal logo após a erupção dos primeiros dentes é muito estimulado ${ }^{31,43,61,71,94,96}$. As orientações de como realizar este procedimento são variadas e dentre elas podemos destacar: limpeza com compressa de gaze 16,26,46,61,71,75,86, com fralda de tecido ${ }^{16,26,46,71,75,86,95}$, com chumaço de algodão $^{16,86}$, com dedeiras especiais ${ }^{46,86}$ e escovas dentais ${ }^{16,26,43,46,71,75,86,94,96}$.

Neste trabalho pesquisou-se a eficácia de 5 dispositivos disponíveis comercialmente, indicados para higiene bucal em bebês, e a metodologia utilizada seguiu o padrão utilizado em outros trabalhos ${ }^{12,48,52}$ do mesmo tipo. Para a avaliação da quantidade de placa optou-se por usar um índice de placa, que apesar de ser quantitativo e não indicar o tipo de placa presente ${ }^{67}$, nos permite detectar a eficácia dos procedimentos realizados com a finalidade de removê-la. O índice de placa escolhido, dentre os vários existentes ${ }^{28,29,57,64,76}$, foi o de QUIGLEY; HEIN ${ }^{65}$, que foi proposto pelos autores em um estudo da mesma natureza deste, onde foi avaliada a eficiência de limpeza de escovas dentárias. Este índice leva em consideração todos os dentes do paciente, dando atenção especial ao terço cervical dos mesmos, é simples e de fácil execução e já foi utilizado em muitos outros trabalhos do mesmo tipo ${ }^{3,4,32}$.

Com base no relato de alguns autores na literatura ${ }^{1,44,92,93}$ que consideram como parâmetro para a identificação da placa dentária no bebê aquela clinicamente visível, tentamos seguir tais orientações, mas percebemos que essa maneira não permitia uma avaliação tão precisa da quantidade de 
placa removida através da higienização, além de que para que a placa seja detectada desse modo, existe a necessidade de um tempo maior de acúmulo, tempo este que pode permitir um comprometimento da integridade do dente. Assim, para que se possa detectar a presença de placa em um estágio precoce e de uma forma mais precisa, há a necessidade do uso de uma solução corante para evidenciá-la. Várias soluções evidenciadoras são relatadas na literatura, dentre elas o verde de Malaquita que foi utilizado neste trabalho apresentando boa aceitação pelos bebês. As vantagens desta solução em relação as outras são a facilidade com que é removida dos dentes e mucosas, e o baixo custo.

A técnica de escovação adotada foi a horizontal, que segundo vários estudos $^{45,70,77}$ é a mais efetiva, principalmente em crianças pela facilidade em sua execução. A realização da higiene foi feita em um grupo pelas mães ou responsáveis e em outro pelo profissional, ou seja, por um adulto, o que é indicado amplamente na literatura ${ }^{16,31,41,45,46,77}$, principalmente em crianças com essa faixa etária. A posição adotada, com o operador atrás da cabeça da criança, também foi comprovada como muito eficaz ${ }^{18}$. Com relação ao tempo utilizado na higiene realizada pelo Odontopediatra, este foi adaptado do estudo de Santos et al. ${ }^{72}$ para crianças na faixa etária desse estudo, de acordo com observações clínicas e de conversa com as mães.

O primeiro resultado que encontramos foi o índice de placa médio observado no dia do primeiro contato com as crianças. Tal índice foi verificado em ambos os grupos ( $\mathrm{A}$ e $B$ ), sendo que um grupo já recebia atenção odontológica e outro não (Tabela 3). Este índice foi relativamente alto nos dois grupo, e não houve diferença estatisticamente significante entre eles. Estes 
dados diferem dos encontrados por MILANEZ; WALTER ${ }^{49}$, que encontraram ser menor a quantidade de crianças com placa dentre aquelas que já recebiam atenção precoce. Este fato pode ser explicado por alguns motivos, o primeiro é que as mães embora orientadas têm dificuldade em visualizar a placa dentária clinicamente, ou que não estejam motivadas o bastante para realizá-la. Outro motivo é a diferença entre os métodos de avaliar a placa nos dois trabalho, no trabalho de MILANEZ; WALTER ${ }^{49}$ a placa foi avaliada apenas como visivelmente ausente ou presente, sem o uso de solução evidenciadora e no presente estudo foi utilizada solução evidenciadora, que detecta placa aderida ao dente em estágios precoces ao da placa visível somente a olho nu.

Comparando os índices de placa médios iniciais de todas as sessões (Tabelas 4 a 8) pudemos observar que estes foram muito semelhantes nos dois grupos estudados (A e B), o que nos leva a crer que a amostra do estudo foi bastante homogênea com relação ao padrão de acúmulo de placa dentária, o que pode ser considerado um fator positivo para a investigação.

A comparação entre a porcentagem média de redução no índice de placa pelos diferentes dispositivos testados mostrou existir diferenças entre eles. No grupo onde as mães foram as responsáveis pela higiene (Tabela 9 e Fig. 14), nos bebês com apenas dentes anteriores, a maior redução foi conseguida pela escova Dental Prev Baby (19,25\%) que não teve diferença estatisticamente significante em relação à gaze (12,58\%) e à fralda $(14,85 \%)$, mas apresentou diferença estatisticamente significante em relação à escova Científica Baby $(11,76 \%)$ e à escova para uso no dedo Infa-Dent $(8,11 \%)$. Para o grupo com a presença dos dentes posteriores, novamente, a escova Dental Prev Baby se mostrou a mais eficiente $(18,39)$ e diferiu estatisticamente dos 
outros dispositivos, fralda (8,58\%), gaze (5,84\%), Científica Baby $(8,28 \%)$ e Infa-Dent (6,09\%). Com relação a superfície oclusal a escova Dental Prev Baby também mostrou-se a mais eficiente $(18,82 \%)$ com diferença estatisticamente significante das outras, fralda $(1,47 \%)$, gaze $(0,76 \%)$, Científica Baby $(7,51 \%)$ e Infa-Dent $(2,92 \%)$. O melhor desempenho da escova convencional comparado ao desempenho da fralda de tecido e da escova para uso no dedo (dedeira) Infa-Dent neste trabalho, se apresenta em concordância com o trabalho de VILLENA; BORGES; RODRIGUES ${ }^{92,93}$ que apontou redução de $29,6 \%$ para a dedeira, $47,7 \%$ para a fralda e $62,9 \%$ para uma escova convencional, mas as porcentagens médias de redução se mostraram bem diferentes para cada dispositivos, nos dois trabalhos. Este fato pode estar relacionado ao fato da avaliação de placa neste último trabalho ter sido feita sem o uso de evidenciador de placa e apenas nos dentes anteriores, onde a redução de placa é maior, devido a facilidade de acesso ${ }^{4}$. O estudo de MOURA et al. ${ }^{52}$, também apresentou resultados semelhantes aos nossos, quando comparou fralda e escova infantil, a escova se mostrou mais eficiente. Já a diferença entre a escova convencional Dental Prev Baby e a escova Científica Baby diverge dos resultados encontrados por BORGES et al. $^{12}$, que não encontraram diferenças estatisticamente significantes entre as duas escovas. A mesma explicação citada acima, quanto a avaliação apenas dos dentes anteriores, pode ser considerada, pois através do uso da escova Científica Baby, em crianças com segundos molares presentes, pudemos observar que na maioria dos casos, a cabeça da escova era impedida de alcançar estes dentes devido à presença do limitador de segurança. 
Quando comparamos os resultados dos dispositivos, entre o grupo de crianças com dentes anteriores e outro com dentes posteriores (Tabela 9 e Fig. 14), encontramos diferença estatisticamente significantes apenas para a gaze e a fralda. Isto significa que estes dois dispositivos apesar de apresentarem porcentagem média de redução numericamente menor do que da escova convencional Dental Prev Baby, para o grupo de crianças com dentes anteriores, eles têm estatisticamente a mesma eficiência da escova. Este achado mostra que a indicação por vários autores do uso da fralda $16,26,46,71,75,86,94$ e da gaze ${ }^{16,26,46,61,71,75,86}$ para limpeza de dentes anteriores é pertinente. Por outro lado, os resultados mostraram baixíssima eficiência destes métodos para limpeza das superfícies oclusais, o que mais uma vez mostra ser correta a orientação para introdução da escova dental quando da irrupção dos primeiros molares, feita por muitos autores ${ }^{16,26,43,46,71,75,86,94,96}$.

$\mathrm{Na}$ higiene realizada pelo Odontopediatra, os resultados encontrados (Tabela 10 e Fig. 15) foram praticamente os mesmos daqueles obtidos pelas mães, em relação as diferenças dos dispositivos, mas as porcentagens médias de redução de todos os dispositivos foram maiores no grupo do Odontopediatra (Tabela 11 e Fig. 16), o que já era esperado e mostra que a efetividade da higiene bucal depende da motivação da pessoa que a realiza. A única diferença foi quanto a Infa-Dent, que mostrou ser mais eficaz quando utilizada pelas mães $(7,1 \%)$ do que pelo Odontopediatra $(2,27 \%)$. Uma das possíveis explicações para isso pode ser a diferença de força exercida por ambos.

Talvez possam surgir dúvidas sobre a possibilidade da diferença dos tempos utilizados pelas mães e pelo Odontopediatra ter favorecido a diferença na quantidade de placa removida por ambos, mas de acordo com PINKHAM ${ }^{63}$ 
e com base nas observações feitas durante a realização deste experimento, acreditamos não haver correlação entre o tempo gasto durante a higienização bucal e a efetividade de limpeza da mesma.

Diante da atual situação econômica do pais, não podemos deixar de comparar os preços médios dos dispositivos testado (Tabela 2). Assim, enquanto a escova dentária para uso no dedo Infa-Dent custa $\$ 5,00$ reais, uma fralda custa $\$ 1,07$ reais, que além de apresentar menor custo, é facilmente encontrada em qualquer lar onde resida um bebê e segundo nossos resultados, apresentou uma efetividade na remoção de placa muito maior do que a dedeira Infa-Dent, podendo ser seguramente indicada para a limpeza bucal em bebês que apresentem apenas dentes anteriores. Por outro lado a escova Científica Baby, que apesar do fabricante apresentá-la como de custo reduzido, tem um preço $37 \%$ superior ao da escova Dental Prev Baby, que apresentou melhor efetividade na remoção de placa em ambos os grupos.

O tempo gasto pelas mães durante a higiene bucal nos bebês (Tabela 12), não variou conforme o método utilizado e sim com relação ao grupo do paciente, apenas para o grupo de crianças com dentes posteriores houve diferença estatisticamente significante entre a gaze e a Infa-Dent e a gaze e a Científica Baby. Este menor tempo gasto para a higiene com a gaze pode estar associado ao fato de que a mesma, quando utilizada para limpeza de superfícies oclusais, vai desfiando. O tempo médio gasto para a higiene nos bebês com apenas dentes anteriores foi de 75,4 segundos e para o grupo de bebês com dentes posteriores foi de 120,4, esta diferença é atribuída, certamente, ao número de dentes presentes nos pacientes de cada grupo. No estudo realizado por Santos et al. ${ }^{72}$ o tempo de 3 minutos se mostrou 
insuficiente e num tempo de 5 minutos, $70 \%$ de toda placa bacteriana foi removida pela escovação de crianças de 4 a 6 anos. Mas não podemos comparar esses dados, pois no presente estudo os pacientes foram de menor faixa etária, portanto com um comportamento menos colaborador, e a higiene foi realizada pelas mães e não pelas próprias crianças como no estudo já citado.

A fraca correlação encontrada entre a efetividade da remoção de placa e o tempo despendido para a mesma (Fig. 17) está em concordância com PINKHAM $^{63}$, que encontrou em seu trabalho resultados que mostraram não existir relação entre o grau de limpeza e o tempo gasto para tal. A provável explicação para tal é a variação na qualidade da limpeza realizada pelas pessoas.

Quanto à preferência das mães pelos diferentes dispositivos (Tabela 13), no grupo de bebês apenas com dentes anteriores, a maioria apontou a InfaDent $(53,8 \%)$, segundo elas devido a praticidade, a maior sensibilidade e segurança proporcionadas pelo dispositivo, em comparação com a fralda e a gaze, as mães relataram que a dedeira (Infa-Dent) protege melhor o dedo contra as mordidas durante a higiene bucal, muito comum nessa fase. No grupo de mães de pacientes com dentes posteriores, a maior preferência foi pela escova convencional $(69,9 \%)$, segundo elas a higiene se torna mais fácil nessa idade quando se usa a escova, e muitas relataram que o uso da gaze e fralda dificulta muito essa prática.

Com relação ao comportamento dos pacientes mediante a realização da higiene com os diferentes dispositivos testados, os resultados (Tabela 14) mostram não haver diferença nenhuma de comportamento relacionada aos 
métodos, discordando do trabalho de MOURA et al. ${ }^{52}$ que relatou uma melhor aceitação ao método de higienização com fralda e água filtrada. No estudo de MELO; WALTER ${ }^{47}$, também foi verificada uma preferência dos bebês, mas neste caso foi pela escova dental com dentifrício ao invés da gaze com água oxigenada, o que pode estar relacionado ao sabor desagradável desta solução.

Comparando-se os grupos de crianças com dentes anteriores e posteriores, nota-se que o grupo de bebês com dentes posteriores se comportou de uma melhor maneira, independente do método utilizado. Segundo relato de MELO; WALTER ${ }^{47}$, o mesmo foi encontrado por eles, 59,9\% dos pacientes já com dentes posteriores apresentou melhora no comportamento.

De uma maneira geral, houve uma melhora no comportamento dos pacientes ao longo das sessões (Tabela 15), fato que vem de encontro aos achados de MOURA et al. ${ }^{52}$. No grupo de crianças com dentes anteriores, $30,4 \%$ tiveram uma evolução positiva da conduta e $69,6 \%$ permaneceram inalteradas. No outro grupo, 87,5\% apresentaram melhora na conduta e apenas $12,5 \%$ apresentaram comportamento inalterado. Nenhum paciente apresentou piora do mesmo. Esta constatação evidencia a importância da criação de uma rotina, tanto de higiene bucal quanto de visitas freqüentes e regulares ao consultório odontológico.

Além da remoção de placa, devemos salientar que a introdução precoce do hábito de higiene bucal é muito importante, pois permite criar um hábito que deverá permanecer durante toda a vida do indivíduo, além de proporcionar uma massagem nas gengivas do bebê que nessa fase geralmente se encontram edemaciadas devido a irrupção dos vários dentes decíduos. Por todos esse 
benefícios, ressaltamos a necessidade de estimular os pais a praticarem em seus filhos este exercício de saúde, que é a correta higiene da cavidade bucal, além de ser esta a primeira etapa da promoção de saúde bucal. 


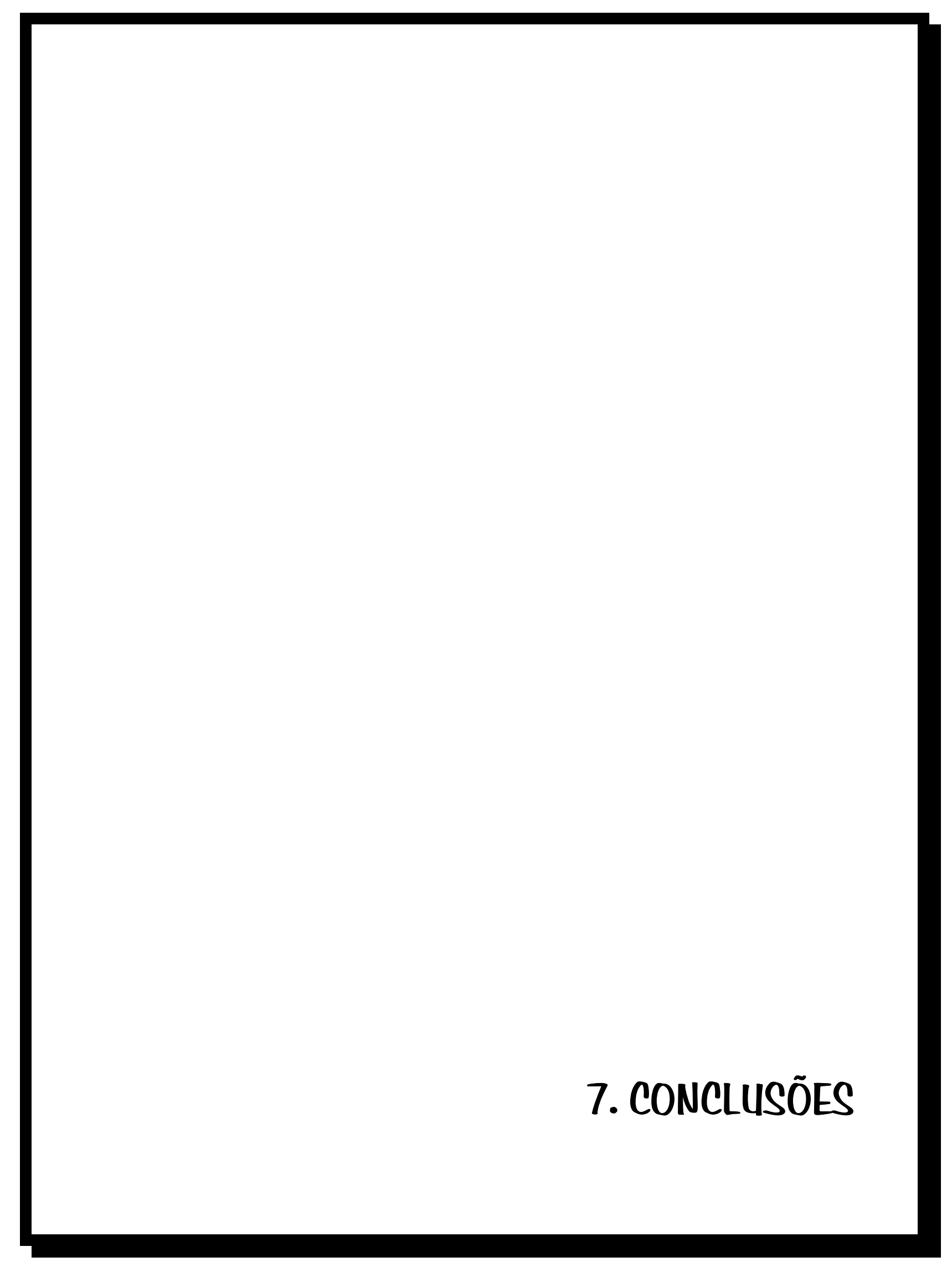




\section{CONCLUSÕES}

Pela metodologia empregada e baseado nos resultados obtidos, concluise que:

7.1 - Todos os dispositivos testados demonstraram reduzir o índice de placa dentária, mas em quantidades diferentes e nenhum deles conseguiu eliminá-la totalmente.

7.2 - A escovação realizada pelo Odontopediatra foi mais efetiva do que aquela realizada pelas mães.

7.3 - Tendo como parâmetro a redução no índice de placa, tanto para o grupo de bebês que possuem apenas dentes anteriores, quanto para o grupo que já apresenta dentes posteriores, a escova dental convencional Dental Prev Baby foi o dispositivo que mostrou melhor desempenho. O pior desempenho foi da escova dental para uso no dedo Infa-Dent, também em ambos os grupos. A fralda e a gaze se mostraram eficientes para realização da limpeza bucal em bebês com apenas dentes anteriores irrompidos.

7.4 - A conduta dos pacientes não variou conforme o tipo de dispositivo utilizado, e sim conforme a faixa etária dos mesmos.

7.5 - A maioria das mães do grupo de bebês apenas com dentes anteriores mostrou preferência pela escova dental para uso no dedo Infa-Dent, já as do grupo de bebês com dentes posteriores preferiram a escova convencional Dental Prev Baby. 
ANEXOS 
ANEXO 1

\section{FACULDADE DE ODONTOLOGIA DE BAURU COMITE DE ETICA EM PESQUISA}

Bauru, 27 de abri de 2000

llina. Sra.

Profa. Dra. Maria Aparecida de Andrade Moreira Machado

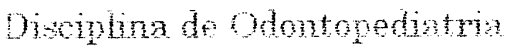

FOB USP

Sonhora Professora.

a projeto de pesquisa encaminhado a este Comite de Eutica

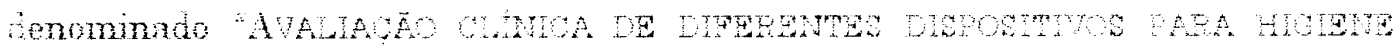

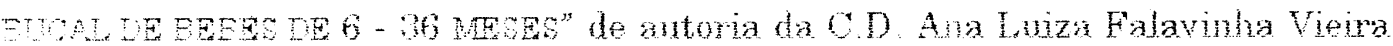
sob sua orientacano, foi reavaliado por este Comite, sob o ponto de vista ético.

Na remiao de 27 de abril, o parecer do relator foi julgado pelo Conit que o aprovou, considerando que nao existem mas questoes bticas pendentes.

Atenciosamente

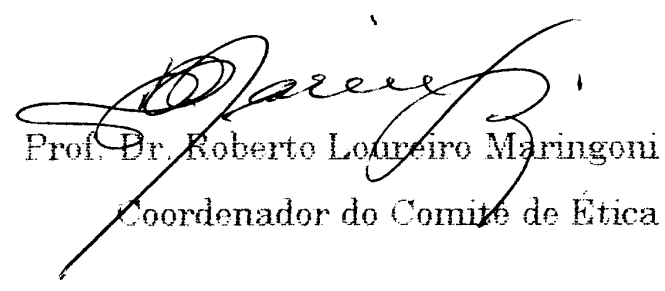


ANEXO 2

\title{
UNIVERSIDADE DE SÃO PAULO \\ FACULDADE DE ODONTOLOGIA DE BAURU \\ COMITÊ DE ÉTICA EM PESQUISA
}

TERMO DE CONSENTIMENTO LIVRE E ESCLARECIDO

\begin{abstract}
Pelo presente instrumento que atende às exigências legais, o(a) senhor(a)

portador da cédula de identidade número

responsável pela criança

após leitura minuciosa da CARTA DE INFORMAÇÃO AO PACIENTE, devidamente explicada pela profissional em seus mínimos detalhes, ciente dos serviços e procedimentos aos quais será submetido seu dependente, não restando quaisquer dúvidas a respeito do lido e explicado, firma seu CONSENTIMENTO LIVRE E ESCLARECIDO em concordância em participar da pesquisa proposta no que lhe é cabível, conforme a CARTA DE INFORMAÇÃO AO PACIENTE.

Fica claro que o paciente ou seu representante legal, podem a qualquer momento retirar seu CONSENTIMENTO LIVRE E ESCLARECIDO e deixar de participar do estudo alvo da pesquisa e ciente que todo trabalho realizado torna-se informação confidencial guardada por força do sigilo profissional (Art. 9o do Código de Ética de Odontologia).
\end{abstract}

Por estarem entendidos e conformados, assinam o presente termo.

Bauru - SP, __ de março de 2000. 
ANEXO 3

\author{
UNIVERSIDADE DE SÃO PAULO \\ FACULDADE DE ODONTOLOGIA DE BAURU \\ COMITÊ DE ÉTICA EM PESQUISA
}

\title{
CARTA DE INFORMAÇÃO AO PACIENTE
}

Este estudo tem como objetivo verificar o método mais apropriado para limpeza da boca e dentes do bebê. $O$ paciente que concordar em participar deste estudo será examinado pela cirurgiã dentista responsável e depois a própria mãe (ou responsável) realizará a limpeza dos dentes da criança e depois a dentista examinará de novo a criança para ver se o método de limpeza foi eficiente. A criança retornará a esta faculdade por 5 semanas para realização deste mesmo procedimento em cada visita. No final do estudo a mãe receberá o resultado do trabalho e informações sobre a saúde bucal de bebês. 
ANEXO 4

\section{FACULDADE DE ODONTOLOGIA DE BAURU \\ Disciplina de Odontopediatria \\ Eficiência de Dispositivos para Higiene Oral em Bebês}

Nome:

D.N.:_____ Idade: _a_

Dentes: ( ) só anteriores ( ) posteriores

Data 1․ Exame:___ / 100 Inicial Índice:

$0:$

\begin{tabular}{|c|c|c|c|c|c|c|c|c|c|c|c|c|c|c|c|c|c|c|c|c|c|c|c|}
\hline \multirow[b]{2}{*}{0} & & & & & & & & & & & & & & & & & & & & & & & \\
\hline & $\mathrm{V}$ & $L$ & 0 & $\mathrm{~V}$ & $L$ & $\mathrm{~V}$ & $L$ & $\mathrm{~V}$ & $\mathrm{~L}$ & & $L$ & V & $L$ & $\mathrm{~V}$ & $L$ & $\mathrm{~V}$ & $L$ & 0 & $\mathrm{v}$ & 1 & 0 & $\mathrm{v}$ & \\
\hline & 55 & & & 54 & & 5 & & & & & & & & 6 & & 6 & & & 64 & & & 64 & \\
\hline & 85 & & & 84 & & & & & & & & & & & & & & & 74 & & & 75 & \\
\hline 0 & $\mathrm{~V}$ & $L$ & 0 & $\mathrm{~V}$ & $L$ & $V$ & $L$ & V & $L$ & $V$ & $L$ & V & $L$ & V & $L$ & V & $L$ & 0 & V & $L$ & 0 & V & $L$ \\
\hline & & & & & & & & & & & & & & & & & & & & & & & \\
\hline
\end{tabular}

Opinião da mãe:

Comportamento do Bebê:

Tempo:

Data 2० Exame:____/ 100 Inicial Índice:

$0:$

\begin{tabular}{|c|c|c|c|c|c|c|c|c|c|c|c|c|c|c|c|c|c|c|c|c|c|c|c|}
\hline & & & & & & & & & & & & \multirow{2}{*}{\multicolumn{2}{|c|}{\begin{tabular}{l|l}
$V$ & $L$
\end{tabular}}} & \multicolumn{2}{|r|}{ 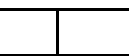 } & \multicolumn{2}{|c|}{ 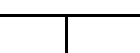 } & & \multicolumn{4}{|c|}{ 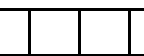 } \\
\hline 0 & V & $L$ & 0 & V & $L$ & V & $L$ & V & $L$ & V & $L$ & & & V & $L$ & V & $L$ & 0 & V & $L$ & 0 & V & L \\
\hline & 55 & & & 54 & & & & & & & & & & & & & & & 64 & & & 64 & \\
\hline & 85 & & & 84 & & & 3 & & & & & & & & & & & & 74 & & & 75 & \\
\hline 0 & $\mathrm{~V}$ & $L$ & 0 & $\mathrm{~V}$ & $L$ & $\mathrm{~V}$ & $\mathrm{~L}$ & $\mathrm{~V}$ & $L$ & $\mathrm{~V}$ & $L$ & $\mathrm{~V}$ & L & $\mathrm{V}$ & $\mathrm{L}$ & $\mathrm{V}$ & L & 0 & $\mathrm{v}$ & $L$ & 0 & $\mathrm{~V}$ & \\
\hline
\end{tabular}

Método:

Indice:

O:

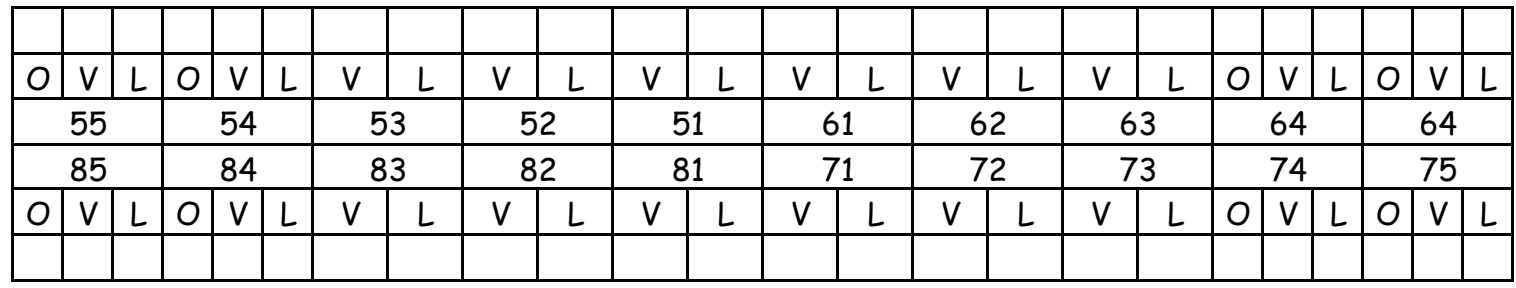

Opinião da mãe:

Bebê:

Tempo: 
Data 3 Exame:_____ / 100 Inicial Índice:

$0:$

\begin{tabular}{|c|c|c|c|c|c|c|c|c|c|c|c|c|c|c|c|c|c|c|c|c|c|c|c|}
\hline & \\
\hline 0 & $\mathrm{~V}$ & $L$ & 0 & $\mathrm{~V}$ & $L$ & V & $L$ & V & $L$ & V & $L$ & V & $L$ & V & $L$ & $V$ & $L$ & 0 & $\mathrm{~V}$ & $L$ & 0 & $\mathrm{~V}$ & $L$ \\
\hline \multicolumn{3}{|c|}{55} & \multicolumn{3}{|c|}{54} & \multicolumn{2}{|c|}{53} & \multicolumn{2}{|c|}{52} & \multicolumn{2}{|c|}{51} & \multicolumn{2}{|c|}{61} & \multicolumn{2}{|c|}{62} & \multicolumn{2}{|c|}{63} & \multicolumn{3}{|c|}{64} & \multicolumn{3}{|c|}{64} \\
\hline \multicolumn{3}{|c|}{85} & \multicolumn{3}{|c|}{84} & \multicolumn{2}{|c|}{83} & \multicolumn{2}{|c|}{82} & \multicolumn{2}{|c|}{81} & \multicolumn{2}{|c|}{71} & \multicolumn{2}{|c|}{72} & \multicolumn{2}{|c|}{73} & \multicolumn{3}{|c|}{74} & \multicolumn{3}{|c|}{75} \\
\hline 0 & $\mathrm{~V}$ & $L$ & 0 & $\mathrm{~V}$ & $L$ & $\mathrm{~V}$ & $L$ & $\mathrm{~V}$ & $L$ & $\mathrm{~V}$ & L & $\mathrm{V}$ & $L$ & V & $L$ & $\mathrm{~V}$ & $L$ & 0 & $\mathrm{~V}$ & $L$ & 0 & $\mathrm{~V}$ & \\
\hline & & & & & & & & & & & & & & & & & & & & & & & \\
\hline
\end{tabular}

Método:

Índice:

O:

\begin{tabular}{|c|c|c|c|c|c|c|c|c|c|c|c|c|c|c|c|c|c|c|c|c|c|c|c|}
\hline & & & & & & & & & & & & & & & & & & & & & & \\
\hline 0 & $\mathrm{~V}$ & $L$ & 0 & $\mathrm{~V}$ & $L$ & $\mathrm{~V}$ & $L$ & $\mathrm{~V}$ & $L$ & $\mathrm{~V}$ & $L$ & $\mathrm{~V}$ & $L$ & $\mathrm{~V}$ & $L$ & $\mathrm{~V}$ & $L$ & 0 & $\mathrm{~V}$ & $L$ & 0 & $\mathrm{~V}$ & $L$ \\
\hline \multicolumn{3}{|c|}{55} & \multicolumn{3}{|c|}{54} & \multicolumn{2}{|c|}{53} & \multicolumn{2}{|c|}{52} & \multicolumn{2}{|c|}{51} & \multicolumn{2}{|c|}{61} & \multicolumn{2}{|c|}{62} & \multicolumn{2}{|c|}{63} & \multicolumn{3}{|c|}{64} & \multicolumn{3}{|c|}{64} \\
\hline \multicolumn{3}{|c|}{85} & \multicolumn{3}{|c|}{84} & \multicolumn{2}{|c|}{83} & \multicolumn{2}{|c|}{82} & \multicolumn{2}{|c|}{81} & \multicolumn{2}{|c|}{71} & \multicolumn{2}{|c|}{72} & \multicolumn{2}{|c|}{73} & \multicolumn{3}{|c|}{74} & \multicolumn{3}{|c|}{75} \\
\hline 0 & $\mathrm{~V}$ & $L$ & 0 & $\mathrm{~V}$ & $L$ & $\mathrm{~V}$ & $L$ & $\mathrm{~V}$ & $L$ & $\mathrm{~V}$ & $L$ & $\mathrm{~V}$ & $L$ & $\mathrm{~V}$ & $L$ & $\mathrm{~V}$ & $L$ & 0 & $\mathrm{~V}$ & $L$ & 0 & $\mathrm{~V}$ & $L$ \\
\hline & & & & & & & & & & & & & & & & & & & & & & & \\
\hline
\end{tabular}

Opinião da mãe:

Bebê:

Tempo:

Data 4 Exame:____/ $/ 00$ Inicial Índice:

$0:$

\begin{tabular}{|c|c|c|c|c|c|c|c|c|c|c|c|c|c|c|c|c|c|c|c|c|c|c|c|}
\hline & & & & & & & & & & & & & & & & & & & & & & & \\
\hline \multirow{3}{*}{0} & \multirow{2}{*}{\multicolumn{2}{|c|}{$\frac{V}{55}$}} & 0 & V & $L$ & V & $L$ & V & $L$ & V & $L$ & V & $L$ & V & $L$ & V & $L$ & 0 & V & $L$ & 0 & $\mathrm{~V}$ & $L$ \\
\hline & & & \multicolumn{3}{|c|}{54} & \multicolumn{2}{|c|}{53} & \multicolumn{2}{|c|}{52} & \multicolumn{2}{|c|}{51} & \multicolumn{2}{|c|}{61} & \multicolumn{2}{|c|}{62} & \multicolumn{2}{|c|}{63} & \multicolumn{3}{|c|}{64} & \multicolumn{3}{|c|}{64} \\
\hline & \multicolumn{2}{|l|}{85} & \multicolumn{3}{|c|}{84} & \multicolumn{2}{|c|}{83} & \multicolumn{2}{|c|}{82} & \multicolumn{2}{|c|}{81} & \multicolumn{2}{|c|}{71} & \multicolumn{2}{|c|}{72} & \multicolumn{2}{|c|}{73} & \multicolumn{3}{|c|}{74} & \multicolumn{3}{|c|}{75} \\
\hline 0 & V & $L$ & 0 & V & $L$ & $\mathrm{~V}$ & $L$ & V & $L$ & V & $L$ & V & $L$ & V & $L$ & V & $L$ & 0 & $\mathrm{~V}$ & $L$ & 0 & $\mathrm{~V}$ & 1 \\
\hline & & & & & & & & & & & & & & & & & & & & & & & \\
\hline
\end{tabular}

Método:

Índice:

O:

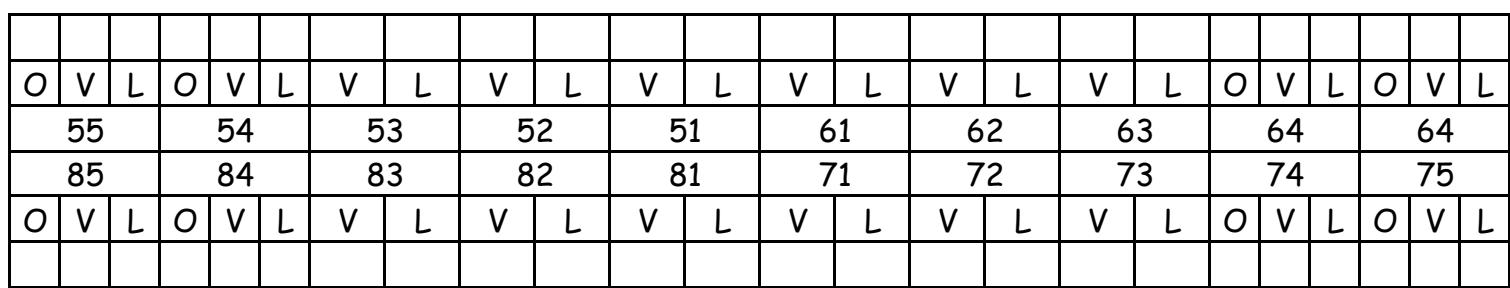

Opinião da mãe:

Bebê:

Tempo:

Bebê: 
Data 5o Exame:____ / 100 Inicial Índice:

$0:$

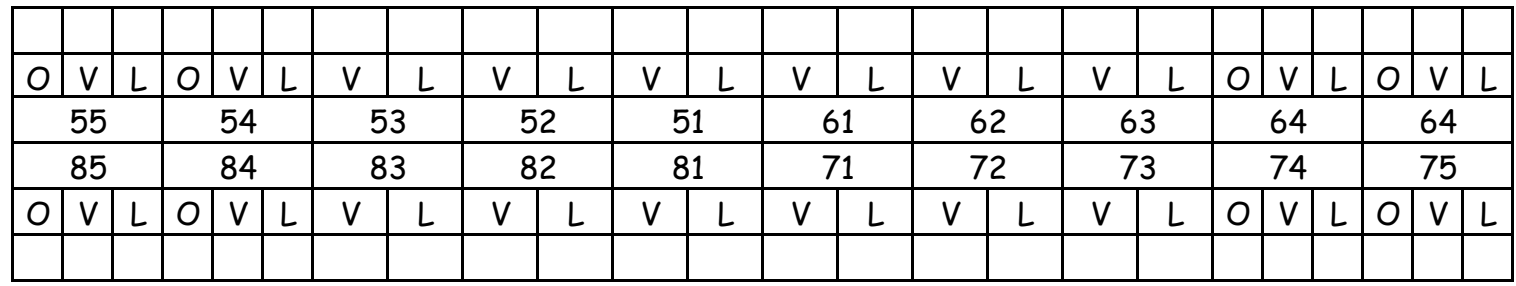

Método:

Indice:

O:

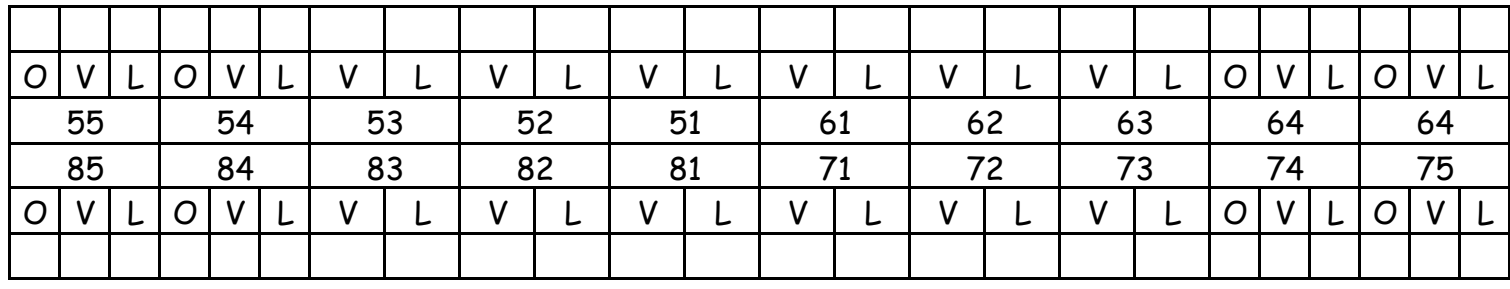

Opinião da mãe:

Bebê:

Tempo:

Data 60 Exame:____ 100 Inicial Índice:

$0:$

\begin{tabular}{|c|c|c|c|c|c|c|c|c|c|c|c|c|c|c|c|c|c|c|c|c|c|c|c|}
\hline & & & & & & & & & & & & & & & & & & \multirow{2}{*}{\multicolumn{3}{|c|}{\begin{tabular}{l|l} 
&
\end{tabular}}} & \multirow{2}{*}{\multicolumn{3}{|c|}{+}} \\
\hline & & & & & & & & & & \multirow[b]{2}{*}{ V } & \multirow[b]{2}{*}{$L$} & \multirow[b]{2}{*}{ V } & \multirow{2}{*}{$L$} & \multirow{2}{*}{$\mathrm{V}$} & 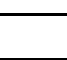 & \multicolumn{2}{|r|}{ 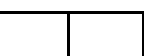 } & & & & & & \\
\hline 0 & $\mathrm{~V}$ & $L$ & 0 & V & $L$ & V & $L$ & V & $L$ & & & & & & $L$ & V & $L$ & 0 & $\mathrm{~V}$ & $L$ & 0 & V & \\
\hline & 55 & & & 54 & & & & & & & & & & & & & & & 64 & & & 64 & \\
\hline & 85 & & & 84 & & & & & & & & & & & & & & & 74 & & & 75 & \\
\hline 0 & V & $L$ & 0 & $V$ & $L$ & $\mathrm{~V}$ & $L$ & $\mathrm{~V}$ & $L$ & $\mathrm{~V}$ & $L$ & $V$ & $L$ & $V$ & $L$ & $\mathrm{~V}$ & $L$ & 0 & V & $L$ & 0 & $\mathrm{~V}$ & $L$ \\
\hline
\end{tabular}

Método:

Índice:

O:

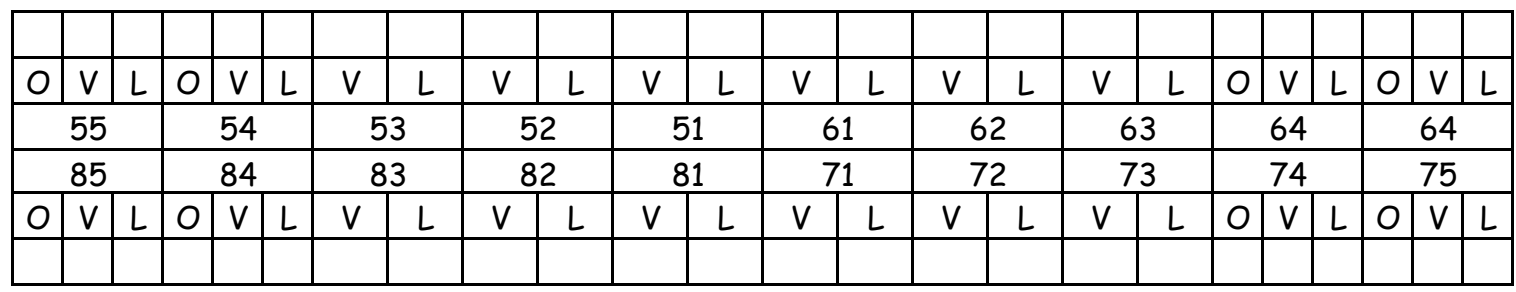

Opinião da mãe:

Bebê:

Tempo:

Qual foi o melhor método para a mãe?

( )Dedeira ( )Gaze ( )Fralda ( )Científica Baby ( ) Escova 
REFERÊNCIAS BIBLIOGRÁFICAS 


\section{REFERÊNCIAS BIBLIOGRÁFICAS}

1. ALALUUSUA, S.; MALMIVIRTA, R. Early plaque accumulation - a sign for caries risk in young children. Community Dent. oral Epidem., v.22, n.5, p.273-6, 1994.

2. AMERICAN ACADEMY OF PEDIATRIC DENTISTRY. Reference manual: oral health policies. Pediat. Dent., v.21, n.5, p.77, 1999/2000. Special Issue.

3. BASTIAAN, R.J. The cleaning efficiency of different toothbrushes in children. J. clin. Periodont., v.13, n.9, p.837-40, Oct. 1986.

4. BAY, I; KARDEL, K.M.; SKOUGAARD, M.R. Quantitative evaluation of the plaque-removing ability of different types of toothbrushes. J. Periodontol., v.38, n.6, p.526-33, Nov./Dec. 1967.

5. BELLINI, H.T.; ARNEBERG, P.; VON DER FEHR, F.R. Oral hygiene and caries - a review. Acta odont. scand., v.39, n.5, p.257-65, 1981.

6. BIGNELLI, P. Odontologia preventiva para bebês: novo instrumento de higiene bucal - a escova científica baby. J. Bras. Odontoped. e Odonto. bebe, v.1, n.2, s.p., abr./jun. 1998.

7. BINNEY, A.; ADDY, M.; NEWCOMBE, R.G. The plaque removal effects of single rinsings and brushings. J. Periodontol., v.64, n.3, p.181-5, Mar. 1993.

\footnotetext{
* Normas recomendadas para uso no âmbito da Universidade de São Paulo, com base no documento "Referências bibliográficas: exemplos" emanado do Conselho Superior do Sistema Integrado de Bibliotecas da USP, em reunião de 20 de setembro de 1990.
} 
8. BLEN, M.; NARENDRAN, S.; JONES, K. Dental caries in children under age three attending a university clinic. Pediat. Dent., v.21, n.4, p.261-4, July/Aug. 1999.

9. BLINKHORN, A.S. Dental health education: what lessons have we ignored? Br Dent J, v.184, n.2, p. 58-9, Jan. 1998.

10. BLINKHORN, A.S. Factors influencing the transmission of the toothbrushing routine by mothers to their pre-school children. J. Dent., v.8, n.4, p.307-11, 1980.

11. BONECKER, M.J.S.; GUEDES-PINTO, A.C.; WALTER, L.R.F. Prevalência, distribuição e grau de afecção da cárie dentária em crianças de 0 à 36 meses de idade. Rev. Ass. paul. cir. Dent., v.51, n.6, p.535-40, nov./dez. 1997.

12. BORGES, D.G. et al. Comparison of the plaque removal effectiveness of conventional and alternative toothbrushes in babies. J. dent. Res., v.78, p.413, 1999. Special Issue. /Apresentado à International Association of Dental Research 77 General Session, Vancouver, 1999 - Resumo/

13. BUISCHI, Y. P.; AXELSSON, P. Controle mecânico da placa dental realizado pelo paciente. In: KRIGER, L. Promoção de saúde bucal. Artes Médicas, São Paulo, 1997. Cap.6, p.113-27.

14. CLAYDON, N.; ADDY, M. Comparative single-use plaque removal by toothbrushes of different designs. J. clin. Periodont., v.23, n.12, p.1112-6, Dec. 1996. 
15. CURTIS, G.H. et al. A clinical study of the effectiveness of the roll and charters' method of brushing teeth. J. Periodontol., v.28, n.4, p.27780, Oct. 1957.

16. DEAN, J.A.; HUGHES, C.V. Métodos mecânicos e quimioterapêuticos caseiros de higiene oral. In: McDONALD, R.E.; AVERY, D.R. Odontopediatria. 6.ed. Rio de Janeiro, Guanabara Koogan, 1995. Cap.11, p.176-94.

17. DUARTE, C.A.; LOTUFO, R.F.M. Etiopatogeneia da doença periodontal e cárie - importância da placa bacteriana. In Prevenção na clínica odontológica: promoção de saúde. São Paulo, Artes Médicas, 1997. Cap 4, p.30-50.

18. EDUARDO, M.A.P.; LONG, S.M.; CHELOTTI, A. Escovação em crianças durante a primeira infância: avaliação das posições adotadas por adultos. Rev. Ass. paul. cir. Dent., v.53, n.4, p.316-9, jul./ago. 1999.

19. ERONAT, N.; EDEN, E. A comparative study of some influencing factors of rampant or nursing caries in preschool children. J. clin. Pediat. Dent., v.16, n.4, p.257-9, 1992.

20. FEJERSKOV, O. Concepts of dental caries and their consequences for understanding the disease. Community Dent. oral Epidemiol., v.25, n.1, p.5-12, Feb. 1997.

21. FRITSHER, A.M.G.; ARAUJO, D.F.; FIGUEIREDO, M.C. Avaliação comparativa dos índices de cárie, placa visível e sangramento gengival de 50 pares mãe-filho. J. Bras. Odontoped. e Odonto. bebe, v.1, n.4, p.34-42, 1998. 
22. GARBOZA, C.S.; WALTER, L.R.F. Estudo da prevalência de cárie numa população de 0 a 5 anos atendida precocemente pela bebê-clínica da Universidade Estadual de Londrina. Semina, v.18, p.51-4, fev. 1997. Edição especial.

23. GIBBONS, R.J.; VAN ROUTE, J.V. On the formation on dental plaques. J. Periodontol., v.44, n.6, p.347-57, June 1973.

24. GIBSON, S.; WILLIAMS, S. Dental caries in pre-school children: associations with social class, toothbrushing habit and consumption of sugars and sugar-containing foods. Caries Res., v.33, n.2, p.10313, 1999.

25. GOEPFERED, S.J. An infant oral health program: the first 18 months. Pediat. Dent., v.9, n.1, p. 8-12, Mar. 1987.

26. GOEPFERED, S.J. Infant oral health: a protocol. J. Dent. Child., v.53, n.4, p.261-6, July/Aug. 1986.

27. GORDON, Y.; REDDY, J. Prevalence of dental caries, patterns of sugar consumption and oral hygiene practices in infancy in S. Africa. Community Dent. oral Epidemiol., v.13, n.6, p.310-4, 1985.

28. GREENE, J.C.; VERMILLION, J.R. The oral hygiene index: a method for classifying oral hygiene status. J. Am. dent. Assoc., v.61, p. 172-9, Aug.1960.

29. GREENE, J.C.; VERMILLION, J.R. The simplified oral hygiene index. J. Am. dent. Assoc., v. 68, p. 7-13, 1964.

30. GRINDEFJORD, M. et al. Prediction of dental caries development in 1year-old children. Caries Res., v.29, n.5, p.343-8, 1995. 
31. GUEDES-PINTO, A.C.; CRUZ, R.A.; PARREIRA, M.L.J. Escovação dental - aspectos gerais e técnicas aplicadas a crianças. Rev. Ass. paul. cirurg. Dent., v.26, n.5, p.272-7, set./out. 1972.

32. HALL, A.W.; CONROY, C.W. Comparison of automatic and hand toothbrushes: toothbrushing effectiveness for preschool children. J. Dent. Child, v.38, n.5, p. 309-13, Sep./Oct. 1971.

33. HERRMANN, H.J.; ROBERTS, M.W. Preventive dental care: role of the pediatrician. Pediatrics, v. 80, n.1, p.107-10, July 1987.

34. HOLMEN, L. et al. A scanning electron microscopic study of progressive stages of enamel caries in vivo. Caries Res., v.19, n.4, p.355-67, 1985.

35. HOLMEN, L.; THYLSTRUP, A.; ARTUN,J. Surface changes during the arrest of active enamel carious lesions in vivo. A scanning electron microscope study. Acta odont. scand., v.45, n.6, p.383-90, Dec. 1987.

36. ISMAIL, A.I. Prevention of early childhood caries. Community Dent. oral Epidemiol., v. 26, p.49-61, 1998. Supplement 1.

37. JANNIS, J. Eficiência comparada de duas técnicas de escovação na remoção da placa dentária. Florianópolis, 1974. 165 p. Tese (LivreDocência) - Faculdade de Odontologia, Universidade Federal de Santa Catarina.

38. KAMP, A.A. Well-baby dental examinations: a survey of preschool children's oral health. Pediat. Dent., v.13, n.2, p.86-9, Mar./Apr. 1991. 
39. KOLMAKOW, S.; NYYSSONEN, V.; HONKALA, E. Determining the caries at-risk child: part I - focal demineralization in children's teeth. J. Pedod., v.9, n.1, p.58-66, Fall 1984.

40. KOROLUK, L.D.; HOOVER, J.N.; KOMIYAMA, K. Factors related to plaque distribution in a group of Canadian preschool children. Int. J. Paed. Dent., v.4, n.3, p.167-72, Sept. 1994.

41. KRAMER, P.F.; FELDENS, C.A.; ROMANO, A.R. Tratamento não invasivo. In:_. Promoção de saúde bucal em Odontopediatria. Artes Médicas, São Paulo, 1997. Cap.6, p.89-112. 42. KWON, H.S.; GUEDES-PINTO, A.C. Higiene buco-dental em crianças. In: GUEDES-PINTO, A.C. Odontopediatria. 5.ed., Ed. Santos, São Paulo, 1995. Cap.28, p.579-603.

43. MARTINS, A.L.C.F.; TESSLER, A.P.C.V.; CORRÊA, M.S.N.P. Controle mecânico e químico da placa bacteriana. In: CORREA, M.S.N.P. Odontopediatria na primeira infância. São Paulo, Santos, 1998. Cap.12, p.271-8.

44. MATTOS-GRANER, R.O. et al. Association between caries prevalence and clinical, microbiological and dietary variables in 1.0 to 2.5 -yearold Brazilian children. Caries Res., v.32, n.5, p. 319-23, 1998.

45. McCLURE, D.B.A comparison of toothbrushing techniques for preschool child. J. Dent. Child., v.33, n.3, p.205-10, May 1966.

46. MEDEIROS, U.V. Atenção odontológica para bebês. Rev. paul. Odont., v. , n.6, p.18-27, nov./dez. 1993. 
47. MELO, M.M.; WALTER, L.R.F. Mudança do comportamento infantil diante do hábito de escovar os dentes. Semina, v.18, p.63-8, fev. 1997. Edição especial.

48. MESTRINHO, H.D.; CARVALHO, J.C.; FIGUEIREDO, C.S. Desempenho clínico das escovas infantis produzidas no Brasil. Rev. gaúcha Odont., v.42, n.5, p.254-8, set./out. 1994.

49. MILANEZ, F.G.; WALTER, L.R.F. Estudo comparativo entre a presença de placa visível e cárie dentária em crianças de 18 a 40 meses de 2 populações distintas. Semina, v.18, p.47-50, fev. 1997. Edição especial.

50. MINAH, G.E.; LOESCHE, W.J. Sucrose metabolism by prominent members of the flora isolated from cariogenic and non-cariogenic dental plaques. Infect. Immun., v.17, n.1, p.55-61, July 1977.

51. MORITA, M.C.; WALTER, L.R.F.; GUILLAIN, M. Prévalence de la cárie dentaire chez des enfants Brésiliens de 0 à 36 mois. J. Odont. Stomato. Pédiatr., v.3, n.1, p.19-28, Mar.1993.

52. MOURA, L.F.A.D.; REBELO, M.C.C.B.L.; MOURA, M.D; ARÊA LEÃO, V. L. Avaliação da eficácia de métodos de higiene bucal em bebês. J. Bras. Odontoped. e Odonto. bebe, v.3, n.12, p.141-6, abr./mai. 2000.

53. NAVIA, J.M. Caries prevention in infants and young children: which etiologic factors should we address? J. Public Health Dent., v.54, n.4, p.195-6, 1994.

54. NEWBRUN, E. Conceitos atuais da etiologia da cárie. In:

Cariologia. 2 ed. São Paulo, Ed. Santos, 1988. Cap.2, p.17-49. 
55. NOWAK, A.J.; CASAMASSIMO, P.S. Using anticipatory guindace to provide early dental intervention. J. Amer. dent. Ass., v.126, n.8, p.1156-63, Aug. 1995.

56. O'LEARY, T.J. Oral hygiene agents and procedures. J. Periodont., v.41, n.11, p.625-9, Nov. 1970.

57. OGASAWARA, T.; WATANABE, T.; KASAHARA, H. Readiness for toothbrushing of young children. J. Dent. Child, v. 59, n.5, p.353-9, Sep./Oct. 1992.

58. O'LEARY, T.J.; DRAKE, R.B.; NAYLOR, J.E. The plaque control record. J. Periodont., v.43, n.1, p.38, Jan. 1972.

59. OPPENHEIM, M.N. Early infancy oral health care. N. Y. St. dent. J., v.62, n.2, p.22-4, 1996.

60. PAUNIO, P. et al. dental health habits of 3-year-old Finnish children.

Community Dent. oral Epidemiol., v.21, n.1, p.4-7, 1993.

61. PEREIRA, D.B. Educação dentária da criança. Rio de Janeiro, 1929, 79p. apud GARBOZA, C.S.; WALTER, L.R.F. ${ }^{22}$

62. PERSSON, L. et al. Infant feeding and dental caries - a longitudinal study of Swedish children. Swed. Dent. J., v.9, n.5, p.201-6, 1985.

63. PINKHAM, J.R. Oral hygiene in children: relationship to age and brushing time. J. Prev. Dent., v.2, n.2, p.28-31, Mar./Apr.1975.

64. PODSHADLEY, A.G.; HADLEY, J.V. A method for evaluating oral hygiene performance. Publ. Health Rep., v.83, n.3, p.259-64, Mar. 1968. 
65. QUIGLEY, G.A.; HEIN, J.W. Comparative cleansing efficiency of manual and power brushing. J. Amer. dent. Ass., v.65, n.1, p.27-9, July 1962.

66. REISINE, S.; LITT, M.; TIANANOFF, N. A biopsychosocial model to predict caries in preschool children. Pediat. Dent., v.16, n.6, p.413-8, Nov./Dec. 1994.

67. RIPA, L.W. et al. The relationship between oral higyene and dental health, an epidemiological survey. N. Y. St. dent. J., v.43, p.530-5, Nov. 1977.

68. RIPA, L.W. Nursing caries: a comprehensive review. Pediat. Dent., v.10, n.4, p.268-82, 1988.

69. ROETERS, J. et al. Dental caries and its determinants in 2-to-5-year-old children. J. Dent. Child, v.62, n.6, p.401-8, Nov./Dec. 1995.

70. SANGNES, G.; ZACHRISSON, B.; GJERMO, P. Effectiveness of vertical and horizontal brushing techniques in plaque removal. J. Dent. Child., v. 39, n.2, p.14-7, Apr. 1972.

71. SANTOS, E.M.; GUEDES-PINTO, A.C. Higiene bucodental em Odontopediatria. In: GUEDES-PINTO, A.C. Odontopediatria clínica. São Paulo, Artes Médicas, EAP-APCD, 1998. Cap.5, p.6072.

72. SANTOS, V.I.M. et al. Estudo clínico experimental relativo à duração e eficiência da escovação dentária em crianças de 4 a 6 anos de idade. Rev. Fac. Odont. USP, v.4, n.4, p.318-22, out./dez. 1990. 
73. SCHRÖDER, U; GRANATH, L. Dietary habits and oral hygiene as predictors of caries in 3-years-old children. Community Dent. oral Epidemiol., v.11, n.5, p.306-11, 1983.

74. SEOW, W.K. et al. Prevalence of caries in urban Australian aborigines aged 1-3,5 years. Pediat. Dent., v.21, n.2, p.91-6, Mar./Apr. 1999.

75. SERINO,R.J.; GOLD, S.B. Infant and early childhood oral health care. N. Y. St. Dent. J., v.63, n.2, p.34-5, 1997.

76. SILNESS, J.; LÖE, H. Periodontal disease in pregnancy - part II correlation between oral hygiene and periodontal condition. Acta odont. scand., v.22, p.121-35, 1964.

77. STARKEY, P. Instructions to parents for brushing the child's teeth. J. Dent. Child., v.28, n.1, p.42-7, 1961.

78. STECKSEN-BLICKS, C.; GUSTAFSSON, L. Impact of oral hygiene and use of fluorides on caries increment in children during one year. Community Dent. oral Epidemiol., v.14, n.4, p.185-9, 1986.

79. STECKSEN-BLICKS, C.; HOLM, A.K. Between-meal eating, toothbrushing frequency and dental caries in 4-year-old children in the north of Sweden. Int. J. Paed. Dent., v.5, n.2, p.67-72, June 1995.

80. SUOMI, J.D.A et al. A comparison of the plaque-removing ability of a standard and an unconventional toothbrush. J. Dent. Child., v.39, n.6, p.35-9, Nov./Dec. 1972.

81. THELAIDE, E.; THELAIDE, J. Role of plaque in the etiology of periodontal disease and caries. Oral Sci. Rev., v.9, p.23-63, 1976. 
82. THOMAS, H.F. First dental visit, first birthday: a rationale and protocol for infant oral health care. Tex. Dent. J., v.114, n.1, p.15-9, 1997.

83. THYLSTRUP, A.; BRUNN, C.; HOLMEN, L. In vivo caries models mechanisms for caries initiation and arrestment. Advanc. dent. Res., v.8, n.2, p.144-57, July 1994.

84. THYLSTRUP, A; FEJERSKOV, O. Diferentes conceitos da cárie dentária e suas implicações. In: Cariologia Clínica. 2.ed. São

Paulo, Ed. Santos, 1995. Cap.9, p.209-17.

85. TINANOFF, N. Introduction to the early childhood caries conference: initial description and current understanding. Community Dent. oral Epidemiol., v. 26, p.5-7, 1998. Supplement 1.

86. TOLLARA, M.; SALIM, D; CORRÊA, M.S.N.P. Métodos de higiene bucal e as diferentes posições de escovação na primeira infância. In: ENCONTRO NACIONAL DE ODONTOLOGIA PARA BEBÊS, 2., Londrina, 1998. Anais. Londrina, s.ed., 1998. p.37.

87. TOVO, L.C. Placa dental e índice de higiene oral. Rev Fac. Odont. P.A., v.10/11, p. $77-81,1968 / 69$.

88. TSUBOUCHI, J. et al. Baby bottle tooth decay: a study of baby bottle tooth decay and risk factors for 18-month old infants in rural Japan. J. Dent. Child., v.61, n.4, p.293-8, July/Aug. 1994.

89. UDIN, R.D. Newer approaches to preventing dental caries in children. J. Calif. Dent. Ass., v.27, n.11, Nov. 1999.

90. VILLENA, R.S. et al. Oral hygiene practice in children aged 1 to 7 in São Paulo. J. dent. Res., v.76, n.5, p.969, May 1997. /Apresentado à 
Brazilian Division 13 Annual Meeting, Águas de São Pedro, 1996 Resumo/

91. VILLENA, R.S. et al. Remoção de placa bacteriana com escovas de cabeça tripla e convencional em crianças de 3 a 5 anos: estudo comparativo. Rev. bras. Odont, v.53, n.4, p.20-2, 1996.

92. VILLENA, R.S.; BORGES, D.G.; RODRIGUES, C.R.D.M. Avaliação da efetividade na remoção de placa utilizando métodos convencionais e alternativos em bebês. In: REUNIÃO ANUAL DA SOCIEDADE BRASILEIRA DE PESQUISA ODONTOLÓGICA, 14., Águas de São Pedro, 1997. Anais. São Paulo, SBPqO, 1997. p.166.

93. VILLENA, R.S.; BORGES, D.G.; RODRIGUES, C.R.D.M. Evaluation of the efectiveness of plaque removal using conventional and alternative methods in babies. J. dent. Res., v.77, n.5, p.1183, May 1998. /Apresentado à Brazilian Division 14 Annual Session, Águas de São Pedro, 1997 - Resumo/

94. WALTER, L.R.F.; FERELLE, A.; ISSAO, M. Educação odontológica: necessidades educativas. In: Odontologia para o bebê: Odontopediatria do nascimento aos 3 anos. São Paulo, Artes Médicas, 1996. Cap.5, p.74-91.

95. WALTER, L.R.F.; NAKAMA, L. Pacientes de alto índice de cárie $x$ pacientes de alto risco. Qual a conduta? Atualização na cínica odontológica. Artes Médicas, São Paulo, 1992. Cap.18, p.251-7.

96. WANDERA, A. Anticipatory guidance in infant oral health. J. Mich. Dent. Assoc., v.80, n.9, p. 28; 55-9, Nov./Dec. 1998. 
97. WEINSTEIN, P. Public health issues in early childhood caries. Community Dent. oral Epidemiol., v.26, p.84-90, 1998. Supplement 1 .

98. WENDT, L.K. et al. Oral hygiene in relation to caries development and immigrant status in infants and toddlers. Scand. J. Dent. Res., v.102, n.5, p.269-73, 1994.

99. WINTER, G.B. Prediction of high caries risk - diet, hygiene and medication. Int. dent. J., v.38, n.4, p.227-30, 1988. 
ABSTRACT 


\section{ABSTRACT \\ Clinical evaluation of the effectiveness of dental plaque removal by different devices used for oral hygiene in babies}

This study evaluated the plaque removal effectiveness by five different devices indicated for oral hygiene in babies: diaper, gauze, single injection toothbrush "Cienífica Baby", finger brush "Infa-Dent" and a conventional toothbrush "Dental Prev Baby". Each device was used in every children. Sixty three children from 12-36 months were included in this study. They were divided into two groups, in the first one, 36 children have had their teeth brushed by their own mothers and in the other group (27 children), the oral hygiene was carried out by a pediatric dentist. The evaluation was performed by only one professional, using the Quigley \& Hein plaque index, before and after the oral hygiene, it was used a plaque disclosing solution (Malachite green 0,6\%). Every tooth with more than half of its crown erupted was evaluated. To evaluate the results, the groups were subdivided in: anterior subgroup (babies with just anterior teeth erupted) and posterior subgroup (babies with at least two posterior teeth erupted). Babies behavior was also evaluated during the hygiene. The results showed that the conventional toothbrush Dental Prev Baby was the most effective in plaque removal in both groups. In the anterior subgroup an equivalent plaque removal was seen when diaper and gauze were used. The less removed plaque quantity was observed with the finger toothbrush Infa-Dent. The oral hygiene performed by the pediatric dentist showed to be more effective than that performed by the mothers. There was no significant difference between the devices used, but it improved along the visits. Concerning the performed 
methodology, we can conclude that: in spite of plaque removal effectiveness promoted by gauze and diaper in babies with only anterior teeth, the conventional toothbrush showed to be more effective in both groups. 